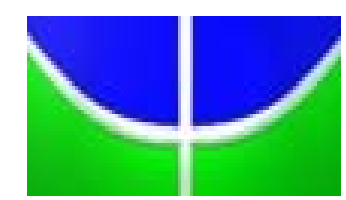

Universidade de Brasília

CET - Centro de Excelência em Turismo

Pós-graduação Lato Sensu

Curso de Especialização em Formação de Consultores em Turismo

\title{
MINIMIZAR RISCOS E AMPLIAR RESULTADOS \\ EM TURISMO DE EVENTOS: DIRETRIZES BÁSICAS \\ PARA PROFISSIONAIS DA ÁREA
}

Ana Paula Kurashima Sobue

Martha Patrícia Gamarra

Brasília (DF), novembro de 2005 
Universidade de Brasília

CET - Centro de Excelência em Turismo

Curso de Especialização Formação de Consultores em Turismo

\title{
MINIMIZAR RISCOS E AMPLIAR RESULTADOS EM TURISMO DE EVENTOS: DIRETRIZES BÁSICAS \\ PARA PROFISSIONAIS DA ÁREA
}

\author{
Ana Paula Kurashima Sobue \\ Martha Patrícia Gamarra
}

Domingos Spezia, M. Sc.

$\overline{\text { Joana D'Arc Bicalho Félix, }}$

M.Sc.

Professor Coordenador

Professora Orientadora
Nome
Professor Examinador

"Trabalho apresentado em cumprimento às exigências acadêmicas parciais do curso de pós-graduação lato sensu em Formação de Consultores em Turismo para a obtenção do grau de Especialista" 
Sobue, Ana Paula Kurashima

Gamarra, Martha Patrícia

Minimizar riscos e ampliar resultados em turismo de eventos : diretrizes básicas para profissionais da área I Ana Paula Kurashima Sobue e Martha Patrícia Gamarra. Brasília, 2005.

$95 \mathrm{f}$. :il.

Monografia (especialização) - Universidade de Brasília, Centro de Excelência em Turismo, 2005.

Orientador: Joana D’Arc Bicalho Félix, M. Sc.

1. Turismo de Eventos. 2. Riscos em Eventos. 3. Gerenciamento de Riscos. 
DEDICATÓRIA

Dedicamos este trabalho a todas as pessoas maravilhosas, presentes e ausentes, que fazem e fizeram parte do crescimento pessoal e profissional de nossas vidas. 


\section{AGRADECIMENTOS}

Aos nossos pais e famílias, que sempre estão presentes nos momentos mais importantes de nossas vidas e são um exemplo de amor.

À Professora Joana Bicalho, CET/ UnB, nossa orientadora, pela oportunidade, ensinamentos e força durante todo o processo.

A todos os nossos amigos, colegas, marido e namorado que participaram nessa viagem do aprendizado. 
"Se uma pessoa entrar em um ramo de negócios tendo como único objetivo juntar dinheiro são grandes as chances de que não conseguirá. Mas, se colocar os serviços e a qualidade em primeiro lugar, o dinheiro cuidará de si mesmo". 


\section{RESUMO}

A atividade turística tem gerado análises e pesquisas tanto nos órgãos oficias, como nos setores produtivos e acadêmicos do mundo. No Brasil, o crescimento do turismo de eventos destaca-se na cadeia produtiva turística, o qual gera milhões de empregos, entre diretos e indiretos. Brasília, por se tratar de uma cidade que acolhe segmentos e nações diversas, sede de órgãos governamentais e que possui boa infra-estrutura, tem a vocação nata para o oferecimento de eventos especiais. Este grande potencial para sediar eventos justifica ainda mais a importância que se deve ter na formação dos profissionais da área, a qual deve ser levada em conta na hora de elaborar e oferecer um serviço com qualificação e excelência. A presente pesquisa demonstra a dificuldade que os gestores de eventos de Brasília encontram em seguir as orientações e referências teóricas. Estes profissionais optam por utilizar manuais próprios, que muitas vezes não percorrem todas as fases e itens que garantem o correto gerenciamento de riscos, ou mesmo não exploram outros procedimentos, utilizando apenas o Check-list, instrumento importante, mas insuficiente para garantir o sucesso de um evento. O trabalho demonstra, também, quais são os principais pontos conflitantes entre a prática realizada e os procedimentos teóricos recomendados, mostrando a necessidade de se identificar cada elemento do planejamento de eventos para realizar o gerenciamento de riscos, minimizando-os. Como acréscimo, propõe-se um Manual Prático para Gerenciamento de Riscos, baseado nas necessidades pesquisadas, propondo procedimentos que poderão favorecer aos gestores. Este manual tem como elemento inovador a inclusão do ciclo PDCA e da Análise SWOT, que trabalhadas simultaneamente, servirão como norteadoras das atividades visto que as empresas de turismo de Brasília não estão acostumadas ou preparadas para trabalhar com mega eventos.

1. Turismo de Eventos 2. Riscos 3. Gerenciamento de Riscos 


\begin{abstract}
The tourism industry has generated research and studies, into government agencies, the private sector, and academic institutions worldwide. In Brazil, the growth of eventbased tourism, in which million direct and indirect jobs have been created, has gained prominence in this profitable industry. Brasília, the seat of the federal government, and a modern, well-developed city of cultural and international diversity, is ideally suited for the hosting of special events. For this reason, it is important that attention be given to the training of tourism professionals in Brasília, particularly as it relates to creating and delivering quality services. This research demonstrates the difficulties that event coordinators in Brasília experience in going "by the book." These professionals opt for using their own manuals, which often do not cover all the steps and details necessary for good risk management, or they prefer to use only a checklist. Checklists are important, but they are not sufficient to guarantee the success of an event. This study also reveals the chief discrepancies that arise between recommended, theoretical procedures and the work that is actually done, underscoring the need to identify each potential problem in the planning of events, in order to better manage-and minimize-risks. Consequently, we have developed a hands-on, risk-management manual based on trial and error for the benefit of event coordinators. This innovative, step-by-step manual includes the PDCA Cycle and SWOT Analysis which, applied simultaneously, will better prepare tourism professionals for planning mega events in Brasília.
\end{abstract}

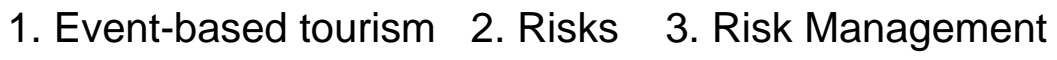




\section{S U M Á RIO}

RESUMO

ABSTRACT

LISTA DE FIGURAS

LISTA DE TABELAS

LISTA DE SIGLAS, SÍMBOLOS E ABREVIATURAS

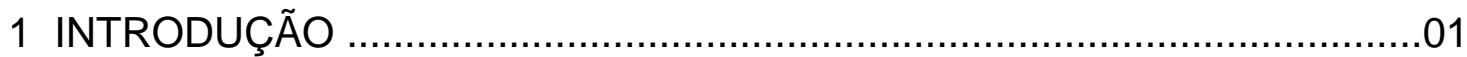

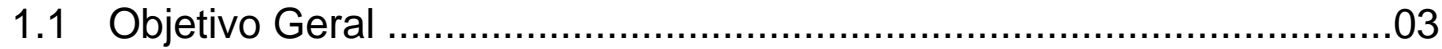

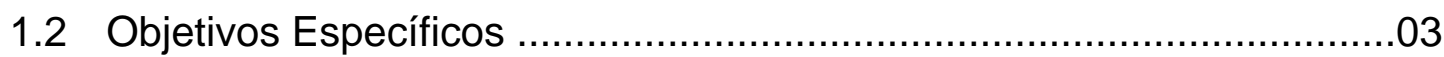

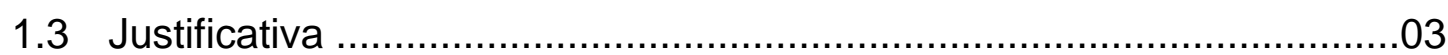

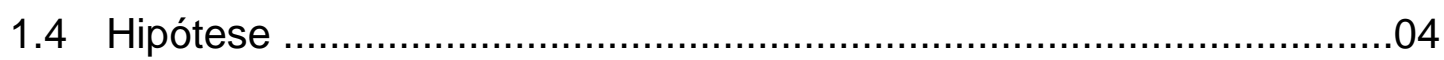

1.5 Metodologia .......................................................................... 05

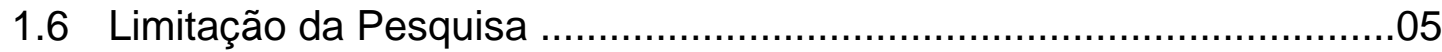

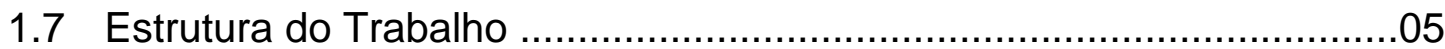

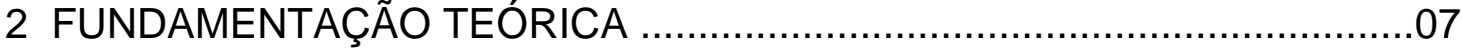

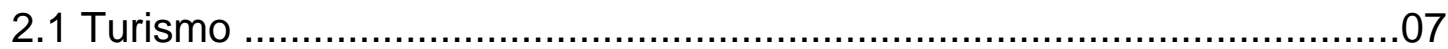

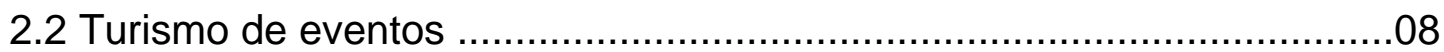

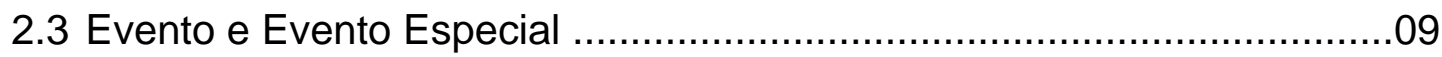

2.4 Riscos em Eventos Especiais .....................................................

2.5 Gerenciamento de Riscos em Eventos ..........................................12

2.6 O Ciclo PDCA e a Análise SWOT como Ferramenta .............................16

2.6.1 Ciclo do PDCA - Facilitando o Processo ....................................16

2.6.2 Análise SWOT - Uma Explicação sobre a Ferramenta ..................18

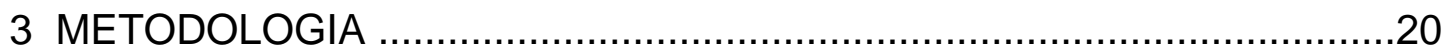

3.1 Técnicas de Pesquisa ...............................................................20

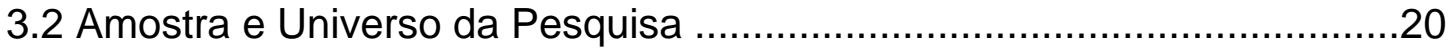

3.3 Instrumentos de Coleta de Dados ..................................................21

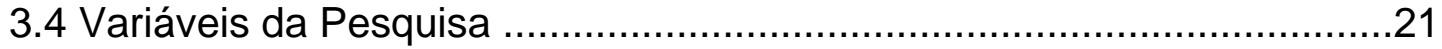

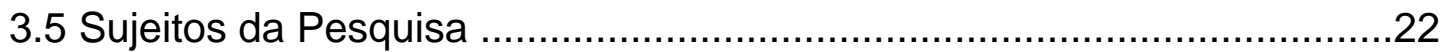

4 APRESENTAÇÃO E ANÁLISE DOS DADOS DA PESQUISA ...................23

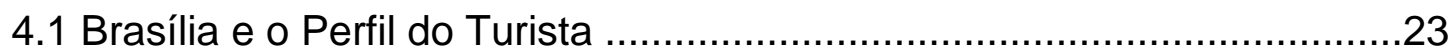

4.2 Turismo de Eventos na Capital do país ...........................................25

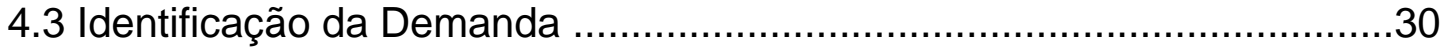


4.4 Práticas gerenciais na Indústria de Eventos de Brasília 32

5 MANUAL PRÁTICO PARA GESTÃO

5.1 Passos no Gerenciamento de Riscos ........................................4

5.2 Roteiro Resumido do Manual Prático ...............................................67

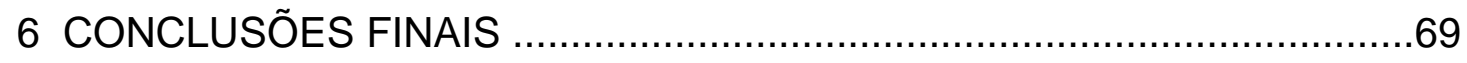

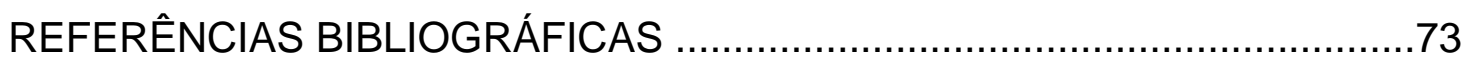

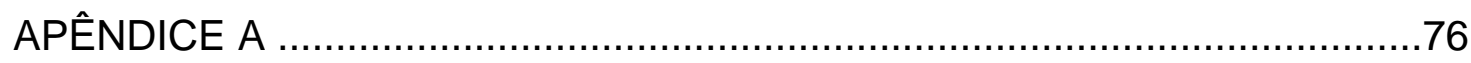

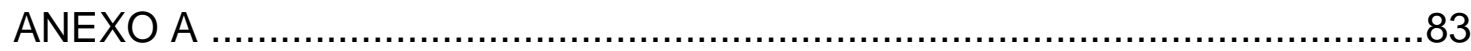




\section{LISTA DE FIGURAS}

1 Relação de Eventos Captados por Região-Brasil .................................08

2 Relação dos Fatores de Risco mais Importantes da Pesquisa ..........................11

3 Motivo da Vinda de Turistas à Brasília ...................................................18

4 Mercado Externo do DF e suas Potencialidades ........................................24

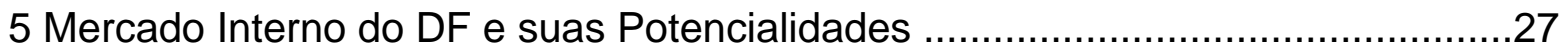

6 Mercado Regional do DF e suas Potencialidades .......................................27

7 Experiência de Trabalho dos Profissionais Entrevistados ................................28

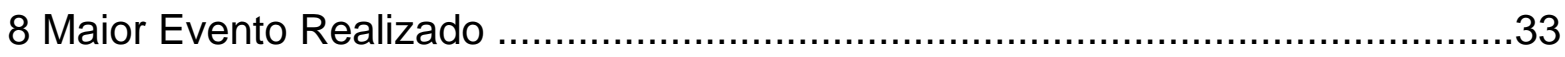

9 Pré-Requisitos para Organização de um Evento ........................................34

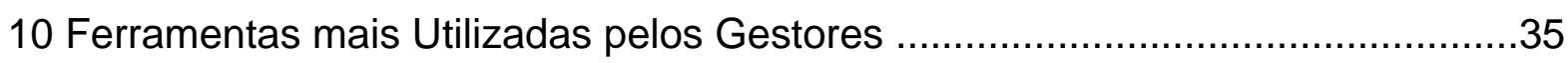

11 Ferramentas Mais Conhecidas e Utilizadas no Gerenciamento .......................36

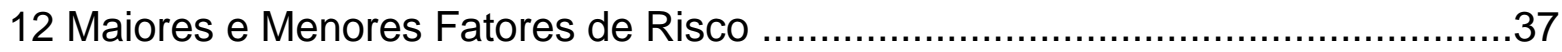

13 Eventos Realizados que não Alcançaram o Sucesso Esperado .......................38

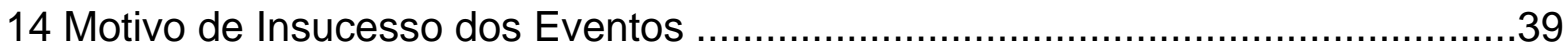

15 Registro de Feedback com o Cliente .....................................................40

16 Registro de Feedback com a Equipe de Trabalho ......................................41

17 Tipo de Seleção da Equipe de Trabalho .............................................41

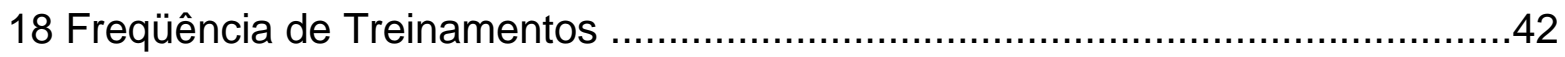

19 Freqüência de Improvisação ..................................................................43

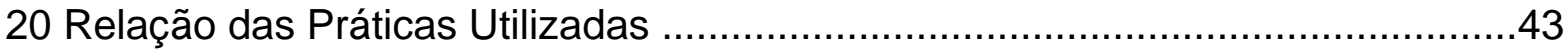

21 Classificação dos Eventos de Brasília .........................................................44

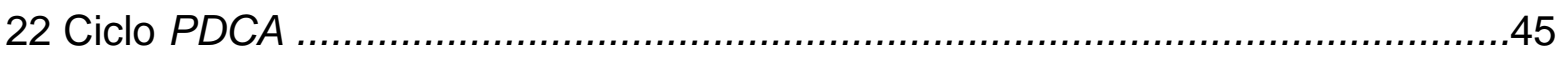

23 Matriz de Classificação de Risco por Probabilidade-Impacto ...........................52

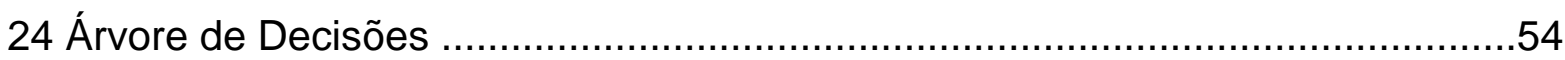




\section{LISTA DE TABELAS}

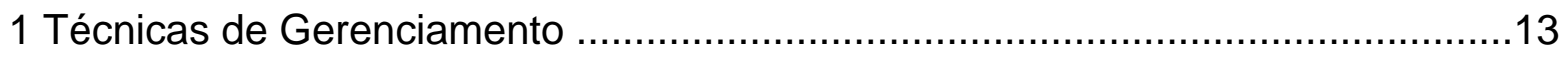

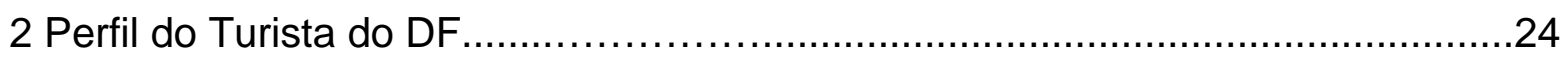

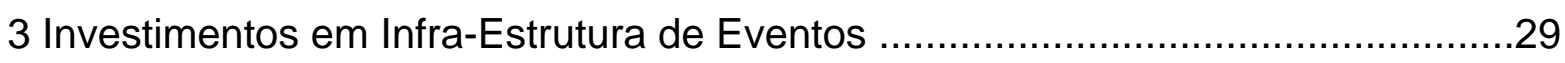

4 Demandas Existentes no DF..........................................

5 Demandas e Respectivas Ações......................................... 31

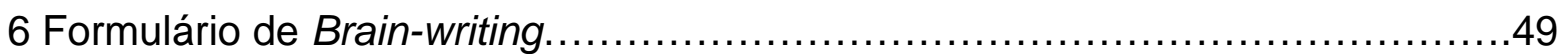

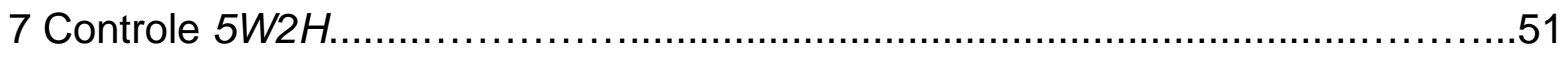

8 Formulário Prático para Classificação de Risco........................................53

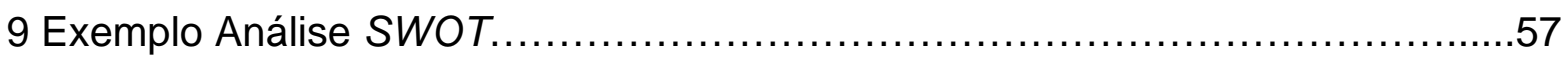

10 Exemplo de formulário para Análise SWOT ...............................58

11 Exemplo Lista de Atividades de uma Olimpíada............................60

12 Exemplo da Tabela de Atividades e Precedências............................61

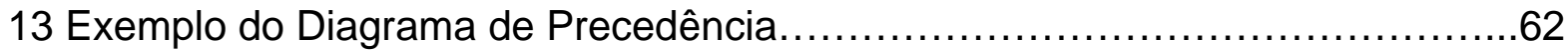

14 Exemplo da Análise do Campo de Forças....................................65

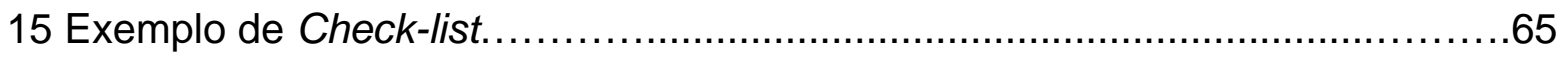

16 Roteiro Resumido do Manual Prático...................................................68 


\section{LISTA DE SIGLAS, SÍMBOLOS E ABREVIATURAS}

$5 W 2 H$ Why, Who, When, Where, What, How, How Much ABEOC Associação Brasileira de Empresas de Eventos

CCR Centro Cultural da República

DF Distrito Federal Instituto Brasileiro de Turismo

FENIT Feira Nacional da Indústria Têxtil

GDF Governo do Distrito Federal $\mathrm{JK}$ Juscelino Kubistcheck

OMT Organização Mundial de Turismo $P D C A$ Plan, Do, Control, Action

PIB Produto Interno Bruto

PNT Plano Nacional de Turismo

SEBRAE Serviço Brasileiro de Pequenas e Médias Empresas SETUR Secretaria de Turismo SWOT Strengths, Weaknesses, Opportunities and Threats VIP Very Important Person 


\section{INTRODUÇÃO}

A inclusão do turismo como indústria capaz de alavancar o crescimento econômico e gerar empregos já é realidade. As análises macro-econômicas da Organização Mundial de Turismo - OMT (2004) reportam que as atividades de viagem e turismo ocupam o primeiro lugar na geração de empregos e na de renda no Produto Interno Bruto - PIB mundial. Vista sob o prisma de uma indústria de turismo, esta se compõe por uma gama de empresas distintas que oferecem serviços intrinsecamente relacionados, de modo que a deficiência de um compromete a existência e o desenvolvimento das atividades correlacionadas.

O efeito multiplicador que compreende as atividades turísticas estabelece o fator determinante de segmentar o mercado, o qual busca as características do mercado-alvo para oferecer bens e serviços específicos. Desta forma, foram estabelecidas as influências turísticas, dentro das quais encontramos, entre muitas outras, o turismo de eventos, que reúne um conjunto de atividades impulsoras como: congressos e seminários, exposições, convenções, feiras, shows e eventos esportivos.

Neste sentido, o turismo de eventos é um ramo que cresce exponencialmente dentre as diversas modalidades de turismo. No Brasil, esse mercado nasceu nos anos 50 com a Feira Nacional da Indústria Têxtil - FENIT, por Caio de Alcântara Machado, realizada pela primeira vez em agosto de 1958, reunindo noventa e sete expositores, iniciando, assim, as grandes mostras industriais e comerciais do país. Segundo a Secretaria de Turismo de Brasília - SETUR (1999-2002), o turismo de eventos propicia gastos per capita / dia de 240 dólares: três vezes mais do que se gasta com o turismo de lazer.

Conforme dados coletados pela OMT (2004), o segmento de eventos mundial tem crescido $12 \%$ ao ano, com a realização de cerca de setenta mil congressos, dos quais o Brasil participa com uma fatia de dois mil desses eventos. Dados resultantes de uma pesquisa realizada pelo Serviço Brasileiro de Pequenas e Médias Empresas - SEBRAE em parceira com o Instituto Brasileiro de Turismo - EMBRATUR (2004) mostram a representatividade do turismo de eventos para o PIB brasileiro, com a 
ocupação dos equipamentos turísticos em $50 \%$ da capacidade e geração de 3 milhões de empregos, entre diretos e indiretos.

Considerando-se a importância da atividade turística de eventos no mundo e no Brasil, Brasília, Capital da República, localizada no centro do país, destaca-se em relação à procura. Segundo dados da SETUR (1999-2002), 76\% da entrada de turistas na cidade está relacionada a negócios, eventos e convenções, o que confirma a vocação da capital para o turismo de eventos. Um ponto forte que a cidade apresenta é a sua representatividade política perante o país e o mundo. $O$ governo iniciou uma série de políticas estratégicas para incrementar esta modalidade de turismo no Distrito Federal - DF. Dentre elas, citam-se o Plano Nacional do Turismo - PNT (2003-2007) com metas de gerar cerca de 1.200 .000 empregos diretos e indiretos, aumento do número de turistas estrangeiros e geração de US\$ 8 bilhões em divisas, além do investimento em infra-estrutura de apoio; a Lei Geral do Turismo; propostas com o objetivo de ampliação da oferta turística; a dedicação da Embratur ao desenvolvimento de um plano estratégico voltado para a promoção internacional do país; o aumento no volume de recursos no Orçamento da União para investimentos na capital; entre outros. A aplicação dessas verbas pode ser identificada na melhoria dos equipamentos como a revitalização do Centro de Convenções, a construção da Ponte JK com arquitetura monumental e arrojada e o início da construção do projeto original da Esplanada em que estão sendo construídos, no centro do poder, o museu, a biblioteca pública, os cinemas, os centros musicais e afins.

Diante desse quadro, nota-se um aumento acelerado da demanda por eventos, de empresas captando as oportunidades e, conseqüentemente, crescente probabilidade de riscos em eventos, no que se refere à prestação de serviços. Outros fatores que exercem pressão sobre os riscos em eventos são os planejamentos precários, a falta de comunicação, o desencontro de objetivos, o número reduzido de referências bibliográficas para pesquisa e a falta de profissionalismo.

Um dos motivos para a escolha desta temática é fornecer um roteiro prático onde serão estabelecidas diretrizes iniciais, básicas e elementares, para minimizar 
os desafios que os riscos impõem sobre um evento. Esses existem, estão em constante alteração e podem criar obstáculos impedindo o alcance da visão estabelecida. Se os riscos forem gerenciados com habilidade e se essas diretrizes forem consideradas pela equipe, desde o estabelecimento da visão, o resultado do evento resultará em sucesso.

\subsection{Objetivo Geral}

Avaliar se o mercado de eventos em Brasília possui ferramentas para minimizar riscos e ampliar resultados, com vistas a atender o ascendente segmento turismo de eventos.

\subsection{Objetivos Específicos}

i) Diagnosticar as técnicas em uso pelos gestores de eventos em Brasília, estabelecendo um paralelo com as referências teóricas aconselhadas;

ii) Compreender os principais riscos em eventos detectados neste mercado;

iii) Propor diretrizes, na forma de um Manual Prático, levando em conta o gerenciamento dos múltiplos riscos, da concepção à realização de um evento, em benefício do turismo de eventos.

\subsection{Justificativa}

A atividade turística representa a maior indústria mundial que gerou cerca de 3,4 trilhões de dólares em atividades econômicas no ano de 2000. Tem participação no PIB brasileiro de 8\%, com uma geração de emprego da ordem de 6,5 milhões nos últimos cinco anos, conforme dados do atual PNT (2003-2007). Constitui-se em um setor expressivo na economia mundial e está, cada vez mais, destacando-se no mercado. 
Entrevistas com profissionais atuantes na cidade de Brasília evidenciam a necessidade de pesquisa aprofundada que defina as principais diretrizes resumidas na forma de um manual, uma vez que justificativas da ausência dessas diretrizes foram apontadas como principais fatores da não observância à gestão dos riscos em eventos. Portanto, os procedimentos reais praticados no cotidiano da realização de eventos demonstram a ausência de diretrizes para a gestão de riscos.

A presente pesquisa apresenta sua importância do ponto de vista científico e inovador no que se refere a turismo de eventos, ao mesmo tempo em que viabiliza instrumentos para que a comunidade local tenha mais segurança em atuar como realizadores de eventos ou mesmo apoiar os eventos que acontecem no DF. Este apoio é de extremo valor, pois um evento contestado pela comunidade devido a questões de: segurança, impacto sobre a localidade, conseqüências de medidas equivocadas dos organizadores, entre outros, pode vir a causar forte impacto negativo para o sucesso do mesmo, podendo comprometer todo o setor de turismo de eventos.

Esta pesquisa facilitará a gestão dos profissionais no que se refere ao planejamento de um evento, servindo como um guia prático, por minimizar as ações desastrosas e considerar a administração de detalhes.

Confirma-se a importância do objeto de estudo o crescimento do mercado de turismo de eventos, o conseqüente aumento da concorrência, a busca pelo sucesso e a exigência cada vez maior dos clientes contratantes. Diante disso, criou-se a necessidade de estabelecer diretrizes que venham minimizar as interferências, facilitando o sucesso dos eventos, apresentadas em manual, ajudando profissionais da área a controlar e minimizar possíveis prejuízos em seus eventos.

\subsection{Hipótese}

Os gestores de eventos em Brasília não utilizam ferramentas que garantem a minimização dos riscos. Dessa forma, não estão preparados para o recente crescimento do mercado do turismo de eventos e necessitam de diretrizes básicas para reduzir os imprevistos e aumentar a segurança. 


\subsection{Metodologia}

A metodologia baseou-se em método exploratório, por meio de pesquisas bibliográficas, com o objetivo de verificar as contribuições atuais existentes acerca do tema abordado; entrevista qualitativa com profissionais da área de turismo e eventos para avaliar a relação risco em eventos de grande porte e as práticas em uso contemporâneo, confrontando teoria e prática. A partir desses resultados, serão propostas diretrizes em um manual prático.

\subsection{Limitação da Pesquisa}

A proposta inicial seria trabalhar em estudo de caso de evento de grande porte no turismo, previsto, inicialmente, para acontecer em Brasília no mês de junho. Foram acompanhados alguns passos da concepção deste evento que, até o mês de outubro, já havia sofrido dois adiamentos na data de realização, devido à falta de patrocínio, apesar de anunciadas as datas pela mídia. A falta de gerenciamento do evento evidenciou a urgência no estabelecimento de diretrizes para minimizar riscos, levando este estudo à abrangência de avaliação do mercado, não mais focando apenas em um estudo de caso.

\subsection{Estrutura do Trabalho}

Na primeira parte do trabalho serão apresentados abordagem da situação do turismo de eventos no Brasil, dados estatísticos da geração de divisas que essa atividade turística proporciona ao país, a origem do turismo e a maneira com que esse ramo se desenvolve. A partir da análise do turismo de eventos no Brasil, a pesquisa se aprofunda na cidade de Brasília, capital federal. Esse foco foi escolhido pelas próprias características vantajosas que a cidade apresenta com relação ao desenvolvimento da atividade do turismo de eventos. São apresentados os objetivos específicos, que devidamente cumpridos, proporcionarão o alcance do objetivo geral descrito nesta. 
A Fundamentação Teórica apresenta a análise de conceitos relacionados ao turismo, a eventos e ao turismo de eventos, bem como ao gerenciamento de riscos. Mostra também a evolução da preocupação com os riscos na realização de eventos.

A segunda parte do trabalho será o aprofundamento do tema, baseado nos resultados das entrevistas realizadas e análises comparativas, entre teoria e prática, com vistas à proposição de diretrizes práticas para realização de eventos, estruturados em planejamento detalhado das atividades com o objetivo de reduzir os riscos. Apresenta também as etapas para se fazer um bom planejamento e as técnicas apropriadas para este fim, fornecendo aos profissionais da área importante ferramenta de gestão. 


\section{FUNDAMENTAÇÃO TEÓRICA}

\subsection{Turismo}

Segundo a OMT (2005), o turismo compreende as atividades que as pessoas realizam "durante suas viagens e estadas em lugares diferentes ao seu entorno habitual, por um período consecutivo inferior a um ano, com finalidade de lazer, negócios ou outras". Antigamente privilégio das classes dominantes e, na atualidade, uma aspiração de todos os incluídos na sociedade global de consumo, o turismo é hoje um fenômeno social e cultural porque faz parte das necessidades criadas pelo mundo moderno. (Disponível em: <http://www.wtoelibrary.org>. Acesso em: 25 set. 2005).

No início do século $X X$, as viagens de lazer eram privilégio de uma parcela mínima da sociedade, com serviços elitizados e consumidos pela classe alta. Essa atividade foi interrompida pelas duas grandes guerras mundiais e somente no término da Segunda Guerra Mundial, 1945, o fluxo de viagens volta a se reorganizar. No início dos anos 80, o turismo tornou-se o centro das atenções por envolver um grande número de pessoas. Esse período se diferencia ao do anterior à guerra, pois o mundo globalizado permitiu a informação em massa, com o advento da tecnologia e da internet.

A globalização também influenciou o turismo com a abertura de um conjunto de serviços interligados que resultaram na combinação do trabalho de várias empresas de atividades diversas. Firmas inicialmente voltadas para o âmbito de vender ou de servir aos turistas, especializaram-se em segmentos turísticos com vistas a proporcionar melhor atendimento e satisfazer as necessidades. Como a própria definição de turismo expõe, vários são os motivos que levam pessoas a se deslocarem; seja lazer, negócios, religião, estudos, entre outros. Fruto desta segmentação no mercado turístico desenvolveu-se, dentre os muitos segmentos, o de turismo de eventos.

O turismo de eventos é uma modalidade com potencial multiplicador turístico. Diante dessa premissa, é importante conhecer os conceitos teóricos apresentados 
por vários autores da área como base inicial para entender as inter-relações das múltiplas atividades que envolvem esse segmento. Também são apresentadas as atuais contribuições dos estudiosos da área e o comportamento do mercado brasileiro. Dentre as definições, serão destacadas: Turismo de Eventos, Evento /Evento Especial e Riscos em Eventos Especiais.

\subsection{Turismo de Eventos}

O turismo de eventos é o responsável por manter as atividades da cadeia produtiva turística, pois a realização do mesmo influencia na diminuição da sazonalidade turística de uma região, bem como estabelece uma imagem positiva da cidade sede. O desenvolvimento dessa atividade movimenta os vários setores da economia local, propicia emprego, renda e possibilita a acumulação de divisas para cidade, estado e país.

Dos 330.000 eventos realizados no ano de 2001, em todo o Brasil, conforme mostra a FIGURA 1, foram realizados 52\% nos estados do Sudeste, principalmente em São Paulo. Na região Sul foram realizados 19\%; enquanto no Nordeste e Centrooeste foram sediados $18 \%$ e $11 \%$ da fatia, respectivamente.

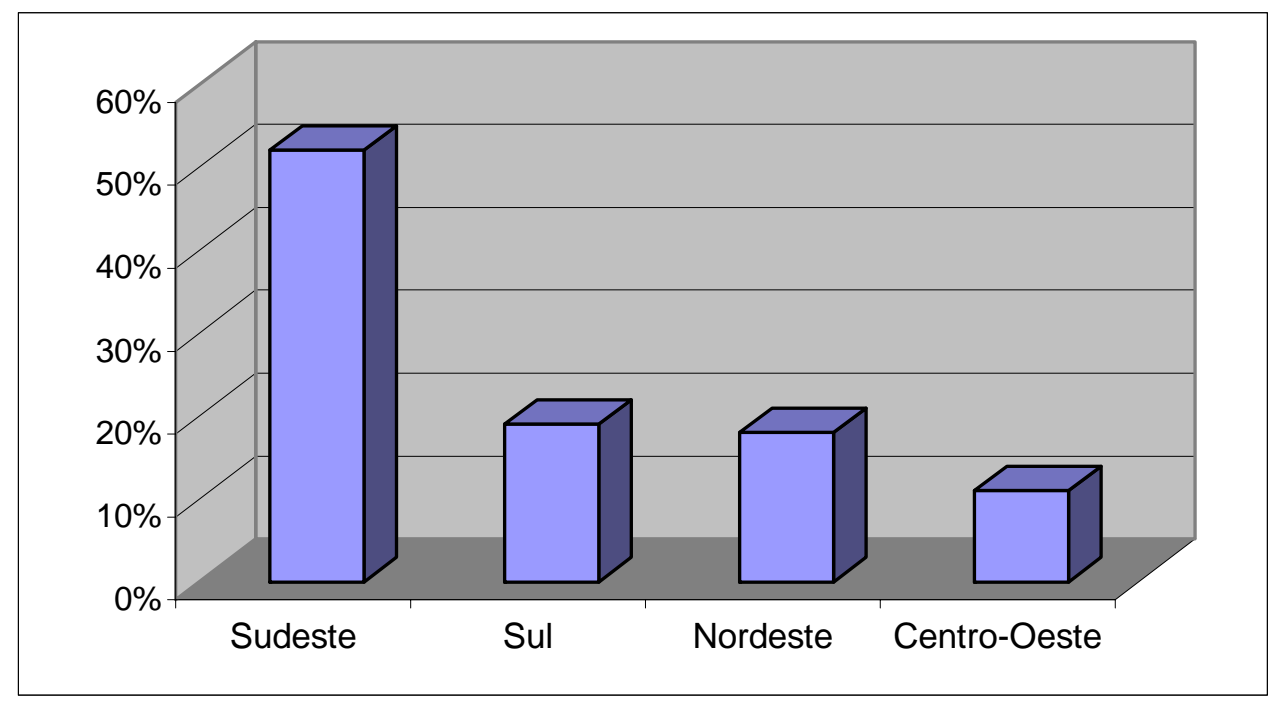

Figura 1: Relação de Eventos Captados por Região-Brasil

Fonte: Disponível em: <http://www.ba.sebrae.com.br>. Acesso em: 13 jul. 2005. 
Segundo dados da $1^{\circ}$ Pesquisa sobre o dimensionamento econômico do turismo de eventos no Brasil realizada pelo Serviço Brasileiro de Pequenas e Médias Empresas - SEBRAE (2001), o turismo de eventos é um setor que está crescendo aceleradamente e possui notável expressividade, como demonstram os dados abaixo:

-No Brasil já existem 1.780 espaços para realização de eventos;

-Mais de 79,9 milhões de participantes;

-Movimenta uma renda total de $\$ 37$ bilhões;

-Possui 3,1\% de participação no Produto Interno Bruto;

-Gera $\mathrm{R} \$ 4,1$ bilhões de tributos;

-Permite o investimento médio de $\mathrm{R} \$ 392,05$ por turista participante de eventos;

Além dos representativos e crescentes dados acima, o turismo de eventos contribui em muito para o incremento da atividade turística em períodos importantes concentrando-se nos meses de agosto a dezembro, e prioritariamente $60 \%$ nos dias de semana. Em virtude do aumento da potencialidade desse segmento, das características apresentadas na pesquisa acima e da vontade de tornar uma cidade um pólo de turismo de eventos, governo e iniciativa privada das mais diversas cidades têm investido em infra-estrutura para acolher o maior número de eventos possíveis. Foi o caso da construção do primeiro centro de eventos da América Latina, o Cau Hansen em Joinville - SC, que se utiliza de arenas multiuso, versáteis e funcionais. A origem da configuração do seu espaço foi o picadeiro dos circos, palco dos grandes espetáculos e manifestações artísticas oferecendo multifuncionalismo em seu empreendimento. Esse fato posiciona a cidade de Joinville dentro do limitado mercado de grandes eventos e reforça o poder econômico e influência que a mesma exerce no estado.

\subsection{Evento e Evento Especial}

Conforme sinaliza Goldblatt (1997), "todas as sociedades humanas celebram suas alegrias, suas tristezas e triunfos com cerimoniais e rituais". Inicialmente destinados a comemorar atos religiosos, políticos e cívicos, as festas sempre 
mantiveram seu caráter alegre. Originado do Latim eventus, atualmente, os eventos podem ser classificados como culturais, esportivos, musicais, inaugurativos, comemorativos, datas cívicas, congressos, convenções, feiras, exposições, seminários, entre outros. A partir desses, surgem situações diferenciadas que caracterizam os eventos especiais. Para Goldblatt (1997), evento especial é "um momento único no tempo de celebrar com cerimoniais e rituais que satisfazem uma necessidade específica". Desta forma, constata-se que um evento especial é algo diferente da vida rotineira que precisa ser detalhadamente programado com vistas a manipular todo o processo de planejamento, de gerenciamento e de coordenação.

Algumas circunstâncias são comuns no ramo de eventos. Os Oscares de filmes, as Olimpíadas, o carnaval do Rio de Janeiro, a Copa do Mundo, entre outros, são eventos que englobam multidões e envolvem atividades complexas. Geralmente são constituídos de atividades que envolvem situações de perigo, organizadores sem experiência, muitas vezes voluntários inexperientes ou equipe pouco qualificada, locais temporários, falta de relações comunitárias estabelecidas e comunicação precária, ausência de registros de eventos anteriores e acontecimentos inéditos, questões de segurança, eventos internacionais de culturas diferentes ou decisões de última hora.

\subsection{Riscos em Eventos Especiais}

Em linhas gerais, os riscos são situações que podem ocorrer, trazendo impactos de ameaças com conseqüentes danos. Os autores Schwartz, Yaffe, Goldblatt e Silvers (2000) conceituam risco como "uma expectativa de perda expressada como a probabilidade de que uma ameaça em particular poderá explorar uma vulnerabilidade como um possível prejuízo". De acordo com Schwartz, et. al. (2000), "a incerteza ou falta de informações é a mãe do risco e, enquanto profissionais, é nossa responsabilidade minimizá-los".

Nesse contexto, foi realizada uma pesquisa organizada pela The Association for the Advancement of Cost Engineering - AACE, por sua Comissão Internacional de Gestão de Riscos e Decisões Gerenciais, nos Estados Unidos da América, junto a cem eventos. O objetivo dessa pesquisa foi entender o que os profissionais da 
área de turismo de eventos pensavam sobre o conceito de risco. Ao final, os entrevistados concluíram que risco é uma função que envolve incertezas, ameaças e oportunidades. Concluíram, também, que as ameaças são circunstâncias que afetam os resultados do evento, as oportunidades ajudam nos resultados e a incerteza é um conjunto de aspectos positivos e negativos impactantes em um evento.

Identificar os maiores fatores de risco particularmente por evento é muito mais importante e útil do que tentar desenvolver os fatores genéricos para todos os eventos. Uma vez que os eventos possuem suas particularidades e objetivos, não é recomendável generalizar esses riscos, pois cada um demanda um planejamento específico e por isso, apresenta fatores e conseqüências distintas. É certo que alguns fatores de riscos são gerais e aplicados em qualquer tipologia de evento como comunicação ineficiente, planejamento às pressas, planejamento e gerenciamento inadequado, erros individuais e condições físicas do local do evento impróprias.

Segundo pesquisa realizada pela Universidade George Washington EUA (2000) junto a 396 pessoas, foram identificados, conforme mostra a FIGURA 2, os dez mais importantes fatores de riscos para qualquer tipo de evento.

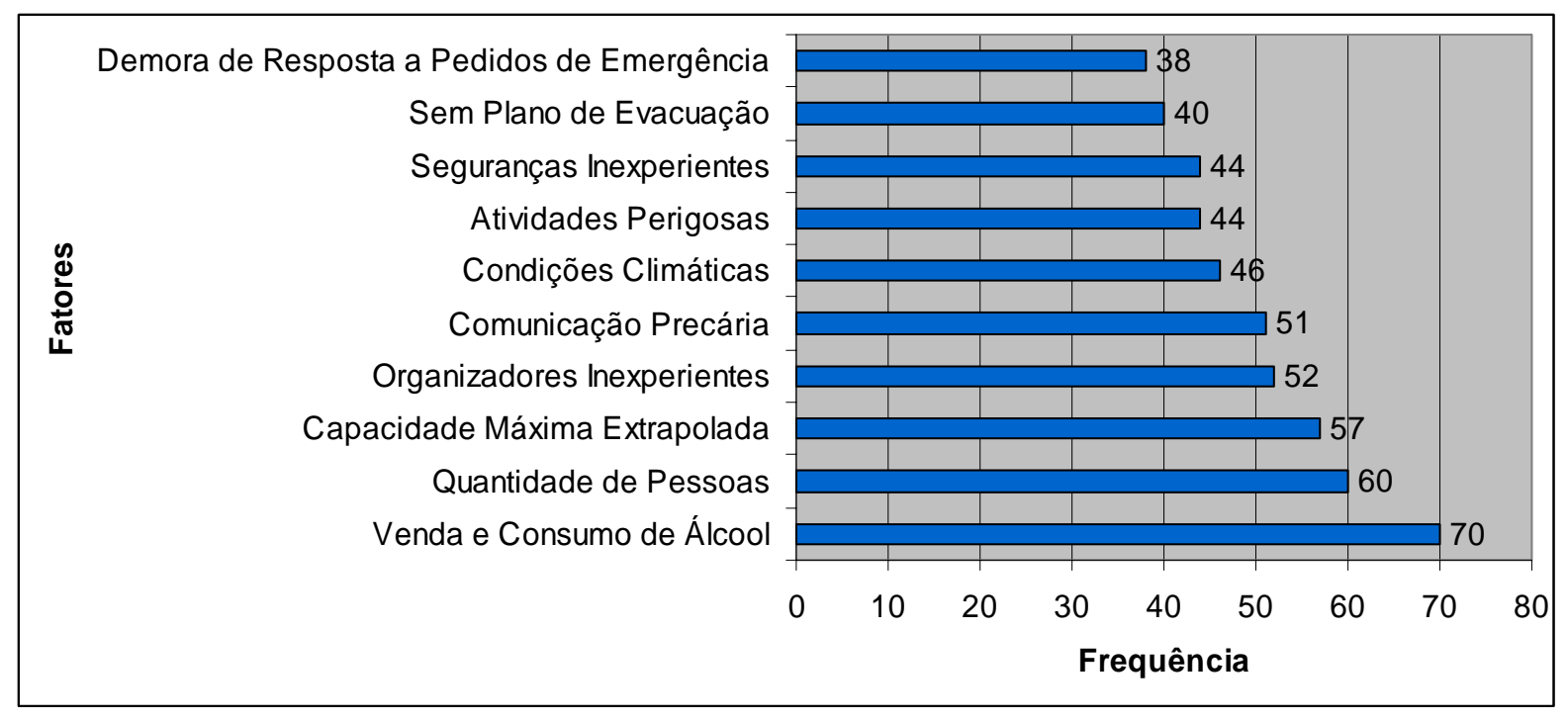

Figura 2: Relação dos fatores de risco mais importantes da pesquisa 
Fonte: Schwartz; Yaffe; Goldblatt; Silvers. Risk Management: Financial, Legal and Ethical Safeguards. The George Washington University Workbook. Washington: School of Business and Public Management, 2000.

Desta forma, vários são os motivos de riscos apontados pela pesquisa.

Diante da pesquisa realizada, comprova-se que a maior preocupação dos profissionais de eventos, nos Estados Unidos, é a venda e o consumo de álcool, seguida da quantidade de pessoas e da capacidade máxima extrapolada. Por sua vez, os fatores menos freqüentes foram a demora de resposta a pedidos de emergência e a ausência de plano de evacuação.

\subsection{Gerenciamento de Risco em Eventos}

A prática de Gerenciar origina-se nas Teorias da Administração de Henri Fayol, que foi o pioneiro na definição da administração, como processo de planejar, organizar, dirigir e controlar. Goldblatt (1997, p.129) afirma que a diferença entre gerenciar e liderar "caracteriza-se por uma simples, mas efetiva definição que gerentes controlam problemas, enquanto líderes motivam a equipe para alcançar as metas". A responsabilidade do gerente é desenvolver as políticas, os procedimentos e as práticas do evento, assim como estimular liderança, realizar treinamentos, apresentar ferramentas para a equipe e estabelecer objetivos gerais.

Segundo Schwartz, et. al. (2000, p.28), gestão de riscos é "um processo complexo, interativo e dinâmico de tomada de decisões sobre a utilização de recursos os quais requerem uma análise efetiva e estratégica durante o processo de produção de um evento". Portanto, gerenciar riscos consiste em gerenciar incertezas, as quais são identificadas e priorizadas, com o objetivo de desenvolver planos de ação para integrar as atividades na realização de um evento.

Para se obter o sucesso de um evento, é necessário que os gestores e colaboradores estejam comprometidos e familiarizados com o planejamento e procedimentos definidos. É importante trabalhar com uma equipe coesa, devidamente treinada e qualificada para desempenhar as funções. O processo de 
tomar decisões, parte fundamental do trabalho de administradores, faz-se imprescindível para analisar e enfrentar problemas, assim como, aproveitar oportunidades. Compreender e ter domínio de todo o processo operacional e administrativo com atenção voltada a especificidades organizacionais reduz possíveis perdas e danos.

Portanto, diversas técnicas foram desenvolvidas para ajudar os profissionais nesse aspecto. Além das técnicas, existem os princípios e recomendações sobre como proceder no processo de análise de problemas e tomada de decisões. Alguns são aplicados a problemas específicos, como por exemplo, na administração da qualidade. Os demais podem ser utilizados em quaisquer circunstâncias. Esses recursos ajudam a estruturar o processo decisório, elevando o grau de racionalidade e veracidade, além de eliminar o improviso a fim de diminuir a probabilidade de erros.

Os estudiosos já desenvolveram várias técnicas alternativas que facilitam o gerenciamento de um evento onde são apresentados os conceitos na TABELA 1. São técnicas como o Brainstorming, o Brain-writing, o 5W2H, o Check-list, a Matriz de Classificação de Risco por Probabilidade, a Tabela de Atividades e Precedências, o Diagrama de Precedências, a Análise de Vantagens e Desvantagens, a Árvore de Decisões, a Análise do Campo de Forças, a Ponderação de Critérios, o Ponto de Equilíbrio e a Análise de Desempenho.

TABELA 1

TÉCNICAS DE GERENCIAMENTO

\begin{tabular}{|l|l|}
\hline \multicolumn{1}{|c|}{ FERRAMENTA } & \multicolumn{1}{c|}{ CONCEITO } \\
\hline $\begin{array}{l}\text { Brainstorming } \\
\text { (tempestade de idéias) }\end{array}$ & -É um processo em que se tem a capacidade de otimizar e gerar um \\
número grande de novas idéias com o propósito de identificar e \\
entender a situação analisada para encontrar o problema ou solução. \\
-"É um técnica utilizada em reuniões por grupos que tentam encontrar \\
uma solução específica a um problema em que se manipulam todas as \\
idéias espontâneas". \\
Disponível em:<http://www.brainstorming.com.uk/tutorials/definitions>. \\
Acesso em: 13 ago. 2005.
\end{tabular}




\begin{tabular}{|c|c|}
\hline $\begin{array}{l}\text { Brain-writing } \\
\text { (tempestade de idéias } \\
\text { escritas) }\end{array}$ & $\begin{array}{l}\text {-O objetivo é realizar um diagnóstico perceptivo para produzir um } \\
\text { conjunto de idéias, percepções e opiniões, por escrito, abrangendo um } \\
\text { grande número de pessoas, as quais contribuirão com experiências } \\
\text { específicas e inovadoras para uma determinada situação. } \\
\text {-Processo realizado em um período de tempo curto com posterior } \\
\text { possibilidade de análise dos dados levantados. } \\
\text { Disponível em:<http://www.brainwriting.com.uk>. Acesso em: } 13 \text { ago. } \\
2005 \text {. }\end{array}$ \\
\hline $\begin{array}{l}5 W 2 H \\
\text { (WHAT, WHERE, WHEN, } \\
\text { WHO, WHY, HOW, HOW } \\
\text { MUCH) }\end{array}$ & $\begin{array}{l}\text {-São sete palavras em inglês, sendo cinco delas iniciadas com W e } \\
\text { duas, com H. Consiste em técnicas participativas que permitem } \\
\text { opções de melhoria /modificação em situações propostas de solução } \\
\text { ou preparação de um evento, técnica proposta por Goldblatt (1997). } \\
\text {-Sua vantagem é a definição objetiva e clara de todos os itens que } \\
\text { compõem um planejamento. É necessário estar preparado para fazer } \\
\text { as primeiras perguntas na primeira reunião com a equipe de trabalho. } \\
\text {-É preciso maximizar o tempo, por isso, é importante fazer as } \\
\text { perguntas certas para obter o máximo de informações possíveis. }\end{array}$ \\
\hline Check-lists & $\begin{array}{l}\text {-São listas de verificação cujo suporte também está nas características } \\
\text { e históricos de eventos. } \\
\text {-São confeccionadas de acordo com as necessidades de cada projeto } \\
\text { e de cada setor que participará do evento. }\end{array}$ \\
\hline $\begin{array}{l}\text { Matriz de Classificação de } \\
\text { Risco por Probabilidade } \\
\text { /Impacto }\end{array}$ & $\begin{array}{l}\text {-Heldman (2003, p.169) propõe que a matriz é desenvolvida para } \\
\text { classificar os riscos em altos, médios ou baixos. } \\
\text {-A avaliação consiste em verificar a probabilidade de um risco ocorrer; } \\
\text { assemelha-se ao exemplo clássico da moeda, em que se tem } 50 \% \text { de } \\
\text { sair "cara" e } 50 \% \text {, "coroa", somando-se } 100 \% \text {, o equivalente ao } \\
\text { número } 1 \text { (um). O mesmo ocorre nessa matriz, a escala de } \\
\text { probabilidade inicia em } 0,0 \text {, que indica nenhuma probabilidade de } \\
\text { ocorrência e finaliza em } 1,0 \text {, que representa } 100 \% \text { de ocorrência } \\
\text { daquele risco. } \\
\text {-Com relação ao impacto de cada risco apontado anteriormente, } \\
\text { atribuem-se valores numéricos reais. } \\
\text {-De posse desses dados, os responsáveis analisam a situação e } \\
\text { dessa forma, todos os riscos serão listados e priorizados com base na } \\
\text { classificação dos riscos e em outros fatores. } \\
\text {-A avaliação da probabilidade e do impacto dos riscos, normalmente, é } \\
\text { realizada por meio de avaliação por especialistas, entrevistas, } \\
\text { brainstorming, entre outras. }\end{array}$ \\
\hline $\begin{array}{l}\text { Tabela de Atividades e } \\
\text { Precedências }\end{array}$ & $\begin{array}{l}\text {-Técnica proposta por Maximiano (2000) em que se agrupa uma } \\
\text { seqüência de atividades com a indicação da duração e da seqüência }\end{array}$ \\
\hline
\end{tabular}




\begin{tabular}{|c|c|}
\hline Diagrama de Precedência & $\begin{array}{l}\text { de cada uma delas. } \\
\text {-Em conjunto com a tabela, tem-se o Diagrama de Precedências como } \\
\text { ferramenta de auxílio a qual indica o seqüenciamento e a precedência } \\
\text { das atividades, a duração, permite conhecer os tempos livres, as } \\
\text { folgas e o caminho crítico para a realização do evento. }\end{array}$ \\
\hline $\begin{array}{l}\text { Análise de Vantagens e } \\
\text { Desvantagens }\end{array}$ & $\begin{array}{l}\text { - Para Maximiano (2000) é utilizada no momento em que se precisa } \\
\text { decidir sobre um problema ou possibilidade. Considerando a utilização } \\
\text { desta ferramenta, a partir de informações recebidas, a decisão se } \\
\text { constituirá pela análise dos dados e verificação de situações } \\
\text { vantajosas e desvantajosas ao evento. }\end{array}$ \\
\hline Árvore de Decisão & $\begin{array}{l}\text {-Para Maximiano (2004) esta técnica constitui-se de um diagrama que } \\
\text { mostra a seqüência das decisões inter-relacionadas e os resultados } \\
\text { esperados de acordo com a alternativa escolhida. Geralmente, há } \\
\text { mais de uma escolha disponível ao se deparar em uma situação de } \\
\text { tomada de decisão e, também, há as possíveis conseqüências que } \\
\text { poderão ocorrer ao seguir por aquele caminho. } \\
\text {-As alternativas possíveis são ilustradas em forma de uma árvore } \\
\text { alocada à esquerda, iniciando com a decisão relacionada ao risco e, } \\
\text { ramifica-se para a direita, apresentando a conseqüência. Em geral, } \\
\text { esse tipo de técnica é utilizada para os eventos de risco associados a } \\
\text { tempo e custo. }\end{array}$ \\
\hline $\begin{array}{l}\text { Análise do Campo de Forças } \\
\text { ou Análise SWOT }\end{array}$ & $\begin{array}{l}\text { - Para Goldblatt (1997) consiste na verificação do comportamento } \\
\text { resultante da atuação de duas forças que se opõem: as forças } \\
\text { restritivas, que inibem esse comportamento e as forças propulsoras, } \\
\text { que o estimulam. } \\
\text {-O mecanismo de funcionamento dessa análise é justamente a } \\
\text { observação da intensidade dessas forças, dependendo do peso de um } \\
\text { dos lados, o comportamento será inibido ou estimulado. }\end{array}$ \\
\hline Ponderação de Critérios & $\begin{array}{l}\text {-Nesta técnica proposta por Maximiano (2004), tem-se que a avaliação } \\
\text { de alternativas é submetida a critérios. A utilização da análise por } \\
\text { critérios e pesos, ou seja, dar um valor naquele critério que é mais } \\
\text { importante, faz com que essa verificação seja objetiva, levando-se em } \\
\text { conta as necessidades e objetivos que se pretende chegar. }\end{array}$ \\
\hline Análise do Ponto de Equilíbrio & $\begin{array}{l}\text {-Baseia-se na equação Custo Total (CT) = Custo Fixo (CF) + Custo } \\
\text { Variável (CV). Com essa equação, pode-se estudar o comportamento } \\
\text { dos custos totais, de acordo com as alterações dos custos que o } \\
\text { compõe, o custo fixo e o custo variável. } \\
\text {-Conforme Maximiano (2004), "a Análise do Ponto de Equilíbrio } \\
\text { permite identificar o volume de operações em que as receitas são } \\
\text { equivalentes aos custos totais. Esse é o ponto de equilíbrio, a partir do }\end{array}$ \\
\hline
\end{tabular}




\begin{tabular}{|l|l|}
\hline & qual as receitas superam os custos e a empresa começa a ter lucro". \\
\hline Feedback de Desempenho & -De acordo com Maximiano (2000, p. 189) um outro método dessa \\
& fase é a avaliação do evento, que consiste na avaliação do evento por \\
& parte dos clientes e dos colaboradores que participaram de sua \\
& realização. \\
& -É uma ferramenta de controle pós-evento, muito útil para saber o que \\
& deu certo lerrado, problemas identificados, itens a melhorar e até \\
& mesmo mensurar o grau de satisfação dos clientes. \\
\hline
\end{tabular}

Como se percebe, as técnicas apresentadas são diversas, amplas e complexas, o que dificulta unir a teoria à prática. Essas são algumas ferramentas que podem ser aplicadas. É importante salientar que se podem aplicar quaisquer umas delas de acordo com os objetivos propostos e com a facilidade de uso pela equipe.

\subsection{O Ciclo PDCA e a Análise SWOT como Ferramenta}

Baseadas no referencial teórico e na realidade prática dos gestores, são propostas diretrizes iniciais baseadas em duas técnicas até então abordadas de forma superficial pelos profissionais entrevistados. São elas: o ciclo PDCA e a análise SWOT. Essas duas ferramentas servirão de base para todos os passos do gerenciamento de risco.

Diante dos resultados das pesquisas realizadas e das entrevistas com profissionais da área, propõe-se o ciclo PDCA e a análise SWOT como ferramentas para gerenciar em detalhes os riscos de um evento. Estas duas ferramentas utilizadas em conjunto servirão de base dos processos de gerenciamento de riscos. Desta forma, estamos contribuindo para minimizar as incertezas e controlar de forma efetiva as múltiplas atividades que envolvem a organização de um evento.

\subsubsection{Ciclo do PDCA-Facilitando o processo}

Primeiramente, é importante considerar o Planejamento estratégico, do inglês Plan, como ponto de partida que aborda uma seqüência de análises para determinar um conjunto de atividades necessárias, com o objetivo de definir a missão, os 
métodos, as estratégias e os resultados. A execução do plano, do inglês Do, é a segunda etapa na qual há a aplicação das tarefas previstas no planejamento e quando há a coleta de dados para verificação do processo. No controle das atividades, do inglês, Check, é feita uma comparação do resultado alcançado com a meta esperada a qual deve ser realizada em cada fase do processo, a partir dos dados coletados anteriormente. $E$ as ações corretivas, do inglês Action, é a etapa na qual haverá a identificação de desvios de procedimentos que resultaram em erros ou situações mal resolvidas, portanto, é a fase das correções. Esse ciclo, o PDCA, consiste em um método gerencial de controle de processo para melhoria contínua de resultados.

A organização do evento será baseado nessas quatro etapas do ciclo conforme FIGURA 3. No planejamento estará a definição das metas, a identificação e a análise dos riscos; na execução, a ação de tarefas; no controle, o controle dos riscos e na ação, a correção das atividades. Primeiramente, deve-se fazer o planejamento do evento para depois colocá-lo em prática. Somente durante a sua realização pode-se fazer o controle. Sucessivamente, há a correção daquilo que não resultou como o esperado, finalizando o processo. 


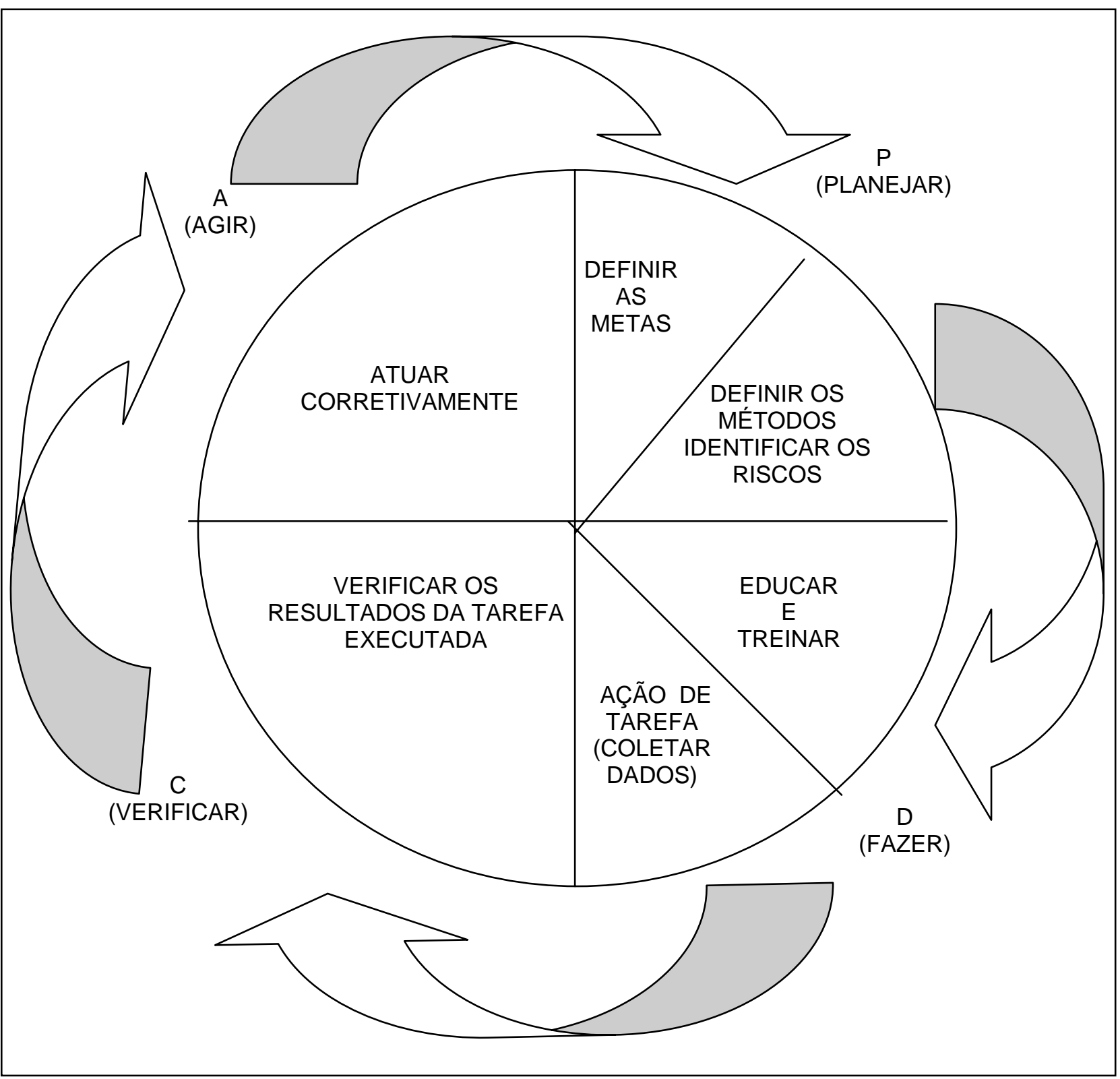

Figura 3: Ciclo PDCA. CAMPOS, Vicente Vicente. TQC: Controle da Qualidade Total (No Estilo Japonês). Belo Horizonte: Fundação Christiano Ottoni, 1992.

\subsubsection{Análise SWOT - Uma Explicação sobre a Ferramenta}

A análise Strenghts, Weaknesses, Opportnities and Threats - SWOT consiste em uma análise para entender e identificar efetivamente as situações propostas. É a segunda ferramenta proposta para atuar no gerenciamento de riscos.

Goldblatt (1997, p. 38) avalia que "na realização de qualquer evento, seja de pequeno ou grande porte, é imprescindível realizar uma avaliação interna e externa 
dos riscos com a utilização da Análise SWOT". Na Análise Interna, mencionam-se os pontos fortes Strengths e os pontos fracos Weaknesses, onde estão as variáveis gerenciáveis da organização, as quais os gestores têm poder de mudança. A identificação das fragilidades permite que haja o estudo dos pontos fracos existentes e a possibilidade de torná-los pontos fortes. E esses, uma vez identificados, faz com que a empresa aproveite os seus diferenciais. Na Análise Externa, com as oportunidades Opportunities e as ameaças Threats, está o estudo onde se define a limitação dos riscos, o qual é fundamental para o planejamento, já que dentro destas características externas existem fatores fora do controle da organização e que estão em freqüente mudança.

A ferramenta da Análise SWOT deve ser utilizada paralelo às etapas do Ciclo PDCA, sendo que em cada uma delas faz-se necessário o direcionamento para a fase na qual se está aplicando este método. A importância desta ferramenta é entendê-la como um mecanismo indispensável em cada etapa do ciclo e não como uma análise isolada no início do planejamento ou somente com relação a análise da concorrência, macroanálise; mas, como uma análise micro, com aplicação em cada departamento envolvido no evento. Quando as outras técnicas são aplicadas com o objetivo de afunilar e de analisar os riscos-imprevistos, esta ferramenta vai agrupar cada elemento identificado no lugar certo da análise, seja interno ou externo. Assim, os cálculos de erros são muito mais mesuráveis e mais gerenciáveis e no caso desses erros acontecerem, não há a necessidade de se tomar decisões apressadas vez que bem gerenciadas, não colocarão em risco o evento. 


\section{METODOLOGIA}

\subsection{Técnicas de Pesquisas}

i) Pesquisa Bibliográfica: pesquisa em livros que abordam o turismo no Brasil e no mundo, a gestão em turismo, bem como livros de administração e livros que tratam de eventos e gerenciamento de riscos em fontes secundárias.

ii) Pesquisa Documental em: revistas, artigos e sites de importantes órgãos da área como Embratur, Secretaria de Turismo do Distrito Federal e Convention \& Visitors Bureau.

Os objetivos nesta fase são compreender a amplitude referencial sobre o aumento da demanda do turismo de eventos, gerenciamento de riscos, planejamento estratégico em turismo, inserção de comunidades no turismo local bem como sobre os roteiros ou check-list de preparação e execução dos eventos ora utilizados por profissionais.

iii) Pesquisa de Campo: Entrevistas pessoais junto a dez profissionais da área de eventos, atores representativos em turismo e eventos em Brasília, com vistas a aprofundar informações colhendo evidências objetivas no contexto das estratégias até então adotadas para o gerenciamento de riscos.

iv) Preparação do Manual Prático: Com base nas evidências objetivas, comparação de dados e referências bibliográficas são propostas diretrizes básicas de como administrar um evento com o mínimo de riscos. Estas diretrizes reúnem algumas ferramentas já propostas por outros autores, e incluem de forma inédita a ferramenta SWOT e o PDCA na gestão de riscos em eventos.

\subsection{Amostra e Universo da Pesquisa}

Essa pesquisa adotou a amostragem não-probabilística de conveniência, com uma amostra de dez pessoas em um universo de profissionais cuja atividade está ligada direta ou indiretamente à realização de eventos. 


\subsection{Instrumentos de Coleta de Dados}

A primeira fase do trabalho conglomerou a coleta de dados referentes ao objeto do estudo em questão, abrangendo pesquisas bibliográfica e documental. As informações foram disponibilizadas por meio de livros da área de Turismo e Eventos, de artigos consultados em sites da Internet e de documentos de órgãos governamentais, como o Plano Estratégico de Desenvolvimento Turístico do DF.

Após a análise dos dados coletados, verificou-se a real situação do mercado de trabalho por meio da pesquisa de campo exploratória cujo objetivo era descobrir se os profissionais de eventos utilizavam as técnicas de gerenciamento existentes para aplicá-las em suas rotinas de trabalho, de modo a assegurar o sucesso de suas realizações com o mínimo de riscos.

A pesquisa de campo constituiu a segunda fase do trabalho quando os dados acerca do tema já tinham sido coletados bibliograficamente e, portanto, acrescentados ao saber. As entrevistas foram agendadas em setembro após a listagem dos profissionais que poderiam incrementar com dados relevantes ao tema do estudo. A definição dos entrevistados foi feita segundo critérios de atividade, ou seja, todos necessariamente deveriam trabalhar com eventos independente de sua tipologia, acessibilidade e representatividade junto ao mercado de trabalho. Para a seleção dos entrevistados buscou-se atingir ao maior espectro possível de gestores de eventos que se relacionam com o turismo, como ícones renomados na área de eventos em Brasília.

Acrescenta-se ainda a observação direta intensiva por meio de questionário tipo formulário (apêndice A), que constitui em um instrumento de coleta de dados com uma série ordenada de perguntas respondidas diretamente ao entrevistador. Buscaram-se tanto dados quantitativos quanto qualitativos.

\subsection{Variáveis da Pesquisa}

As variáveis da pesquisa trabalhadas para se atingir os objetivos foram: tempo de experiência, maior evento realizado em termos de público, pré-requisitos 
para a realização de um evento de sucesso, ferramentas utilizadas, maiores fatores de risco, ferramentas conhecidas, ferramentas úteis na organização de um evento, eventos que não alcançaram o sucesso esperado, motivo de insucesso do evento, feedback com cliente e equipe, seleção da equipe de trabalho, freqüência de treinamentos e de improvisação, ferramentas utilizadas para minimizar riscos em eventos e classificação dos eventos em Brasília. A tabulação trabalhou com dois tipos de dados, questões fechadas e abertas. As primeiras foram tabuladas por meio das freqüências absolutas e relativas. As últimas, mediante processo de categorização.

\subsection{Sujeitos da Pesquisa}

Foram entrevistados três profissionais do setor privado, pertencentes à área de eventos; três profissionais encarregados da área de eventos do setor hoteleiro; quatro profissionais encarregados por eventos em órgãos públicos e embaixadas. 


\section{APRESENTAÇÃO E ANÁLISE DOS DADOS DA PESQUISA}

\subsection{Brasília e o Perfil do Turista}

Brasília, criada pelo arquiteto Lúcio Costa e inaugurada em 21 de abril de 1960, é um dos poucos projetos e sonhos urbanos modernistas que se tornaram realidade. Tem o formato de um avião, em que o corpo e as grandes asas abertas formam dois longos eixos perpendiculares. Possui uma área de 5.789,16 Km², com uma população de 2,2 milhões de habitantes e com um PIB nacional de 2,6\%.

A cidade concentra a administração federal e o poder político do Brasil. Os principais órgãos dos poderes Executivo, Legislativo e Judiciário ocupam edifícios desenhados por arquitetos de renome internacional, dentre os quais se destaca Oscar Niemeyer.

Brasília é uma grande exposição de arquitetura arrojada, o que the valeu o título de Patrimônio Cultural da Humanidade conferido pela Unesco. Foi calcada na originalidade do plano urbanístico, estruturado em quatro escalas: monumental, gregária, residencial e bucólica.

A Escala Monumental é representada pelo Eixo Monumental, onde estão dispostos os símbolos do poder político do país. A Escala Gregaria corresponde a todos os setores de convergência da população (comerciais, bancário e hospitalar) e tem como marco a plataforma da Rodoviária do Plano Piloto, símbolo da união com as outras cidades do DF. A Escala Residencial é representada pelas superquadras e seus conjuntos de edifícios sobre pilotis, para garantir a livre circulação de pessoas. E, a Escala Bucólica, premia-se com as demais: são os gramados, praças, jardins, áreas de lazer, Parque da Cidade e a orla do Lago Paranoá.

Atualmente, a capital da República recebe rotineiramente políticos, empresariado e formadores de opinião. Seus equipamentos construídos por Oscar Niemeyer são visitados por turistas de todo o mundo, graças a uma arquitetura ousada de traços modernos e ao fato de ser a única cidade brasileira planejada. 
Segundo o Plano Estratégico de Desenvolvimento Turístico do DF (2005), TABELA 2, o perfil do turista em Brasília possui características próprias:

\section{TABELA 2}

Perfil do Turista do DF

\begin{tabular}{|c|}
\hline Casado e do Sexo Masculino \\
\hline Utiliza o Transporte Aéreo \\
\hline Viaja Sozinho \\
\hline Não Utiliza Agências de Turismo \\
\hline Idade entre 20 e 50 Anos \\
\hline Possui Nível Superior \\
\hline Motivação: Negócios ou Participação em Eventos \\
\hline Permanência Média de 4 Dias, com Taxas Elevadas entre Terças e Quintas-Feiras \\
\hline
\end{tabular}

Fonte: SETUR. Plano Estratégico de Desenvolvimento Turístico do DF, 2005, p. 21.

Segundo dados da SETUR (2002), o principal motivo da vinda de turistas à Brasília, como mostra a FIGURA 4, é por negócios, com 62\% de representatividade. Outras modalidades se responsabilizam pela diferença, como: o turismo de convenções, 14\%; o turismo de lazer, 4\% e 20\% em outros motivos.

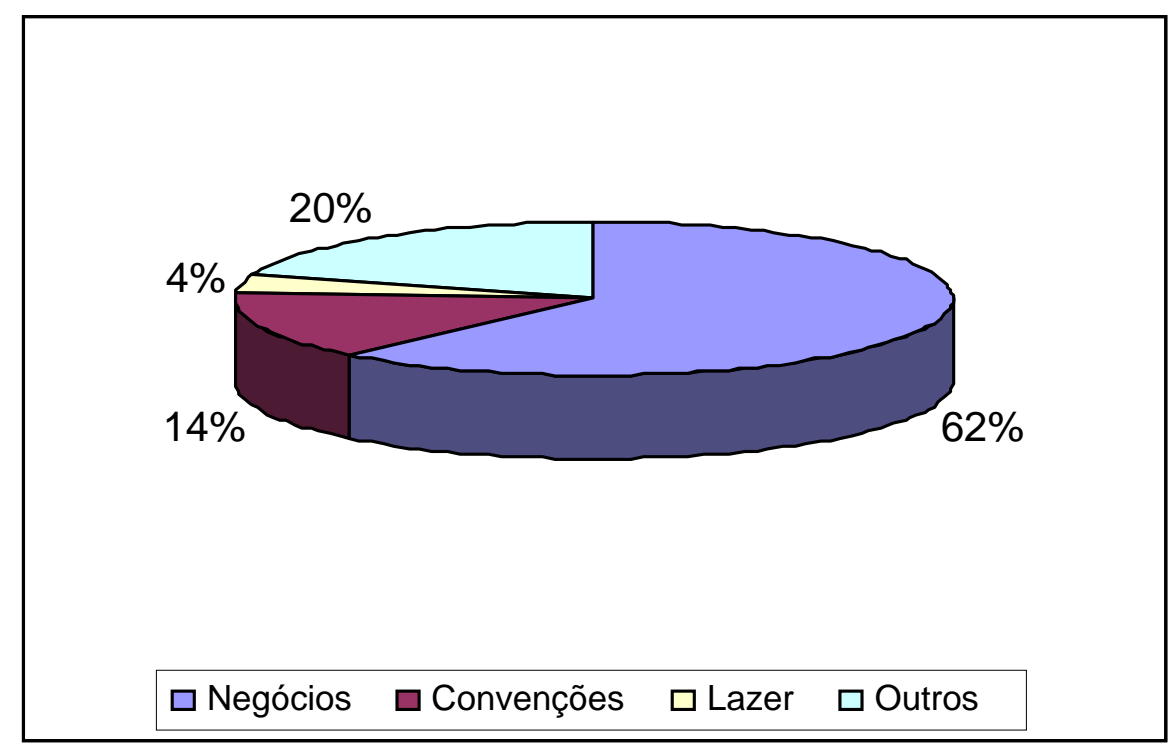

Figura 4: Motivo da vinda de turistas à Brasília

Fonte: SETUR, 2002. 


\subsection{Turismo de Eventos na Capital do País}

O turismo de eventos em Brasília e no DF, segundo informa o Plano Estratégico de Desenvolvimento Turístico (2005), está definido como o segmento que dará suporte ao desenvolvimento de outras tipologias de turismo: místicos /míticos, ecológicos /rurais, cívicos e culturais /arquitetônicos. Isso devido à existência de uma demanda real e potencial para esse segmento assim como infraestrutura disponível para tal fim. Pode-se, assim, verificar a importância do turismo de eventos para a cidade. Por isso, o governo está firmando um novo Plano Estratégico para ampliar o alcance desse segmento objetivando eliminar possíveis entraves à captação de eventos de grande proporção, tendo em vista, a predominância, na cidade, de eventos de pequeno e médio porte, de alcance local e regional.

Brasília tem um grande potencial para sediar eventos, pois se trata de uma cidade cosmopolita, com noventa embaixadas e representações diplomáticas do mundo, representando um universo de culturas típicas. Segundo dados da SETUR (2001) é a segunda maior cidade das Américas em número de usuários de Internet, atrás apenas de Miami, o que representa sua conectividade com o mundo. Sua vocação para eventos conta, recentemente, com o Centro de Convenções revitalizado, com capacidade para 9.000 pessoas, além de várias outras opções que a cidade dispõe como auditórios, salas de conferências e áreas de exposições. A capital possui também um dos maiores pavilhões de feiras e exposições do País, o Expocenter com $58.000 \mathrm{~m}^{2}$. O aeroporto é o terceiro maior do país e em 1996, recebeu o certificado internacional de qualidade ISO 9001. É uma cidade que apresenta ótima localização, ocupa o centro geográfico do Brasil e da América do Sul e a partir de Brasília, o visitante tem acesso fácil e eqüidistante a todas as capitais e principais cidades brasileiras: é a porta de entrada para o Pantanal e a Amazônia, em um momento em que o Meio Ambiente encontra-se em voga, além de receber atualmente 162 vôos diários procedentes das principais cidades brasileiras.

Com relação à infra-estrutura hoteleira, as grandes bandeiras internacionais estão presentes na cidade com um total de 28 mil leitos. A cidade apresenta vantagens aos organizadores e participantes de eventos em virtude de ser 
totalmente planejada: possui pistas largas e retilíneas, concentração estratégica da rede hoteleira, localizada a apenas 15 minutos do aeroporto, 5 minutos da Esplanada dos Ministérios e a 10 minutos do setor de Embaixadas. Conforme dados da SETUR (2005), em relação à segurança, Brasília foi planejada para ser a capital federal, sede dos três poderes da República, possuindo requisitos de segurança que atendam a este fim. É uma vitrine ao país, ou seja, toda realização em Brasília tem grande repercussão na mídia. Como sede das representações internacionais, a cidade reúne uma mistura de culturas mundiais, com variadas opções de lazer e gastronomia, sendo nesse último quesito o terceiro pólo gastronômico do Brasil. Acrescentando-se a esses fatores, cita-se ainda o clima agradabilíssimo com temperaturas amenas e estações bem definidas, e a representação da capital como a cidade-monumento. (Disponível em: <http://www.setur.df.gov.br>. Acesso em: 11 jul. 2005).

Do exposto acima, pode-se afirmar que o segmento turístico em Brasília com maior possibilidade de ascensão é realmente o de eventos, em virtude da infraestrutura e equipamentos oferecidos pela cidade. A seguir, são apresentados dados situacionais dos mercados externo, interno e regional do DF, comprovando a importância do segmento de eventos para a cidade. Na FIGURA 5, observa-se o comportamento do Mercado Externo em relação à Brasília, cujo foco ainda está no segmento arquitetônico-cultural, sendo esse o principal motivo da vinda de estrangeiros ao DF. Todavia, revelou-se um crescente potencial em relação aos segmentos eventos e mítico, onde se prevê representativo crescimento graças a recentes equipamentos voltados para eventos. 


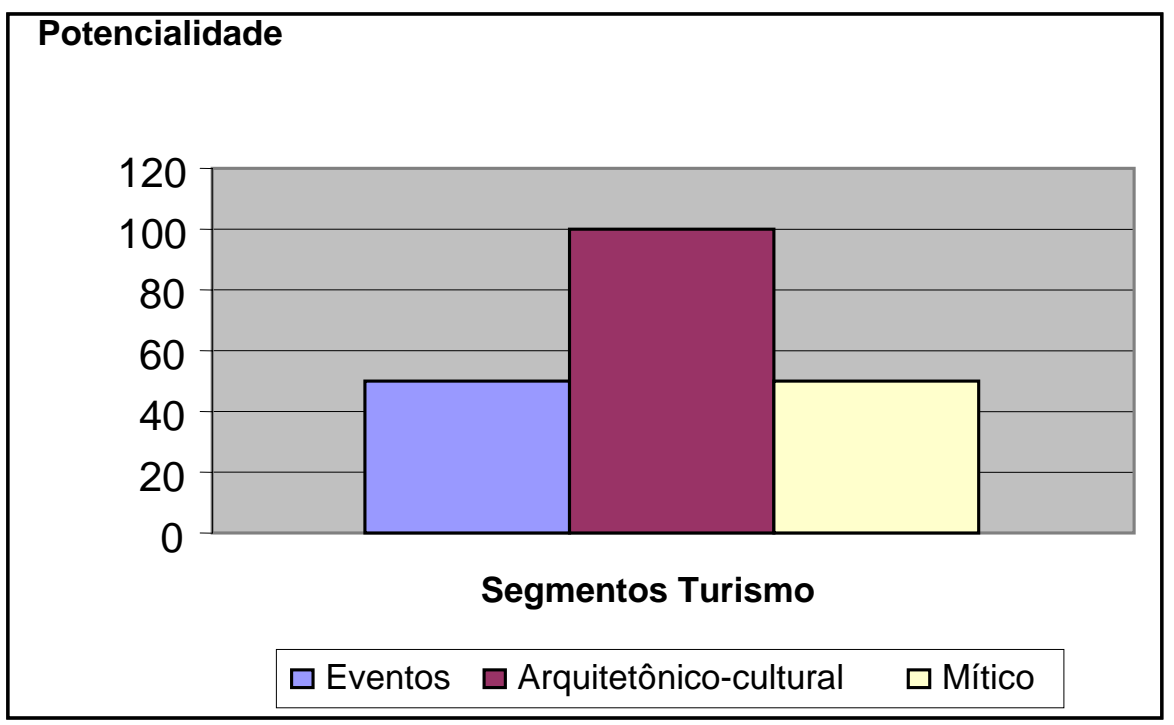

Figura 5: Mercado externo do DF e suas potencialidades

Fonte: SETUR. Plano Estratégico de Desenvolvimento Turístico do DF, 2005, p. 30.

A FIGURA 6 representa o mercado interno do DF, cujo foco aponta para o segmento de eventos, fato confirmado pela própria característica da cidade. A região também é potencialmente vista para a prática dos turismos cívico-arquitetônico e místico-mítico, segmentos também favorecidos pela arquitetura e fusão de culturas.

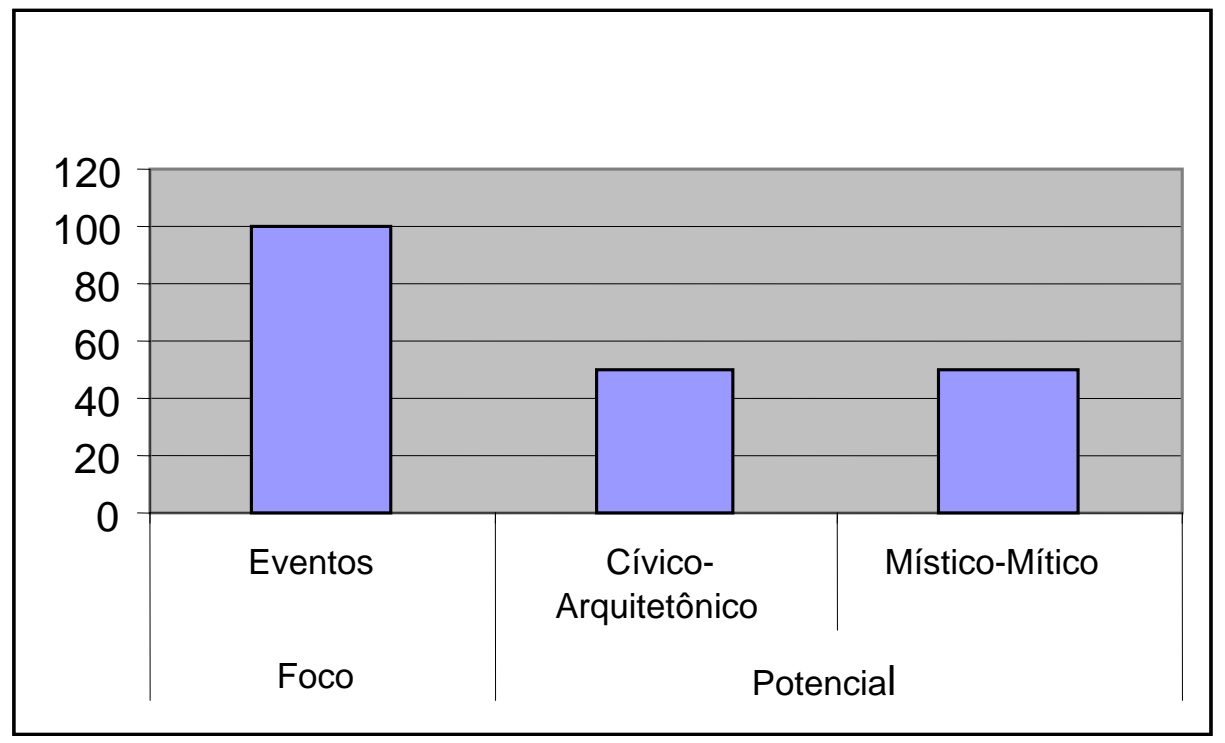

Figura 6: Mercado Interno do DF e suas potencialidades

Fonte: SETUR. Plano Estratégico de Desenvolvimento Turístico do DF, 2005, p. 30. 
Por sua vez, a FIGURA 7, representa a força do turismo rural-ecológico para o mercado regional com potencialidades em todos os outros segmentos presentes no DF, ou seja, o turismo cívico-arquitetônico, místico e eventos.

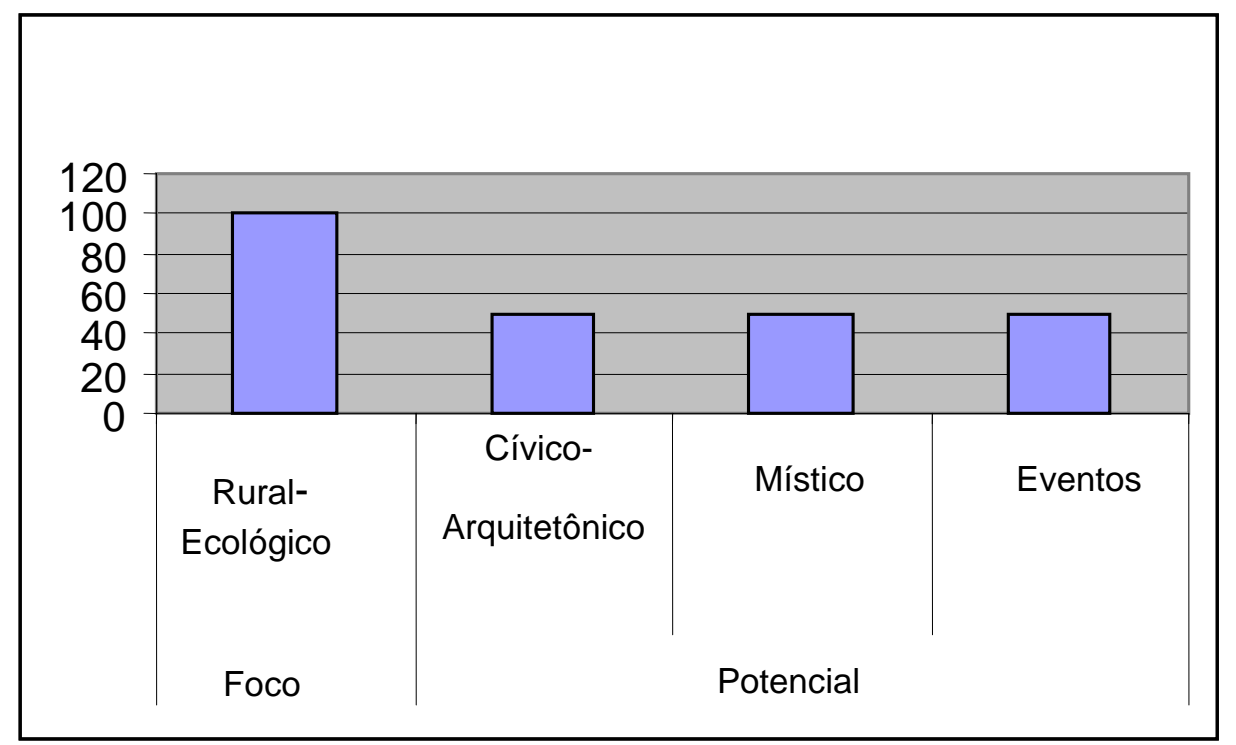

Figura 7: Mercado regional do DF e suas potencialidades

Fonte: SETUR. Plano Estratégico de Desenvolvimento Turístico do DF, 2005, p. 31.

Percebendo o crescimento do turismo de eventos, o governo está desenvolvendo em parceria com uma empresa de Consultoria, o Plano Estratégico de Desenvolvimento Turístico do Distrito Federal (2005). Esse plano abrange vários produtos, os quais possuem, por sua vez, subprodutos, programas e ações. Dentre esses, tem-se o Produto 4, cujo objetivo é apresentar uma estratégia para a estruturação e potencialização da atividade turística do DF, em conformidade com metas e objetivos traçados pelo Governo do Distrito Federal. É importante ressaltar a realização de workshops participativos promovidos em conjunto com a SETUR com o objetivo de validar o diagnóstico da atividade turística na primeira instância, para destacar os pontos fortes e fracos identificados pela consultoria e em segundo, a discussão das principais diretrizes a serem estabelecidas para o desenvolvimento da atividade turística. Foi realizado um seminário com a participação de todo o trade Turístico, congregando o Brasília e Região Convention \&Visitors Bureau, a Associação Brasileira da Indústria Hoteleira, a Associação Brasileira de Restaurantes e Empresas de Entretenimento, o SEBRAE /DF, os Sindicatos e Organizações Não-Governamentais para avaliação dos trabalhos realizados, 
discussão e validação do diagnóstico e da estratégia do plano. Estas ações indicam o interesse na legitimidade e na seriedade do plano estratégico, o que inclui o importante envolvimento dos vários segmentos do ramo turístico por meio dos seus representantes.

A iniciativa privada e o poder público estão investindo recursos em empreendimentos, conforme TABELA 3, com o objetivo de assegurar a ampliação da infra-estrutura de equipamentos, a intensificação da divulgação das potencialidades, a captação e geração de grandes eventos nacionais e internacionais. Como por exemplo, a construção do Centro Cultural da República CCR em que o lado sul é de responsabilidade do poder público e o norte, da iniciativa privada. Criação de um portfólio de qualidade de Brasília pelo Brasília Convention \& Visitors Bureau cujo foco principal é o mercado internacional. A realização do Salão do Turismo, grande evento ocorrido em São Paulo em 2005, reunindo todas as regiões brasileiras, dezessete mil gestores em turismo e cerca de nove mil expositores, onde se foi possível a apresentação de rotas turísticas por cada região brasileira.

TABELA 3

Investimentos em Infra-Estrutura de Eventos

\begin{tabular}{|l|l|}
\hline \multicolumn{1}{|c|}{ PÚBLICO } & \multicolumn{1}{c|}{ PRIVADO } \\
\hline Conjunto Cultural da República & Conjunto Cultural da República \\
\hline Centro de Convenções (GDF) & Inauguração de Hotéis \\
\hline $\begin{array}{l}\text { Implantação do Sambódromo de Ceilândia } \\
\text { (GDF) }\end{array}$ & $\begin{array}{l}\text { Complementação das Obras - Blue Tree Park } \\
\text { Hotel }\end{array}$ \\
\hline & Americel Hall (Academia de Tênis) \\
\hline Fonte: Comparativo de investimentos no setor público e privado (Disponível
\end{tabular}
em:<http://www.sc.df.gov.br>. Acesso em: 25 jul. 2005). 


\subsection{Identificação da Demanda}

Conforme dados resultantes do Plano Estratégico de Desenvolvimento Turístico do Distrito Federal - DF (2005), com o objetivo de se entender melhor a categoria dos visitantes que vêm à Brasília, fez-se uma pesquisa, TABELA 4, no sentido de identificar as demandas existentes, suas características, segmentos dos quais fazem parte e as ações que competem a cada uma delas. Nesse contexto, a região possui, dentre os tipos de demanda existentes, as seguintes: a demanda plena, a demanda irregular e a demanda latente, como mostra a tabela a seguir.

\section{TABELA 4}

\section{Demandas Existentes no DF}

\begin{tabular}{|c|l|l|}
\hline SITUAÇÃO & \multicolumn{1}{|c|}{ CARACTERÍSTICA } & \multicolumn{1}{|c|}{ SEGMENTOS } \\
\hline $\begin{array}{c}\text { Demanda } \\
\text { Plena }\end{array}$ & Nível satisfatório do volume de negócios & $\begin{array}{l}\text { Turismo Institucional /Corporativo } \\
\text { Turismo Rural-Ecológico }\end{array}$ \\
\hline $\begin{array}{c}\text { Demanda } \\
\text { Irregular }\end{array}$ & $\begin{array}{l}\text { Demanda sazonal, característica do } \\
\text { turismo, causa problemas de de } \\
\text { capacidade ideal ou de saturação. }\end{array}$ & $\begin{array}{l}\text { Turismo Institucional /Corporativo } \\
\text { Turismo Rural-Ecológico } \\
\text { Turismo Místico }\end{array}$ \\
\hline $\begin{array}{c}\text { Demanda } \\
\text { Latente }\end{array}$ & $\begin{array}{l}\text { Consumidores compartilham de forte } \\
\text { necessidade que não é satisfeita pelos } \\
\text { produtos existentes no mercado. }\end{array}$ & $\begin{array}{l}\text { Turismo Arquitetônico /Cultural } \\
\text { Turismo Cívico /Arquitetônico }\end{array}$ \\
\hline
\end{tabular}

Fonte: SETUR. Plano Estratégico de Desenvolvimento Turístico do DF, 2005, p.23.

Conforme mostra a pesquisa, vê-se a predominância do segmento institucional-corporativo nas demandas plenas e irregulares, reafirmando mais uma vez a vocação da capital para o turismo de eventos.

Já na TABELA 5 são apresentadas as mesmas demandas, identificando ações específicas e demonstrando o que se pode fazer para manter ou alterar o comportamento das demandas do DF. 


\section{TABELA 5}

Demandas e respectivas Ações

\begin{tabular}{|c|l|}
\hline DEMANDA & \multicolumn{1}{|c|}{ AÇÃo } \\
\hline Demanda Plena & $\begin{array}{l}\text { Manter o nível da demanda diante das mudanças de preferência dos } \\
\text { consumidores e da concorrência, mensurando o nível de satisfação dos } \\
\text { consumidores. }\end{array}$ \\
\hline Demanda Irregular & $\begin{array}{l}\text { Realizar o marketing de sincronização, encontrando maneiras de alterar o } \\
\text { padrão de demanda por meio de flexibilização de preços, promoção e } \\
\text { outros incentivos. }\end{array}$ \\
\hline Demanda Latente & $\begin{array}{l}\text { Mensurar o tamanho do mercado potencial e desenvolver bens e serviços } \\
\text { eficazes para atender a essa demanda. }\end{array}$ \\
\hline
\end{tabular}

Fonte: SETUR. Plano Estratégico de Desenvolvimento Turístico do DF, 2005, p. 22.

Conforme informações do Plano Estratégico do DF (2005), as demandas plenas, que correspondem ao turismo institucional /corporativo e ao turismo ruralecológico, podem ser consideradas também como demandas irregulares, pelo fato do primeiro segmento se concentrar nos dias de semana e o segundo, nos dias de finais de semana e feriados, proporcionando a sazonalidade em ambos os casos. Já nas demandas latentes estão o turismo arquitetônico /cultural e o turismo cívico larquitetônico. Há também na demanda irregular a presença do turismo místico.

Tomando-se como base as informações descritas nas tabelas apresentadas, das demandas e dos dados do perfil do turista, conclui-se que a demanda de negócios para o DF, particularmente para Brasília, é o turismo institucional /corporativo. Segundo a definição que consta no próprio Plano Estratégico (2005) elaborado pela Secretaria de Turismo em conjunto com a empresa de Consultoria contratada, cita-se:

O segmento de negócios se caracteriza pelo conjunto de atividades de viagem, de hospedagem, de alimentação e de lazer praticado por quem viaja a negócios referentes aos diversos setores da atividade comercial ou industrial ou para conhecer mercados, estabelecer contatos, firmar convênios, treinar novas tecnologias, vender ou comprar bens ou serviços. Dentro do turismo de negócios, o turista institucional /corporativo se caracteriza como aquele que se desloca com o objetivo de fazer exclusivamente gestões institucionais e que, não necessariamente, 
contribui para a economia do destino visitado. Seu deslocamento, portanto, tem como motivação fazer a aproximação ou criar vínculos com instituições privadas e /ou instituições públicas. (Plano Estratégico de Desenvolvimento Turístico do DF, 2005, p. 23).

Pode-se dizer que a oferta turística do DF está formatada para o turista institucional /corporativo, exceto os empreendimentos de turismo no espaço rural. Afirmação essa que pode ser comprovada pelo fato de haver poucas áreas sociais destinadas ao lazer, principalmente nos estabelecimentos de hospedagem cuja área é mínima pela própria característica dos empreendimentos de Brasília, em que se predomina a verticalidade e por isso, sem grandes áreas para montar equipamentos para esse fim. Além disso, vê-se a predominância de espaços para eventos e centros de negócios.

Frente aos fatores favoráveis à realização de eventos na capital e considerando o crescimento da demanda por essa atividade, torna-se indispensável um gerenciamento que minimize os possíveis riscos por meio da apresentação de diretrizes básicas de cada etapa do planejamento do evento.

\subsection{Práticas Gerenciais na Indústria de Eventos de Brasília}

Brasília possui dezesseis empresas de realização de eventos cadastradas na Associação Brasileira de Empresas de Eventos - ABEOC (anexo A). Estas empresas trabalham com o segmento de eventos, o que inclui projetos de pequeno, médio e grande porte. Dentre as mesmas, existem a considerada VIP, por atender clientes importantes e eventos de grande porte, e aquelas que se encarregam de eventos rotineiros. Para verificar o que está sendo praticado na rotina de trabalho dos profissionais da área de eventos na cidade, foram aplicados questionários (apêndice A) junto a dez gestores de renome da área, pertencentes ao ramo da hotelaria e coordenadores de eventos patrocinados por empresas e/ ou órgãos do governo. 
O tempo de trabalho que cada entrevistado tem como organizador de eventos, conforme FIGURA 8, indica o tempo de experiência dos profissionais que atuam no mercado de Brasília.

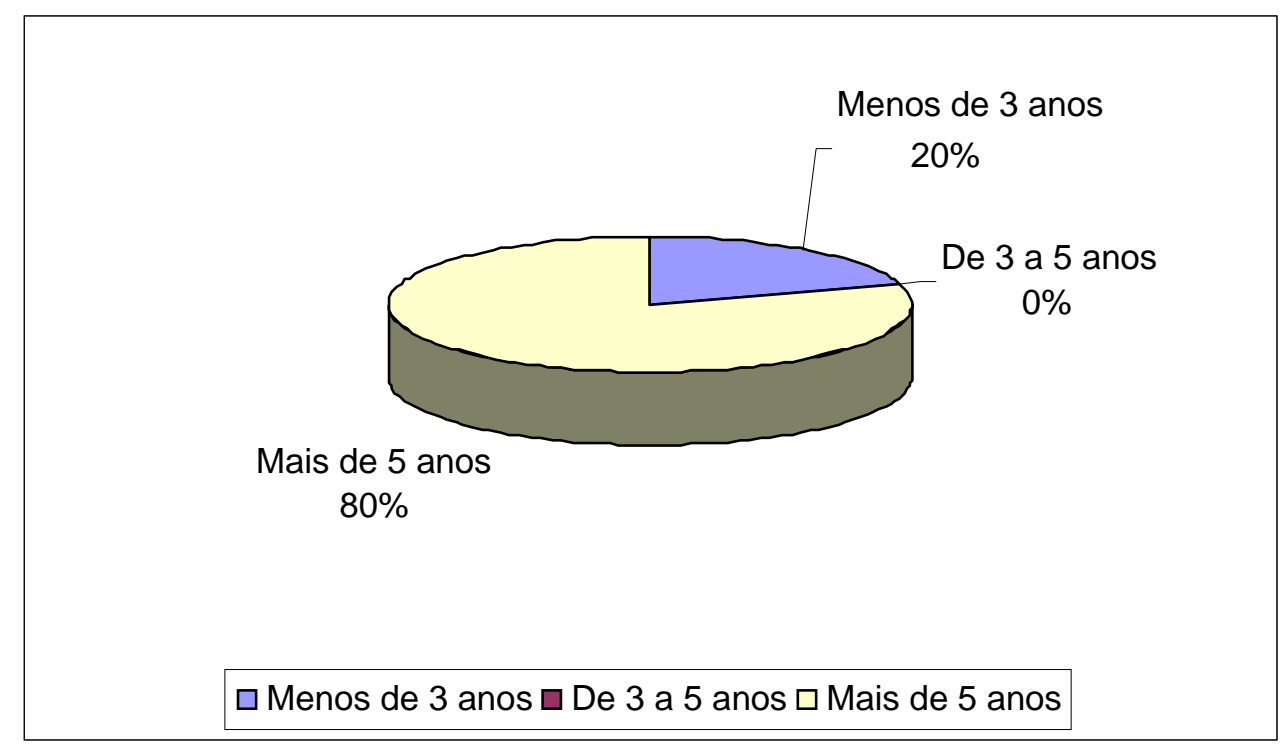

Figura 8: Experiência de trabalho dos profissionais entrevistados

A partir da análise do gráfico acima, a maioria dos entrevistados tem mais de cinco anos de experiência, o que demonstra que possuem um histórico na organização de eventos. Tal conhecimento não foi fruto de formação acadêmica na área específica de eventos, sendo nenhum deles formados na área. Os entrevistados iniciaram sua atuação neste mercado por circunstâncias diversas, mas responderam que procuram manter-se atualizados e demonstraram ser pessoas dinâmicas e com vontade de continuar atuante na área.

Agregando aos anos de experiência, os gestores demonstraram conhecimento e prática na realização de eventos de grande porte, FIGURA 9, em termos de público. O dado demonstra a habilidade desses profissionais em lidar com situações adversas, como a magnitude de público. 


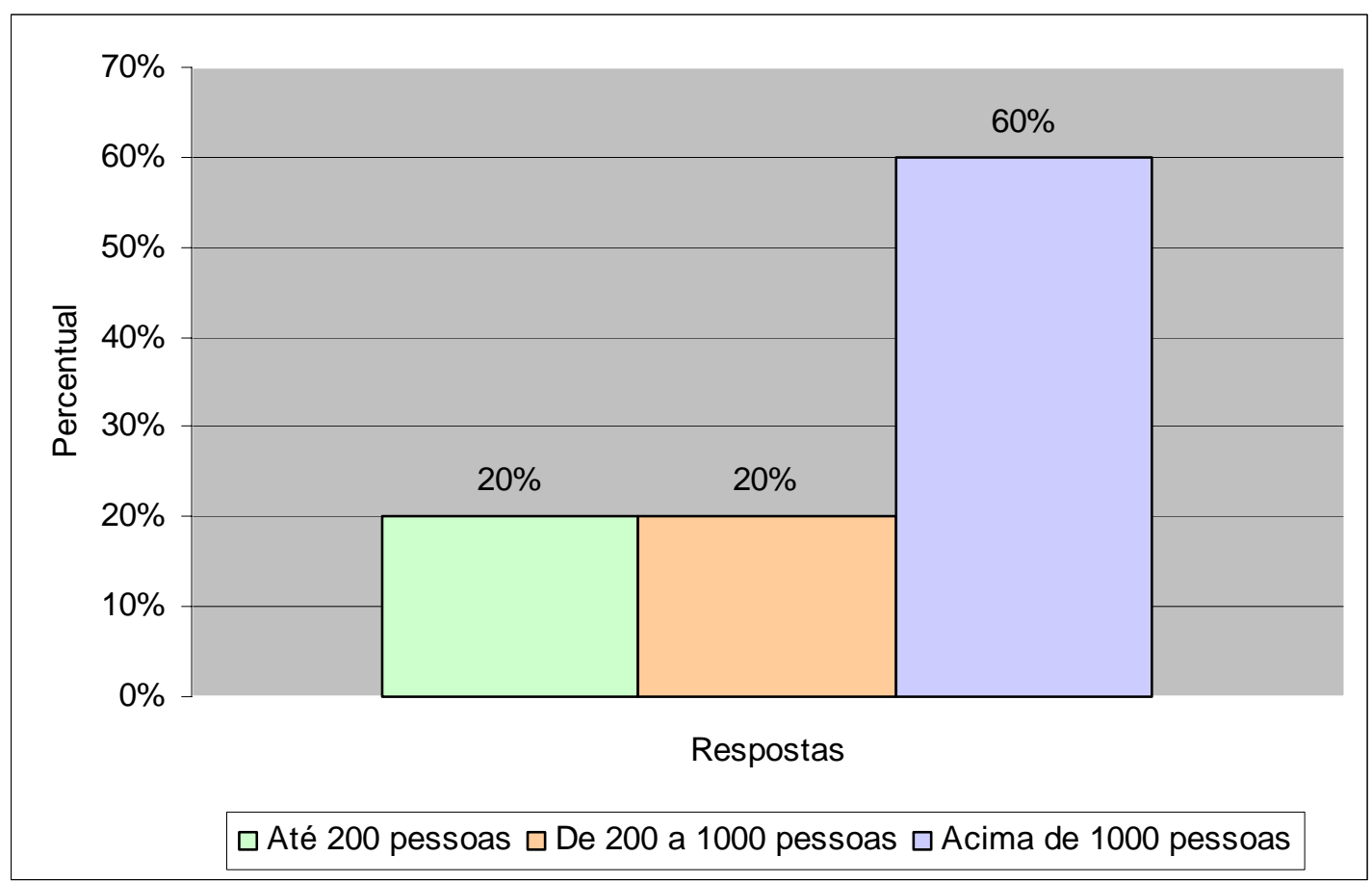

Figura 9: Maior evento realizado

Pelas respostas obtidas, $60 \%$ dos entrevistados já realizaram eventos para público acima de 1000 pessoas e 40\%, ainda não tiveram essa experiência. Trata-se de dado coerente visto que Brasília não oferecia, até início de 2005 , condições e equipamentos suficientes para comportar um grande volume de público. É importante enfatizar que o planejamento de um evento seja para dez como para dez mil pessoas, é o mesmo. A quantidade de pessoas e a experiência com volume de público, entretanto influencia diretamente nos riscos, o que exige maior detalhe no gerenciamento. Um dos entrevistados, por exemplo, afirmou ter vivenciado experiência negativa de evento realizado por ele, em relação à quantidade de público além do planejado. O fato gerou graves transtornos, levando-o a fechar as portas do salão e convocar a polícia e os seguranças. Tratava-se de inauguração de loja famosa nacionalmente, o que gerou uma imagem negativa aos organizadores, à loja e à marca.

Importante fator condicionante do sucesso de um evento é o grau de importância atribuído pelos gestores de eventos às diversas fases de realização do mesmo. O grau de importância do Gerenciamento de risco, conforme demonstra a FIGURA 10, atribuído pelos entrevistados é inexpressivo. 


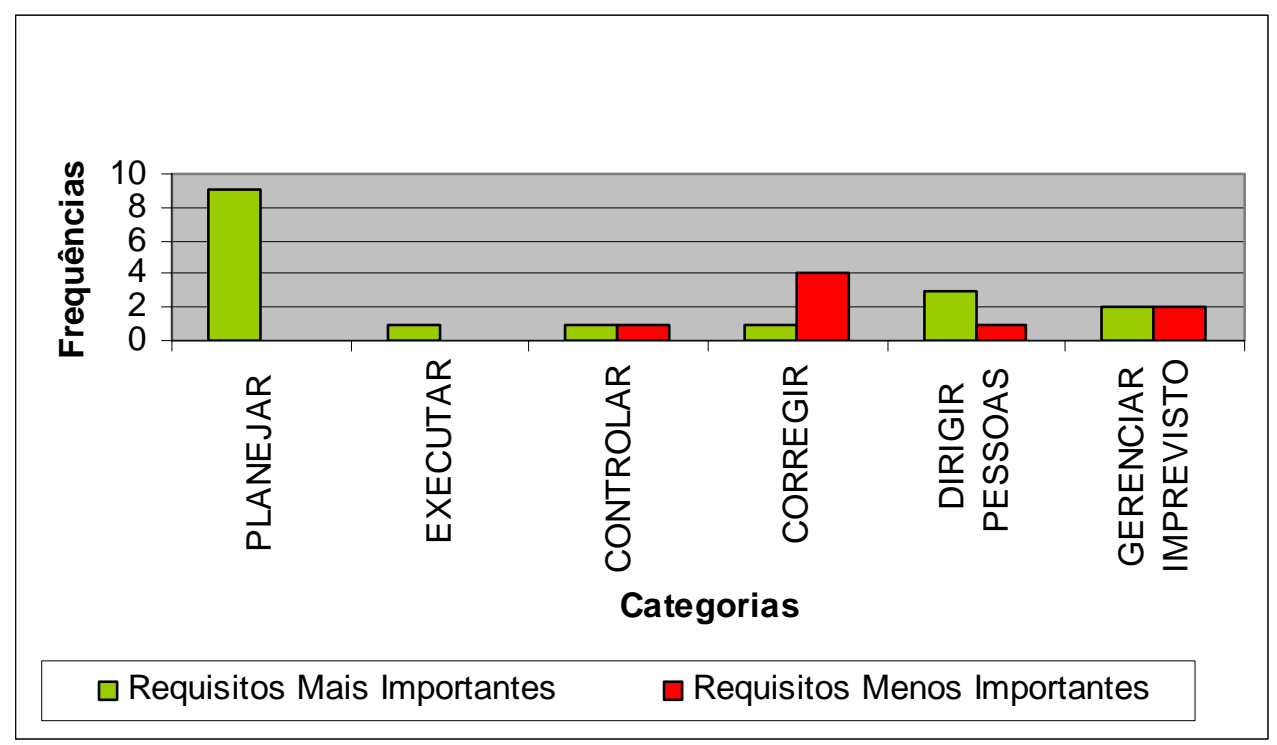

Figura 10: Pré-requisitos para organização de um evento

Ora, se considerarmos que $40 \%$ dos entrevistados não possuem experiência com mega eventos e com certeza, terão mais riscos a gerenciar quando destas realizações, e que apenas $20 \%$ do total dos entrevistados atribuam importância ao gerenciamento de riscos e imprevistos, demonstra-se a urgente importância de inclusão desta fase, uma vez que cresce em quantidade e número o turismo de eventos, demandando experiência de volume de público de seus organizadores.

Pelas respostas obtidas, puderam-se verificar quais procedimentos os profissionais estão utilizando na sua rotina de trabalho. Os requisitos mais importantes foram o Planejamento e a direção de pessoas. Por sua vez, os menos importantes, foram a Correção e o gerenciamento de imprevistos, que obteve o mesmo número de pontuações da outra categoria. Conclui-se que as pessoas não se preocupam com a etapa do Corrigir por pensarem que não acontecerá nada ou resolverão na hora que o imprevisto acontecer, em conseqüência, a freqüência de pontuações para a categoria de Gerenciamento de imprevistos também foi baixa.

A utilização de técnicas aplicadas no planejamento de um evento durante a rotina de trabalho de cada profissional, é garantia de sucesso o insucesso. O Checklist é uma das ferramentas mais simples, porém pouco consistente no que se refere à análise de riscos. Mas, como demonstra a FIGURA 11, é a mais rotineiramente utilizada pelos gestores em Brasília. 


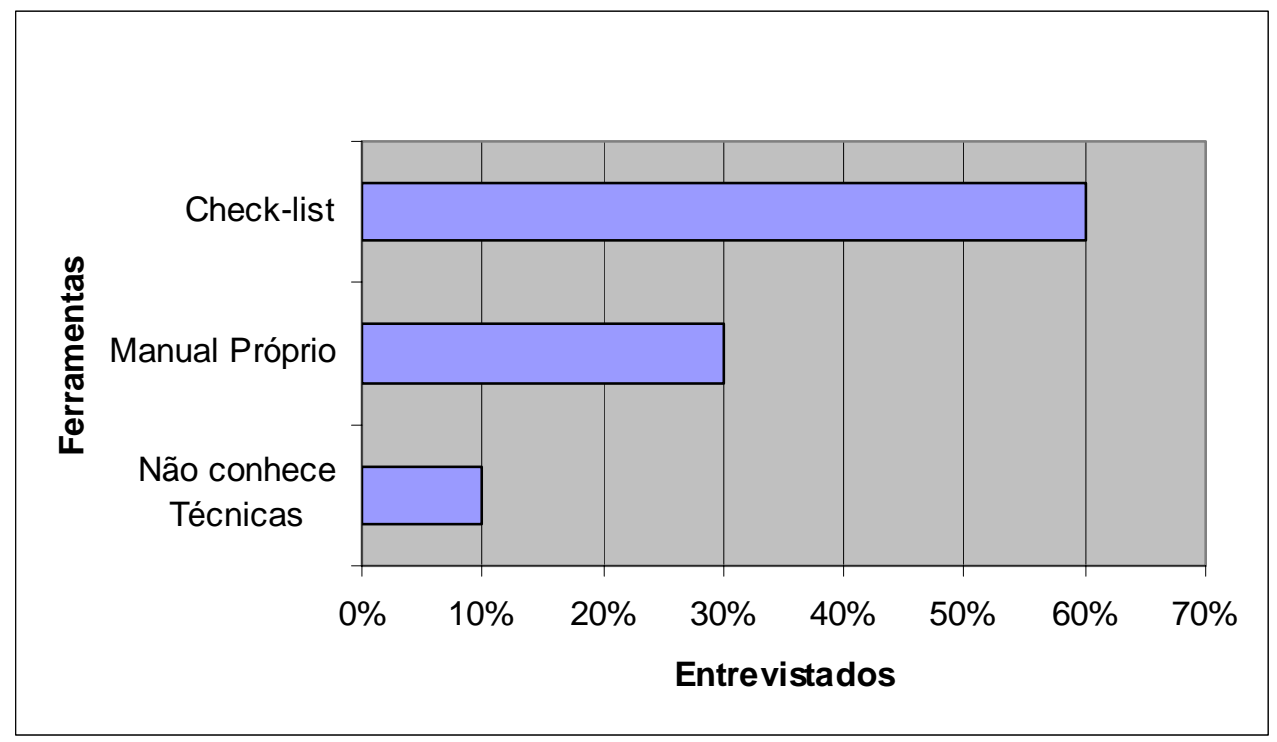

Figura 11: Ferramentas mais utilizadas pelos gestores

Sendo a técnica do Check-list a mais utilizada, seguida de um manual próprio da empresa, pode-se inferir que as pessoas não conhecem as técnicas de gerenciamento existentes até o presente momento. Partindo desse raciocínio, podese afirmar que o gerenciamento pode em muito melhorar por meio da utilização de técnicas básicas que levam em conta todas as fases, da concepção ao pós-evento.

Dentre as técnicas existentes para aplicação no gerenciamento de eventos, poucas delas são conhecidas ou utilizadas pelos gestores. De acordo com as respostas obtidas, confirmou-se que o Check-list, conforme FIGURA 12, era o mais conhecido e praticado. Foi citada também a análise SWOT, conforme a mesma figura, como alternativa para o gerenciamento. 


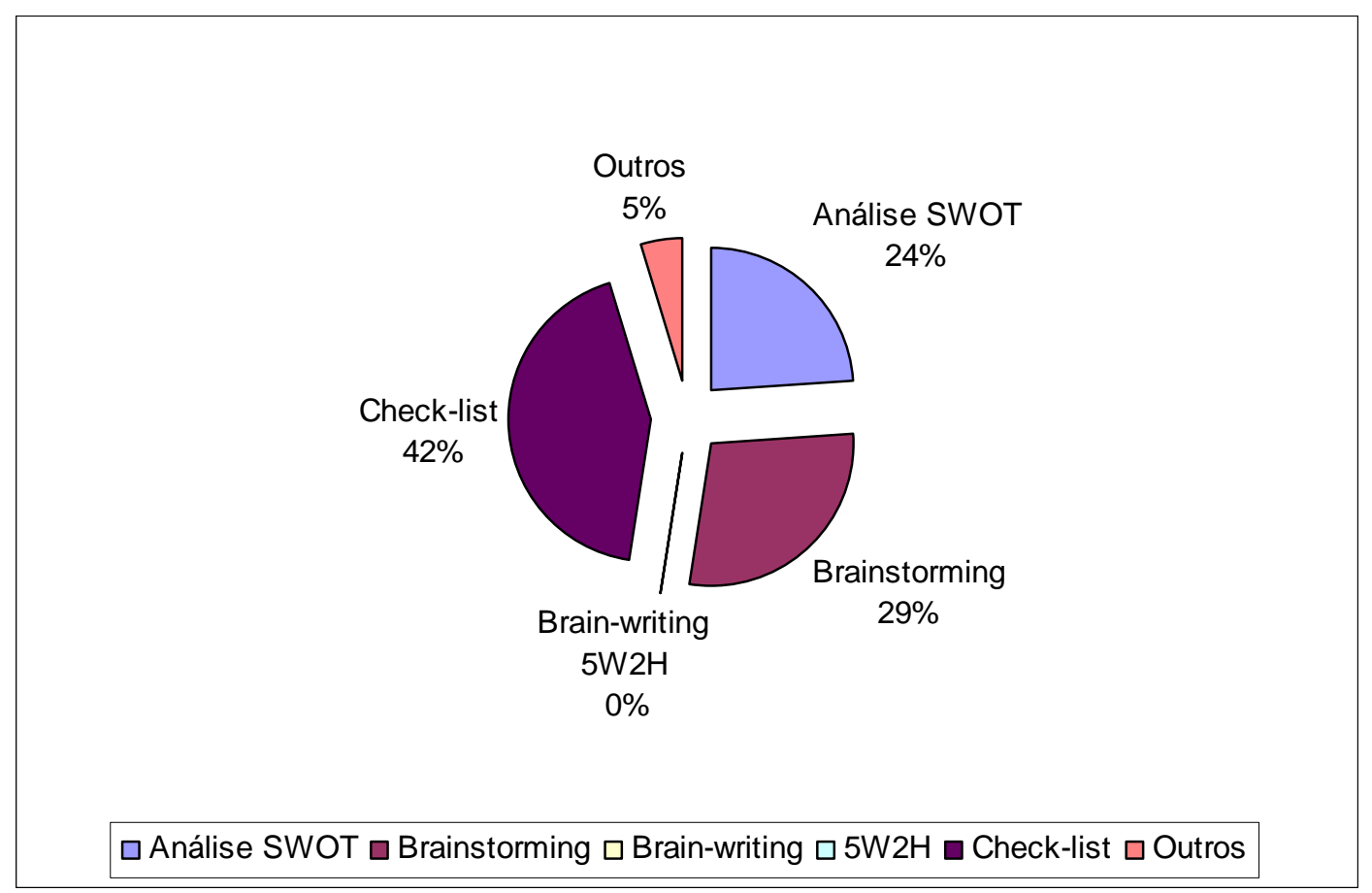

Figura 12: Ferramentas mais conhecidas e utilizadas no gerenciamento

A utilização da análise SWOT em 24\%, entretanto, dá-se de maneira empírica e não sistêmica. Após a apresentação das técnicas mencionadas, os entrevistados perguntaram o que era a análise SWOT e com a explicação afirmaram que conheciam e aplicavam. Porém, somente um deles detalhou, voluntariamente, utilizar essa ferramenta em suas análises.

Quando perguntados o porquê da utilização dessas técnicas no gerenciamento dos eventos, a maioria respondeu referindo-se às técnicas do Checklist como uma lista de atividades a serem cumpridas. No caso dos gestores de eventos no ramo hoteleiro entrevistados, a técnica utilizada era um Manual próprio peculiar de cada estabelecimento. $E$ todos os entrevistados manifestaram interesse em conhecer e aplicar as demais ferramentas mencionadas no questionário.

Vários são os fatores de riscos em eventos, o que indica forte importância o seu gerenciamento. Os entrevistados demonstram saber que os riscos existem, são diversos e muitas vezes específicos a cada natureza de evento. 


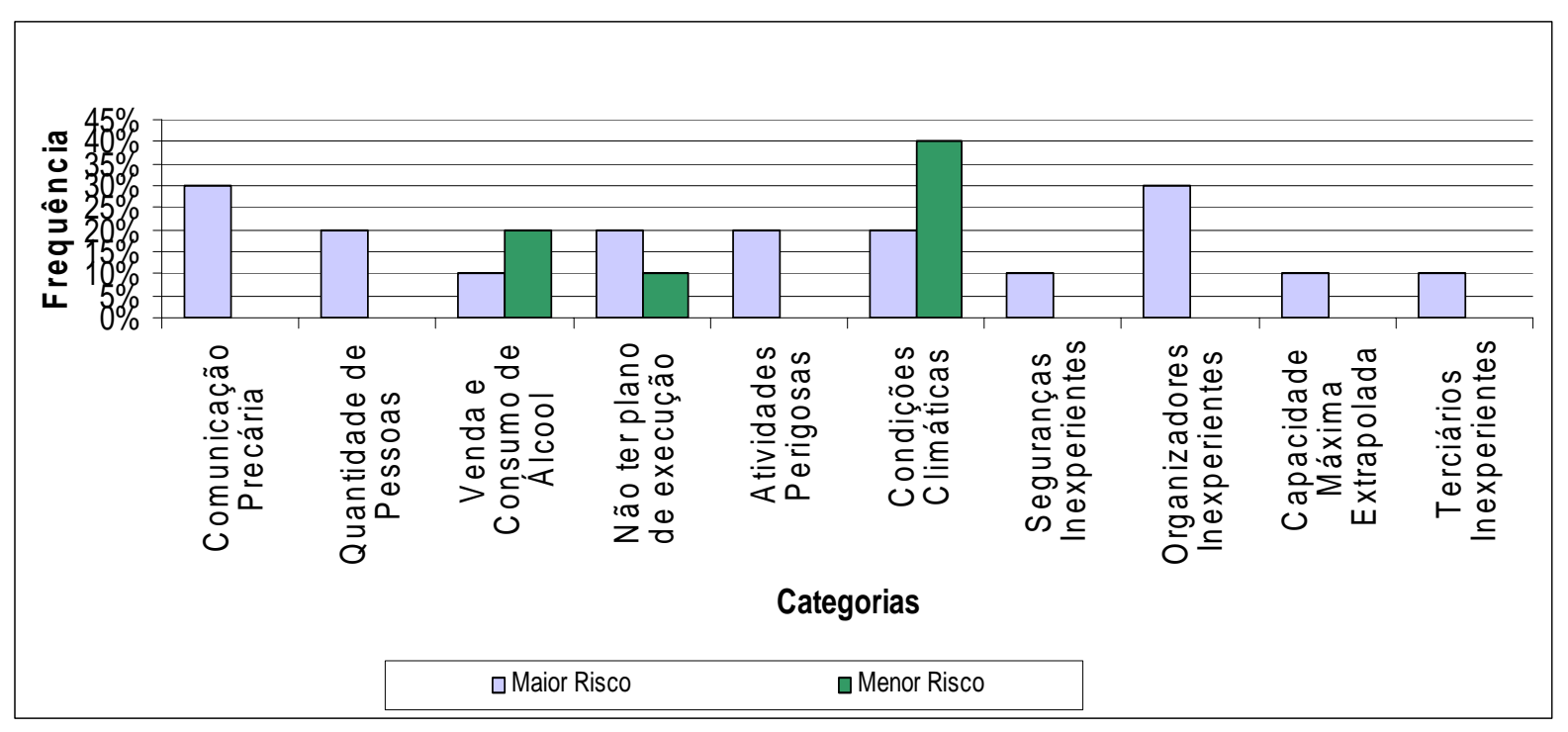

Figura 13: Maiores e menores fatores de risco

A FIGURA 13 registra os maiores e menores fatores de risco apontados pelos entrevistados. Os maiores fatores de risco foram a Comunicação precária e os Organizadores inexperientes e o menor, as Condições climáticas. Alguns gestores mencionaram a Comunicação como um grande risco ao evento, porém indicou soluções para esse problema, como, por exemplo, fazer com que os funcionários envolvidos executassem as tarefas tão logo o coordenador as tivesse explicado como deveriam se feitas. As Condições climáticas representaram o menor fator de risco, pois a maioria dos entrevistados fez seus eventos em locais fechados, por isso livre de influências da natureza.

Os gestores de eventos demonstram não dar muita importância a fatores de risco que podem impactar na qualidade dos eventos, como por exemplo, Terciários inexperientes e a Falta de plano de execução.

Brasília inicia 2005 como a época de realização de maior quantidade de mega eventos, graças ao incentivo do governo em equipamentos e fomentação do mercado.

Por outro lado, apenas 60\% dos gestores em turismo de Brasília possuem experiência com eventos para público acima de mil pessoas. 
Considerando a falta de freqüência de mega eventos, procurou-se identificar, conforme FIGURA 14, se esses menores eventos eram conduzidos com o alcance do sucesso.

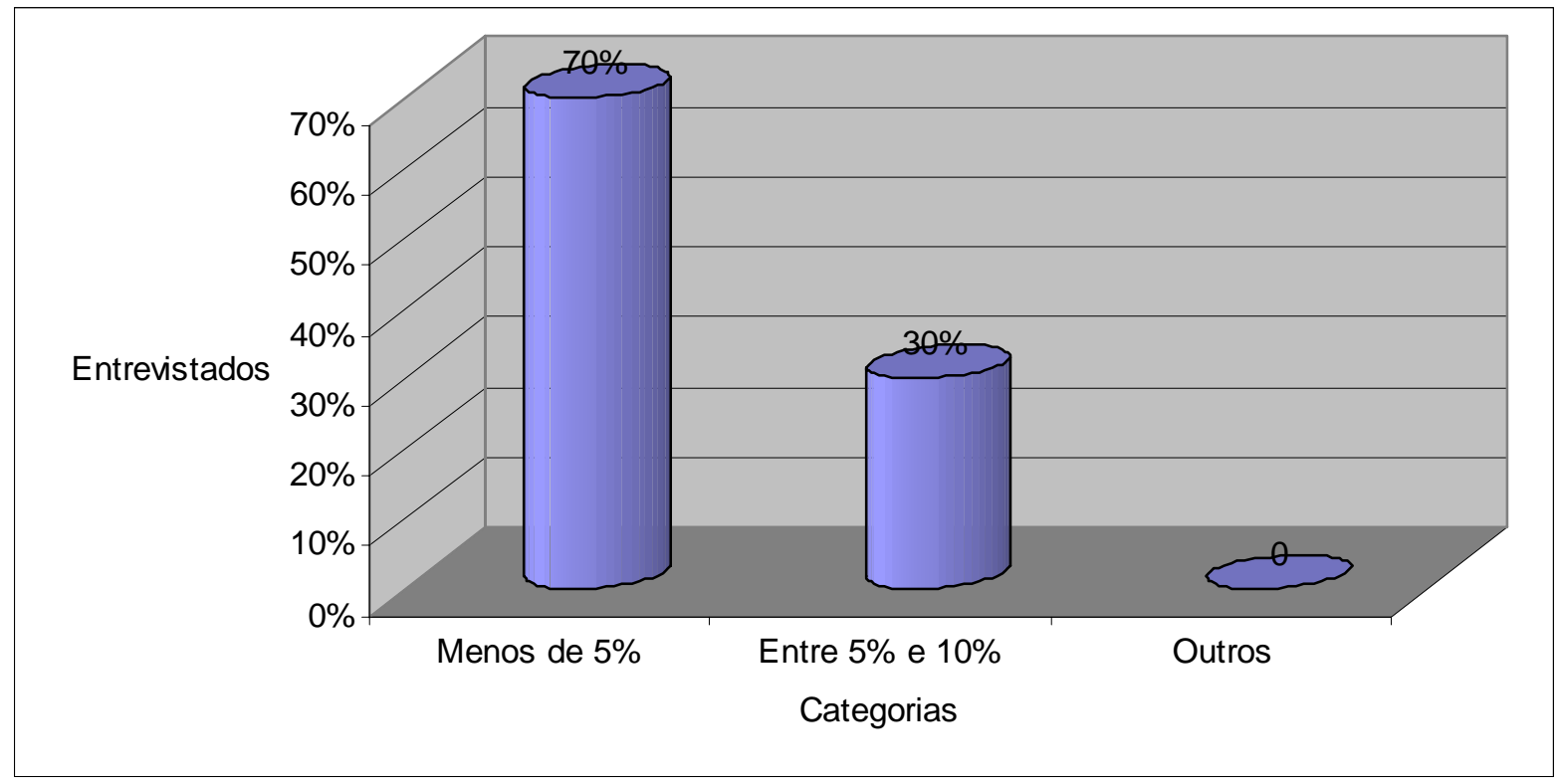

Figura 14: Percentual de eventos realizados que não obtiveram o sucesso esperado

Mesmo sendo eventos para menores volumes de público, o sucesso total do evento não foi alcançado pelos entrevistados. E o grande percentual de $30 \%$ de insucesso foi vivenciado em mais de $5 \%$ dos eventos realizados por cada um deles. Os entrevistados citaram trabalhar os riscos com ações corretivas e não, preventivas, como deveriam.

Identificar o motivo do insucesso dos eventos leva à melhoria contínua no gerenciamento de riscos. Falta de planejamento, recursos e dificuldades de mão-deobra são fatores que comprometem a realização do evento, conforme FIGURA 15. 


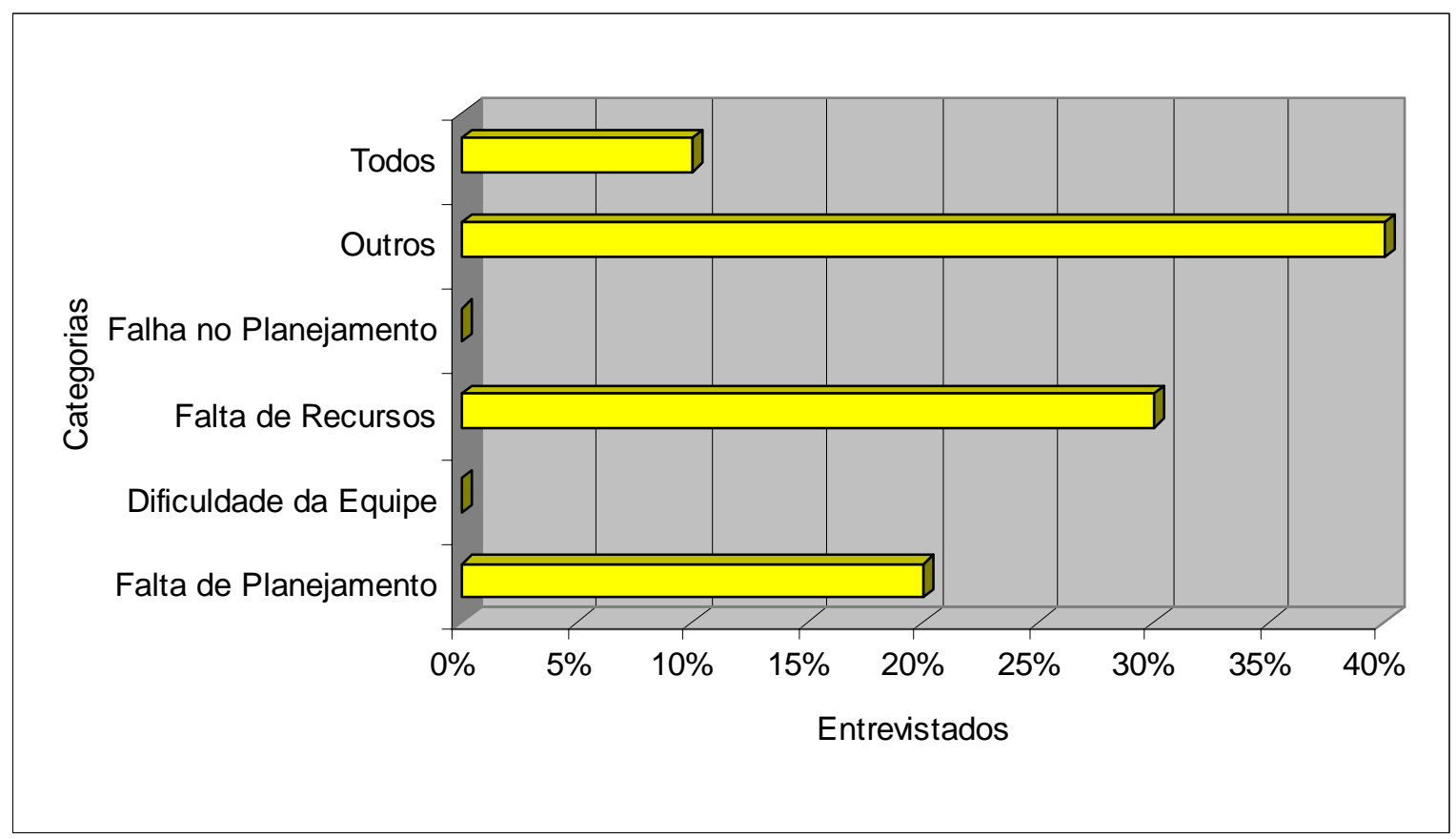

Figura 15: Motivo de insucesso dos eventos

Nenhum entrevistado identificou a análise dos Pontos fortes, Pontos fracos, Ameaças e Oportunidades como um importante método na gestão de riscos em eventos. As condições climáticas foram apontadas como sendo fator de insucesso dos eventos pelo motivo de não se ter um controle muito grande em se prever as variações de clima. Hoje em dia, com a tecnologia e a era das informações, esse fator pode ser previsto, por exemplo, por meio da consulta a um site de meteorologia, como sugeriu um dos entrevistados. O outro motivo que entrou nessa categoria foi problema com a comunicação.

Com relação a registro de feedback com o cliente, $30 \%$ dos entrevistados que trabalham em empresas de organização de eventos afirmam, conforme FIGURA 16, não manter o feedback entre empresa e cliente após a realização do evento. São profissionais que realizam eventos direcionados de acordo com a sua área principal de atuação, como por exemplo, os que servem em órgãos públicos. Essas pessoas geralmente realizam cerimônias oficiais com representantes diplomáticos e do governo. 


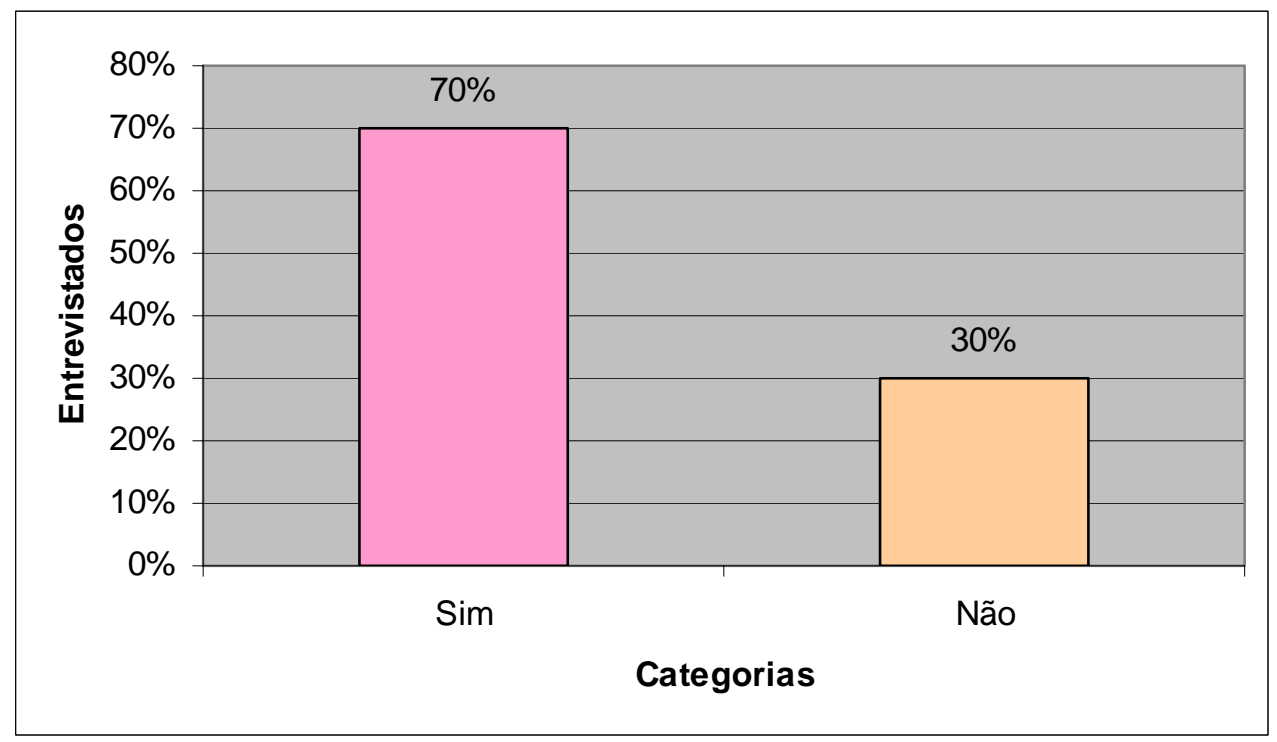

Figura 16: Registro de feedback com o cliente

Realizar como procedimento reunião de feedback com a equipe de trabalho é fator importante para a melhoria contínua. A FIGURA 17 demonstra que é prática dos gestores em Brasília em fazer fazem um levantamento de resultados com a equipe de trabalho.

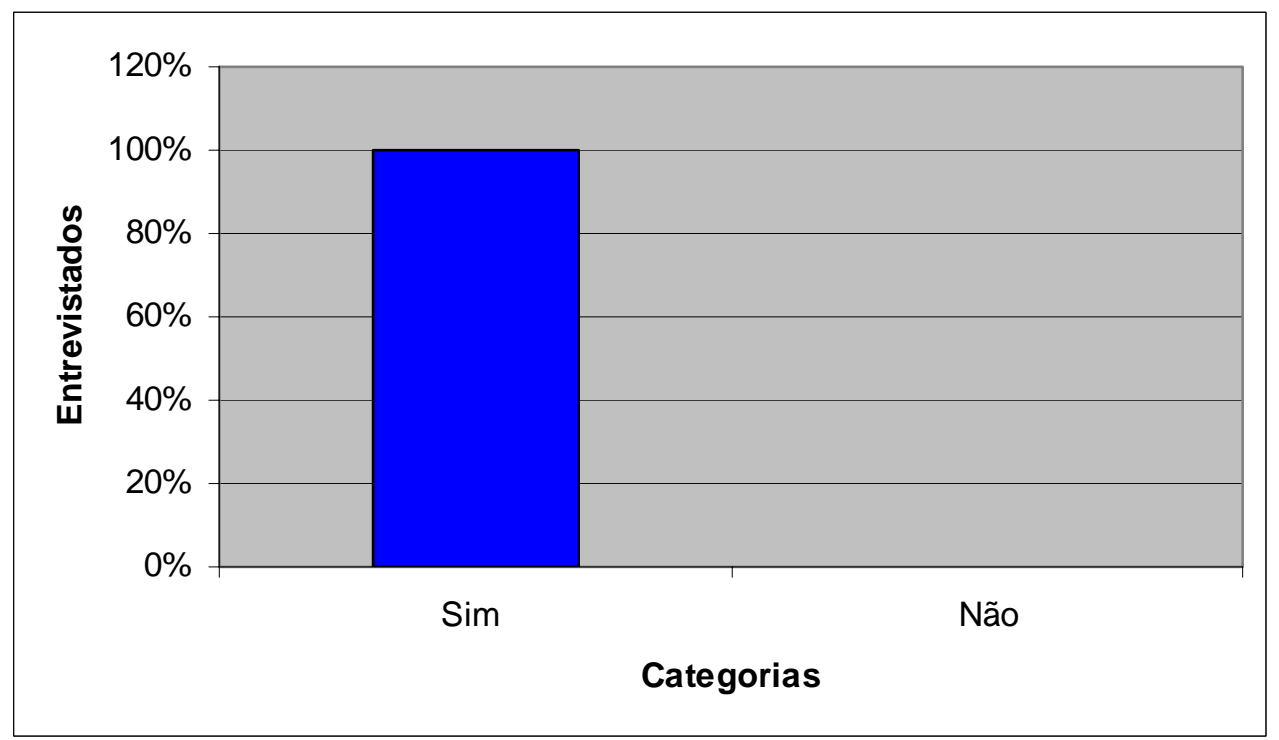

Figura 17: Registro de feedback com a equipe de trabalho

O feedback com a equipe é considerado pelos gestores ser de extrema importância objetivando levantar os resultados do evento com o propósito de identificar oportunidades de melhoria, evidenciar críticas e sugestões, identificar a 
qualidade de relacionamento entre os membros da equipe, confrontar os pontos positivos e os negativos, as oportunidades e as ameaças.

A ocorrência de organização de eventos em uma empresa da área é sazonal, o que prejudica a contratação de equipe fixa de trabalho. Uma das principais dificuldades apontadas pelos gestores em Brasília refere-se à contratação de boa mão-de-obra. Se por um lado nos grandes centros como, por exemplo, em São Paulo, seleciona-se facilmente 400 pessoas em uma amostra de 700 entrevistados, o mesmo não ocorre ainda em Brasília devido a grande dificuldade em se encontrar profissionais qualificados para a área. A principal forma de realizar estas contratações é por meio de prestadoras de serviços. Outra alternativa encontrada pelos gestores, conforme FIGURA 18, é a utilização de pessoas do próprio trabalho, como exemplo as Embaixadas, que ao realizar um evento oficial não contratam nenhuma empresa.

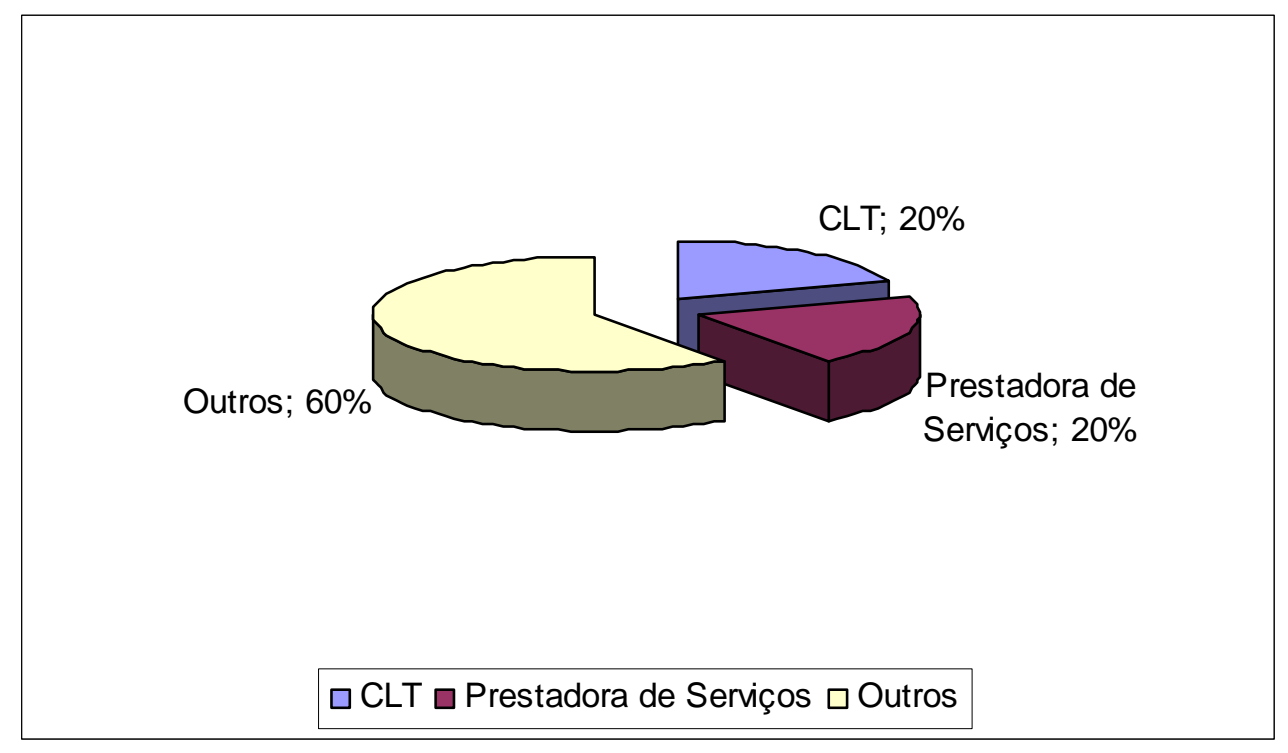

Figura 18: Tipo de seleção da equipe de trabalho

Diante da importância de se ter na empresa profissionais qualificados, diverge o dado quanto à freqüência de treinamentos realizados com a equipe. Menos de $1 \%$ dos entrevistados, conforme FIGURA 19, fazem treinamentos com a equipe de trabalho. 


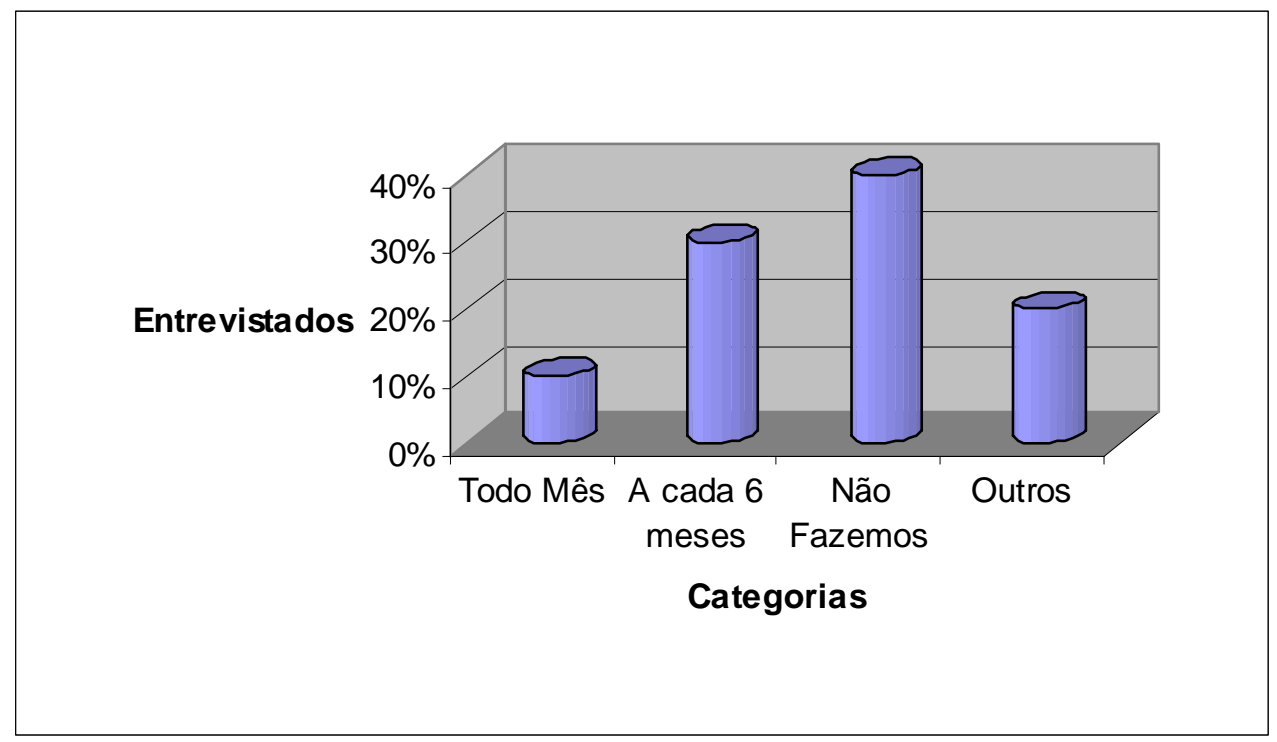

Figura 19: Freqüência de Treinamentos

A improvisação também faz parte da rotina dos gestores de eventos na capital. Apesar do planejamento realizado, mais da metade dos profissionais desta área, conforme FIGURA 20, improvisam sempre em seus eventos.

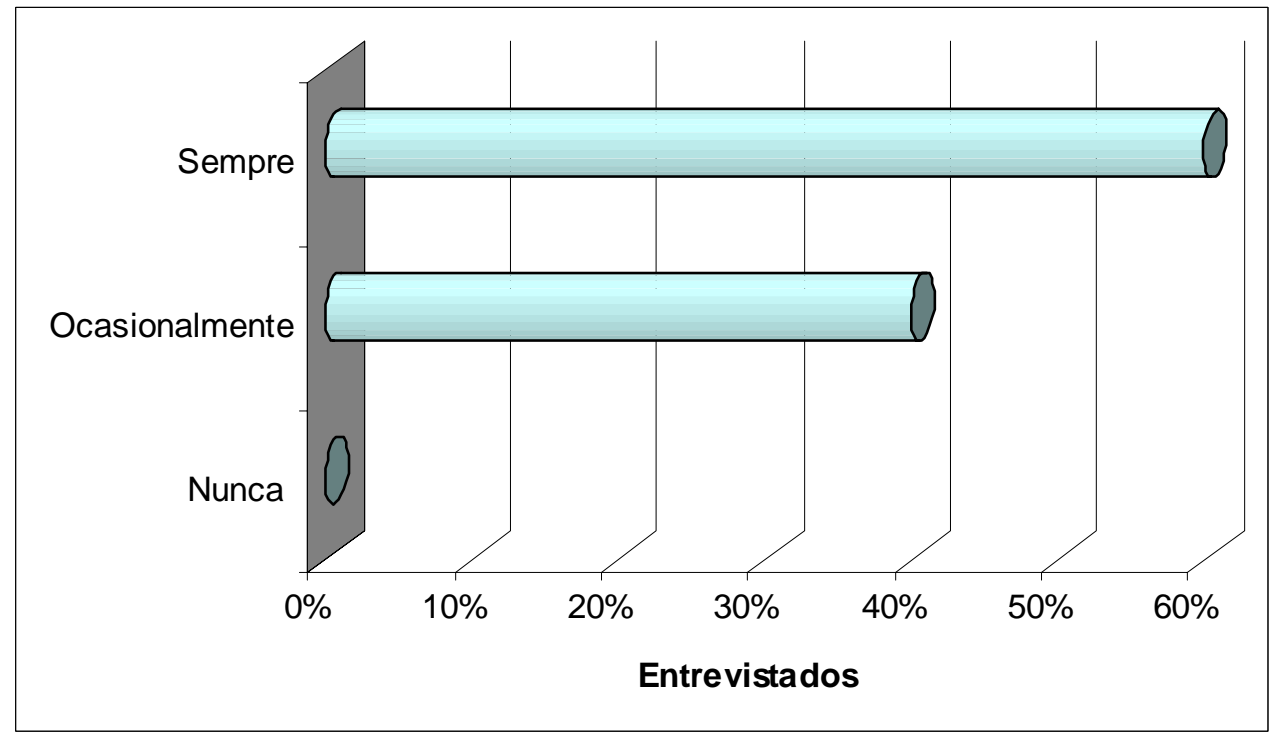

Figura 20: Freqüência de Improvisação

A falta da análise SWOT antes do evento, verificando os Pontos fortes, os Pontos fracos, as Oportunidades e as Ameaças interfere na intensidade de ocorrências que levam à improvisação. Considerando-se que a maioria das respostas indicaram a freqüência de improvisação, vê-se a necessidade de elaborar estudos que apresentem meios pelos quais os improvisos possam ser minimizados. 
A FIGURA 21 demonstra as práticas mais e menos utilizadas pelos gestores de eventos. A partir das respostas, constatou-se que o Check-list e o Planejamento de cada evento fazem parte da rotina dos coordenadores de evento, ao contrário da Pesquisa e da utilização de um Manual próprio. A utilização do Check-list, como prática mais utilizada e como ferramenta mais conhecida e aplicada, ocorre devido à facilidade dessa técnica, tanto em termos de aplicação como em termos de controle do que se está sendo feito. De toda forma, nenhuma das práticas obtiveram percentuais representativos.

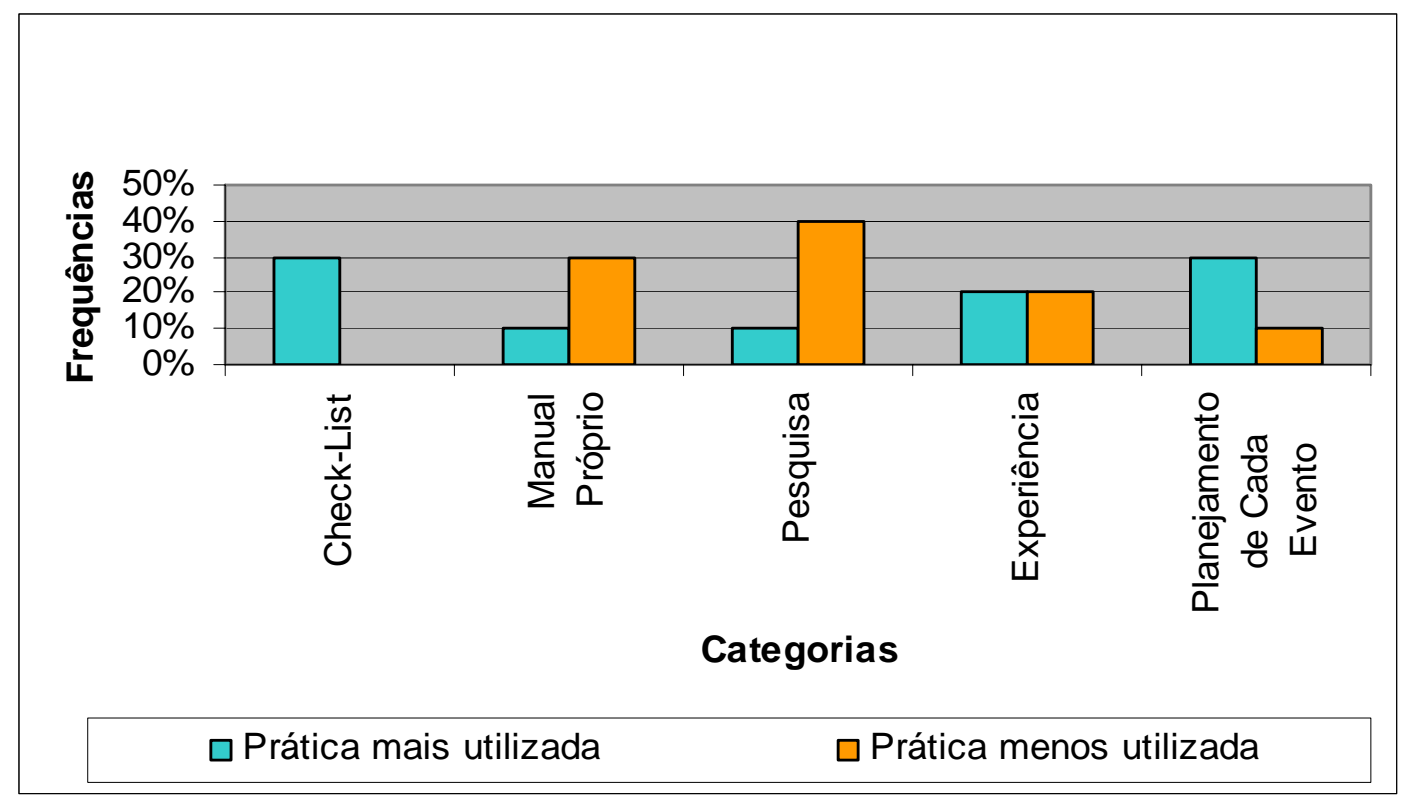

Figura 21: Relação das Práticas Utilizadas

Pesquisas e Manual próprio para cada evento, praticamente, não são utilizados ampliando a chance de riscos e dificultando o seu gerenciamento.

Os eventos realizados em Brasília são considerados, pelos entrevistados, conforme FIGURA 22, bons ou regulares. 


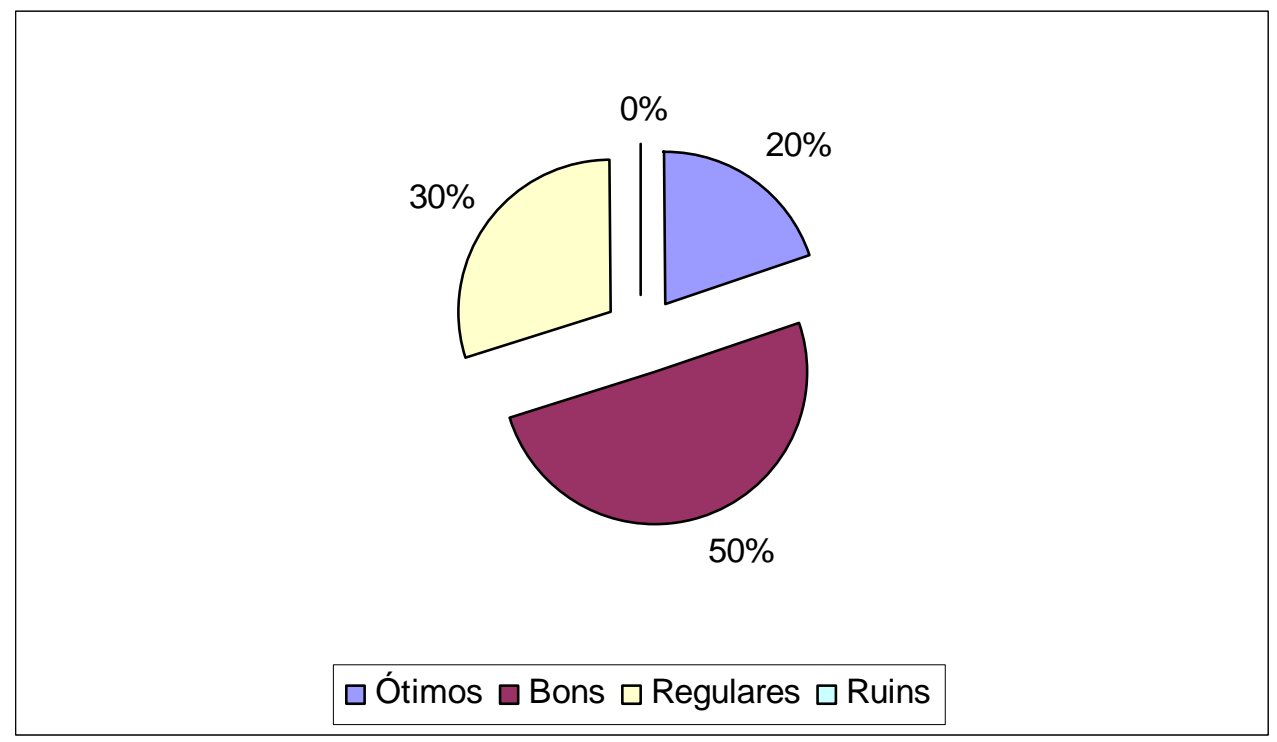

Figura 22: Classificação dos eventos de Brasília

Os próprios gestores percebem ter muito a melhorar. Apenas 20\% dos entrevistados consideram ótimos os eventos em Brasília.

Conclui-se que os profissionais do mercado aprendem a lidar com situações adversas na prática do seu cotidiano de trabalho. Ou seja, trabalha-se com referências de experiências anteriores e não com o planejamento detalhista ou com fundamentação teórica. É preciso fundamentar o planejamento para que os riscos sejam minimizados, numa atuação preventiva, e não corretiva. O foco da gestão de eventos não se limita a apagar incêndios, mas fazer com que eles não ocorram. Pensar analiticamente, como a lei da física, que enuncia que para toda ação tem-se uma reação de mesma intensidade e de sentido contrário. Um evento que irá acontecer precisa ter elencado as ameaças e as oportunidades, onde se poderão prever ações corretivas ainda na fase de planejamento. Um exemplo comum de insucesso em eventos é o rompimento de vínculo de patrocinador durante o planejamento do evento. Um contrato com cláusulas que prevejam este fato, bem como abastecer o patrocinador de informações sobre as fases em andamento, podem reverter um possível cancelamento conquistando a permanência, a fidelidade e a satisfação do patrocinador. 
São necessárias a administração de detalhes e riscos com a utilização de técnicas que possam diminuir o grau de improvisação dos profissionais da área. Importantes gestores de eventos em Brasília afirmam aplicar como técnicas o Check-list e o brainstorming e demonstram interesse em conhecer outras que minimizem riscos. 


\section{Manual Prático para Gestão de Riscos em Eventos}

\subsection{Passos no Gerenciamento de Riscos}

É importante saber que não é possível prevenir tudo o que pode ocorrer em um evento, mas é possível minimizar os imprevistos que poderão se transformar em riscos. Todos que participam da elaboração, do planejamento e da realização de um evento deveriam seguir alguns procedimentos básicos e fazer uma análise mais profunda dos imprevistos e riscos encontrados. O gerenciamento de risco estruturase da seguinte maneira: a etapa inicial é a identificação do risco, ou seja, encontrar as fontes de risco no projeto; por conseguinte, está o desenvolvimento de uma resposta, em que se tem a definição do risco em termos de probabilidade e impacto e a elaboração de uma estratégia para reduzir o risco encontrado; por último, há o controle, quando se implementam as estratégias e verificam-se seus resultados, além de dar continuidade ao monitoramento de novos riscos ao projeto.

Abaixo estão descritos os passos para o gerenciamento de risco de acordo com o ciclo PDCA, destacando-se cada uma das etapas, as quais serão analisadas em conjunto com a ferramenta SWOT para os efeitos desta gestão.

Estas diretrizes estão subdivididas em cinco etapas:

1ª Etapa: Identificação dos Riscos - Planejamento

Para se poder planejar e estabelecer uma estratégia na gestão de riscos, é importante:

a. Conhecer as metas a ser realizada no evento;

b. Formar uma equipe qualificada;

c. Identificar os riscos para minimizar suas conseqüências. 
Os objetivos da Identificação de Risco são:

- Verificar se o impacto é alto ou baixo;

- Analisar quaisquer tipos de ameaças ao desenvolvimento do projeto;

- Conhecer as vulnerabilidades;

- Identificar os riscos de cada etapa durante o planejamento;

- Identificar os riscos de cada departamento envolvido;

- Gerenciar as ameaças dos riscos identificados.

Para identificar os riscos são utilizadas as técnicas:

Brainstorming - Tempestade de Idéias: têm-se as seguintes etapas para facilitar o andamento do processo:

- Conduzir uma sondagem administrativa para determinar os grupos externos e internos que devem participar dessas avaliações de risco;

- Identificar a pessoa responsável pela Avaliação de Risco, a qual ajudará a identificar as ameaças e riscos dentro de sua área interna e lou externa;

- $\quad$ Fazer com que cada responsável da equipe envie ao administrador geral uma lista escrita de todos os riscos potenciais. Realizar uma pesquisa antecipada ajuda a administrar o tempo durante a reunião.

- $\quad$ Fazer uma lista geral com todas as prévias informações de ameaças enviadas. Fazer a lista subdividida por cada seção;

- $\quad$ Fazer com que as reuniões tenham o maior número de pessoas. 
Brain-writing - Tempestade de Idéias Escritas:

- Gerar comprometimento com as soluções;

- Substituir a verbalização por registros escritos;

- É um processo democrático: todos possuem igual possibilidade de participação, inclusive as pessoas mais tímidas e reservadas;

Na TABELA 6 é proposto modelo de formulário para realização do Brainwriting a ser distribuída para todas as pessoas do grupo, onde cada um escreve e identifica, individualmente, uma ou várias idéias para serem analisadas na solução do problema.

\section{TABELA 6}

Formulário de Brain-writing

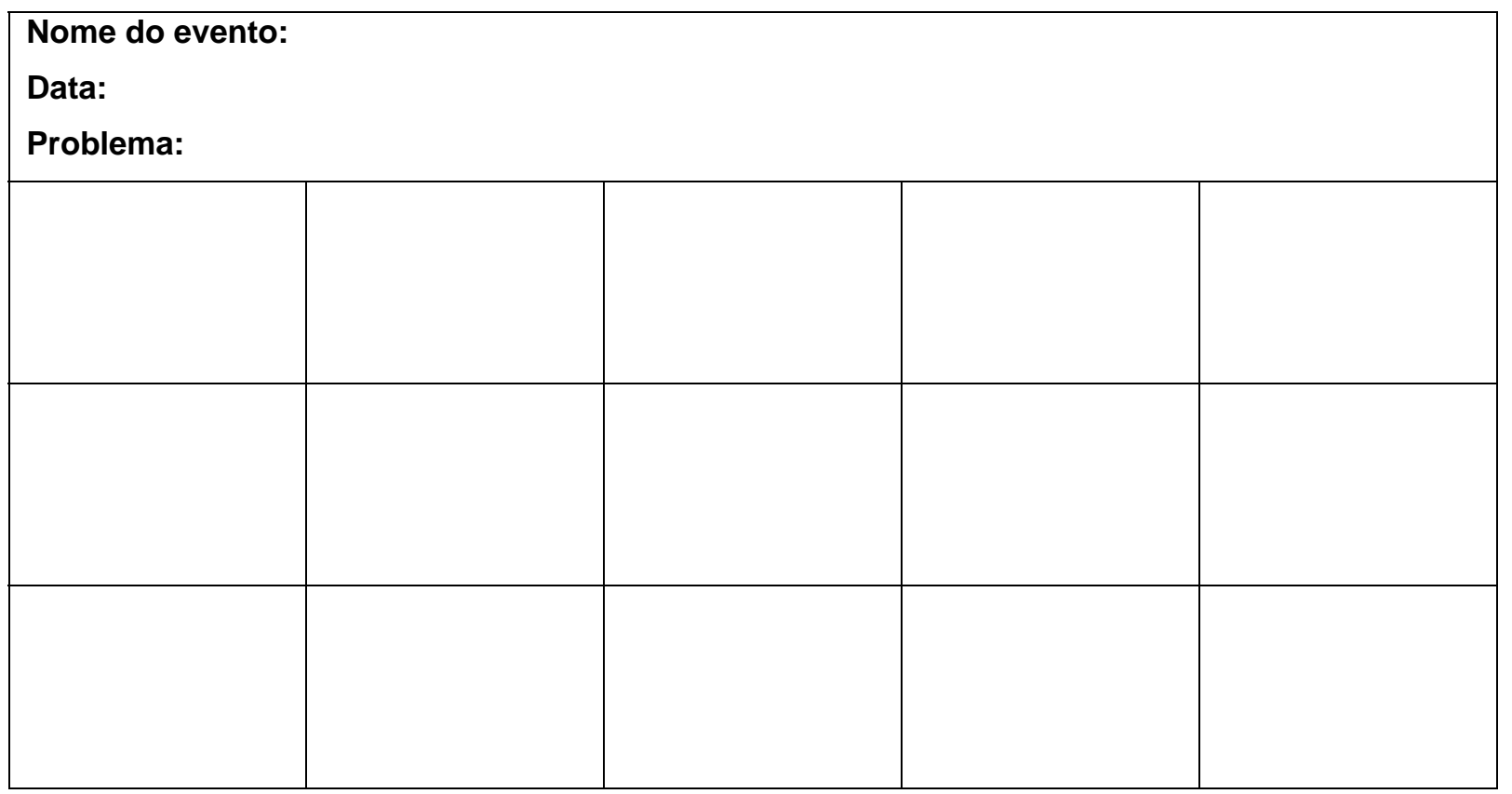

Fonte: Disponível em: <http://www.creatingminds.org/tools/brainwriting.htm>. Acesso em: 13 ago. 2005.

Nesta etapa, é importante entender que não se deve tentar encontrar ou avaliar as soluções de todos os riscos; o objetivo é apenas identificá-los. 


\section{$\underline{2^{a} \text { Etapa: Avaliação dos Riscos- Planejamento }}$}

Depois de identificados os riscos, o segundo passo é avaliá-los:

a. A maior dificuldade é determinar e emitir os critérios, os juízos, e as interpretações apropriados sobre os impactos e ameaças identificadas.

b. Mensurar a probabilidade de risco: verificar se o impacto é alto ou baixo; analisar as possíveis etapas do processo que poderiam oferecer quaisquer tipos de ameaças ao desenvolvimento do projeto.

c. As atividades e idéias pré-determinadas durante as reuniões iniciais serão afuniladas com as perguntas da técnica $5 W 2 H$. Estas são algumas sugestões, básicas, mas são perguntas importantes; cabe lembrar, ainda, que cada evento é único, havendo modificações de acordo com cada tipo:

- Why. Por que este evento está sendo realizado: o objetivo; por que se pensa que está preparado para realizar este evento;

- Who. Quem serão os beneficiários. Identifique quem serão os assistentes e qual será o seu público (aqui entra a demografia dos participantes). Quem são os nossos concorrentes. Quem sofreria a perda? Sua empresa, seu cliente, os empregados, os terceirizados? E, de quanto seria a perda para cada integrante?

- When. Quando será realizado o evento. Essa informação determinará se existe local, se esse dia é um feriado, se a data está bem definida; quando foi feito outro evento parecido;

- Where. Onde será o evento. Informará se o lugar é bom, se estão preparados para atender os objetivos e especificações do evento; onde foi realizado outro evento com características semelhantes; 
- What. Que se espera deste evento, o que espera o cliente, o que espera os que atenderão, o que espera o público. Que perdas podem acontecer neste evento: propriedade física, pessoal, imagem pública ou seguro contra responsabilidades. Exemplos: equipamento, material, espectadores. O que poderia ocasionar uma perda? Isto pode ser desde roubo até vandalismo, ocasionado pela queda de eletricidade.

- How. Como será realizado este evento. Como serão treinados os voluntários? Como produzir um evento de sucesso?

- How Much. Quanto/Quanto custa. Quanto ficará o orçamento do evento? Os recursos disponíveis são suficientes? Gerenciar o controle de custos.

Na TABELA 7 é proposto formulário para realizar as perguntas iniciais

\author{
TABELA 7
}

Controle 5W2H

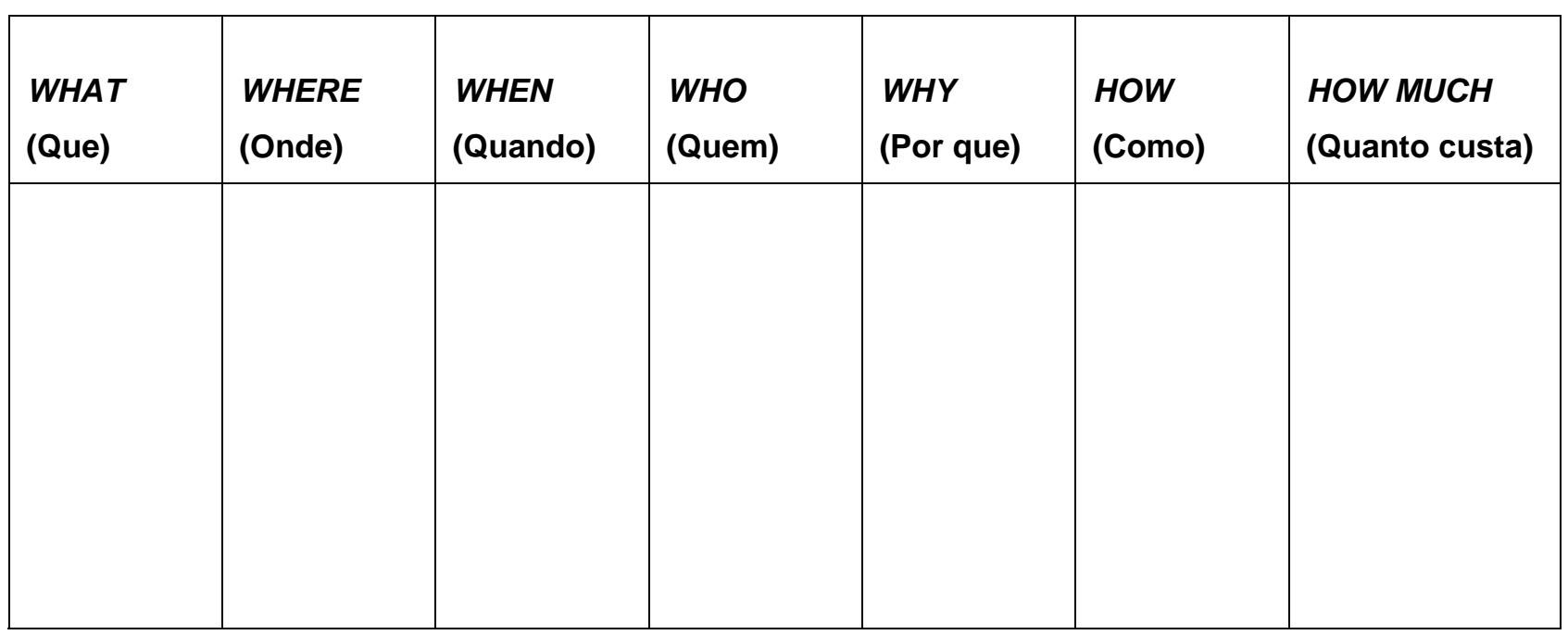

d. Neste processo análises qualitativa e quantitativa ajudam na verificação específica de dados com o propósito de ver os possíveis incidentes e a potencialidade da gravidade dos impactos de riscos para depois filtrar o que não é risco. 
Análise Qualitativa serve para a detecção e classificação dos riscos os quais serão avaliados com o propósito de calcular a probabilidade e o impacto da ocorrência em um evento. Possui como ferramentas a Matriz de Classificação de Risco por Probabilidade-Impacto e o Formulário prático para Classificação de Riscos.

Matriz de Classificação de Risco por Probabilidade-Impacto: Esta análise permite classificar os riscos para depois analisar a probabilidade e o impacto dos riscos objetivando reduzir ou minimizar suas conseqüências.

Na FIGURA 23 é apresentado modelo da matriz de classificação de riscos por probabilidade-impacto para realizar uma análise qualitativa.

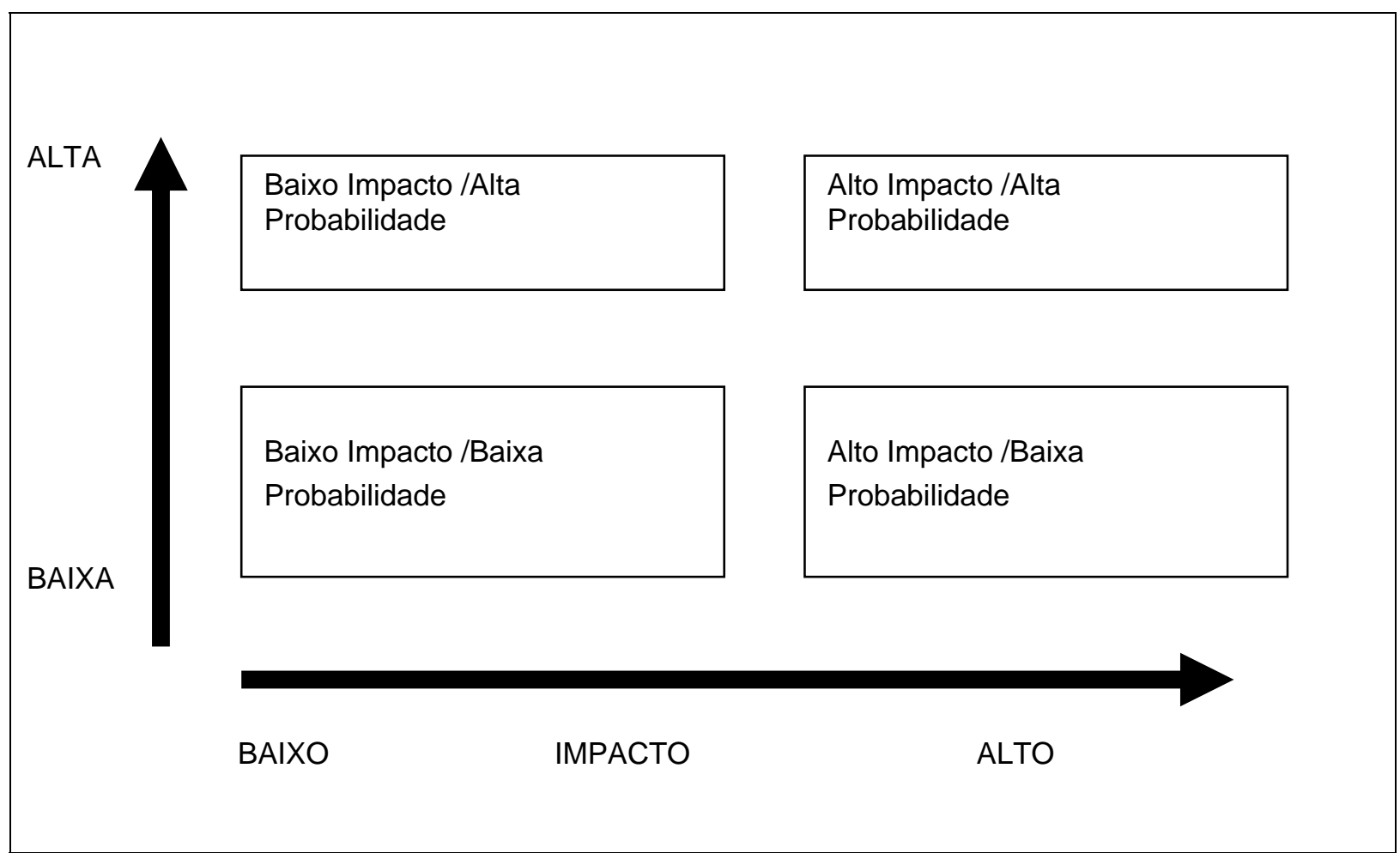

Figura 23: Matriz de Classificação de Risco por Probabilidade-Impacto

Fonte: MAXIMIANO, Antônio César Amaru. Introdução à Administração. 6a Edição. São Paulo: Atlas, 2004.

A TABELA 8 representa um formulário prático a ser utilizado para detectar e atribuir pesos à probabilidade e impacto de riscos identificados. 
TABELA 8

Formulário prático para Classificação de Riscos

\begin{tabular}{|l|lllcc|}
\hline \multicolumn{1}{l}{ Restrições } & Baixo-Baixo & Baixo & Médio & Alto & Alto-Alto \\
\hline Porcentagem & 0,05 & 0,20 & 0,40 & 0,60 & 0,80 \\
\hline Custo & & & & \\
Tempo & & & & \\
Qualidade & & & & \\
Clima & & & & \\
No. Pessoas & & & \\
Local & & & \\
\hline
\end{tabular}

Fonte: MAXIMIANO, Antônio César Amaru. Introdução à Administração. 5a Edição. São Paulo: Atlas, 2000.

A Análise Quantitativa tem como enfoque analisar cada risco e o impacto que pode ocasionar, caso aconteça. Para isso, existem ferramentas práticas que ajudam neste processo. Os dados históricos de eventos devem ser considerados e analisados. Suas ferramentas são:

Análise da Árvore de Decisões: esta técnica pode também ser utilizada em imprescindível corrigir o problema e a complexidade das decisões, conforme demonstra FIGURA 24. 


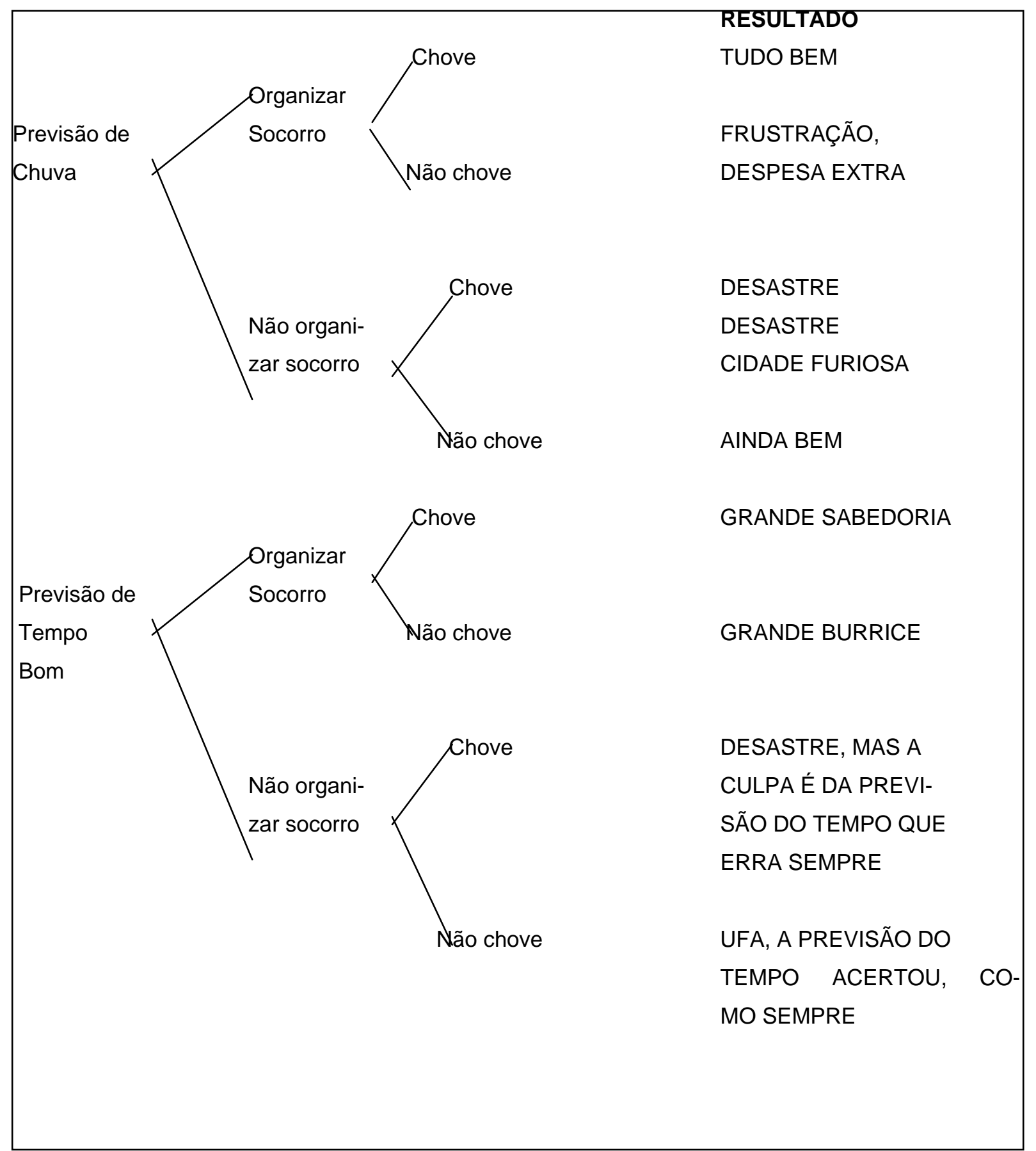

Figura 24: Árvore de Decisões

Fonte: MAXIMIANO, Antônio César Amaru. Introdução à Administração. 5a Edição. São Paulo: Atlas, 2000.

A análise quantitativa de riscos, assim como a análise qualitativa, avalia cada risco e os impactos sobre os objetivos do evento. Porém, a primeira análise quantifica a exposição do evento ao risco, detalha as intersecções entre os riscos e avalia os possíveis resultados. O enfoque é verificar e localizar os riscos mais 
relevantes, os quais não podem ser ignorados, identificando aqueles que requerem atenção e urgência bem como aqueles que podem ser analisados com maior passo. Todas as informações, coletadas por meio das pesquisas e dos resultados com técnicas aplicadas, bem organizadas, sistematizadas e atualizadas são dados cruciais na organização, controle e monitoramento de atividades futuras, que ajudarão na melhoria da gestão de riscos.

Fazer a primeira análise no planejamento com a ferramenta SWOT a qual terá todas as informações da $1^{\mathrm{a}}$ e $2^{\mathrm{a}}$ Etapas coletadas e pesquisadas objetivando diferenciá-los no esquema da avaliação interna e externa a serem consideradas no gerenciamento.

Para a utilização da ferramenta SWOT é conveniente que se adote e responda às perguntas levando em conta os Pontos fortes e os Pontos fracos que são parte da análise interna do projeto ou organização; e as Oportunidades e as Ameaças são parte da análise externa do evento ou organização.

\section{Strengths ou Pontos Fortes}

- Quais são as suas vantagens competitivas?

- O que você faz bem?

- A quais pesquisas relevantes você tem acesso?

-Quais as habilidades que as outras pessoas /entidades /empresas identificam em você?

- Pense em suas habilidades e as compare com os seus concorrentes

\section{Weaknesses ou Pontos Fracos}

- Onde você pode melhorar?

- O que você não faz bem feito?

- O que você deveria evitar?

- Outras pessoas percebem os seus pontos fracos?

- Os concorrentes são melhores que você? (Seja verdadeiro) 


\section{Opportunities ou Oportunidades}

- Você percebe as oportunidades no seu mercado?

- Quais são as modalidades da sua área das quais você está sujeito?

Fatos que podem resultar em oportunidades úteis são: conhecer as mudanças de tecnologia, de mercado, das políticas de governo, de estilo de vida, de perfil da população, de local, entre outros.

\section{Threats ou Ameaças}

- Quais são os obstáculos que você enfrenta?

- O que o seu concorrente está desenvolvendo?

- As mudanças de tecnologia estão ameaçando o seu posicionamento no mercado?

- Você tem problema de fluxo de caixa?

- Você tem dívidas?

Goldblatt (1997) propõe modelo, conforme TABELA 9, a serem observados na aplicação da ferramenta SWOT. E na TABELA 10, é proposto formulário básico a ser utilizado pelos gestores de eventos. 
TABELA 9

Exemplo Análise SWOT

\begin{tabular}{|c|c|c|}
\hline \multicolumn{2}{|l|}{ S = STRENGTHS } & \multirow{8}{*}{$\begin{array}{l}\text { Condições } \\
\text { existentes }\end{array}$} \\
\hline 1.Empregados treinados & Interno & \\
\hline 2.Evento bem conceituado & Externo & \\
\hline 3.Bom fundos de dinheiro & Interno & \\
\hline \multicolumn{2}{|l|}{ W = WEAKNESSES } & \\
\hline 1.Falta de recursos Interno & Interno & \\
\hline 2.Ausência de Histórico de relações pública & Externo & \\
\hline 3.Pessoal não treinado & Interno & \\
\hline \multicolumn{2}{|l|}{ O = OPPORTUNITIES } & \multirow{7}{*}{$\begin{array}{l}\text { Condições } \\
\text { Previstas }\end{array}$} \\
\hline $\begin{array}{l}\text { 1.Celebração simultânea de um evento } \\
\text { complementar }\end{array}$ & Externo & \\
\hline 2.O momento do evento é congruente com & Interno & \\
\hline a alocação dos recursos orçamentários & & \\
\hline \multicolumn{2}{|l|}{$T=$ THREATS } & \\
\hline 1.Clima & Externo & \\
\hline 2. Mudança de Diretório do evento & Interno & \\
\hline
\end{tabular}

Fonte: GOLDBLATT, Joe Jeff. Special Events Best Pratices in Modern Event Management. New York: John Wiley \& Sons, Inc., 1997. 
TABELA 10

Exemplo de formulário para Análise SWOT

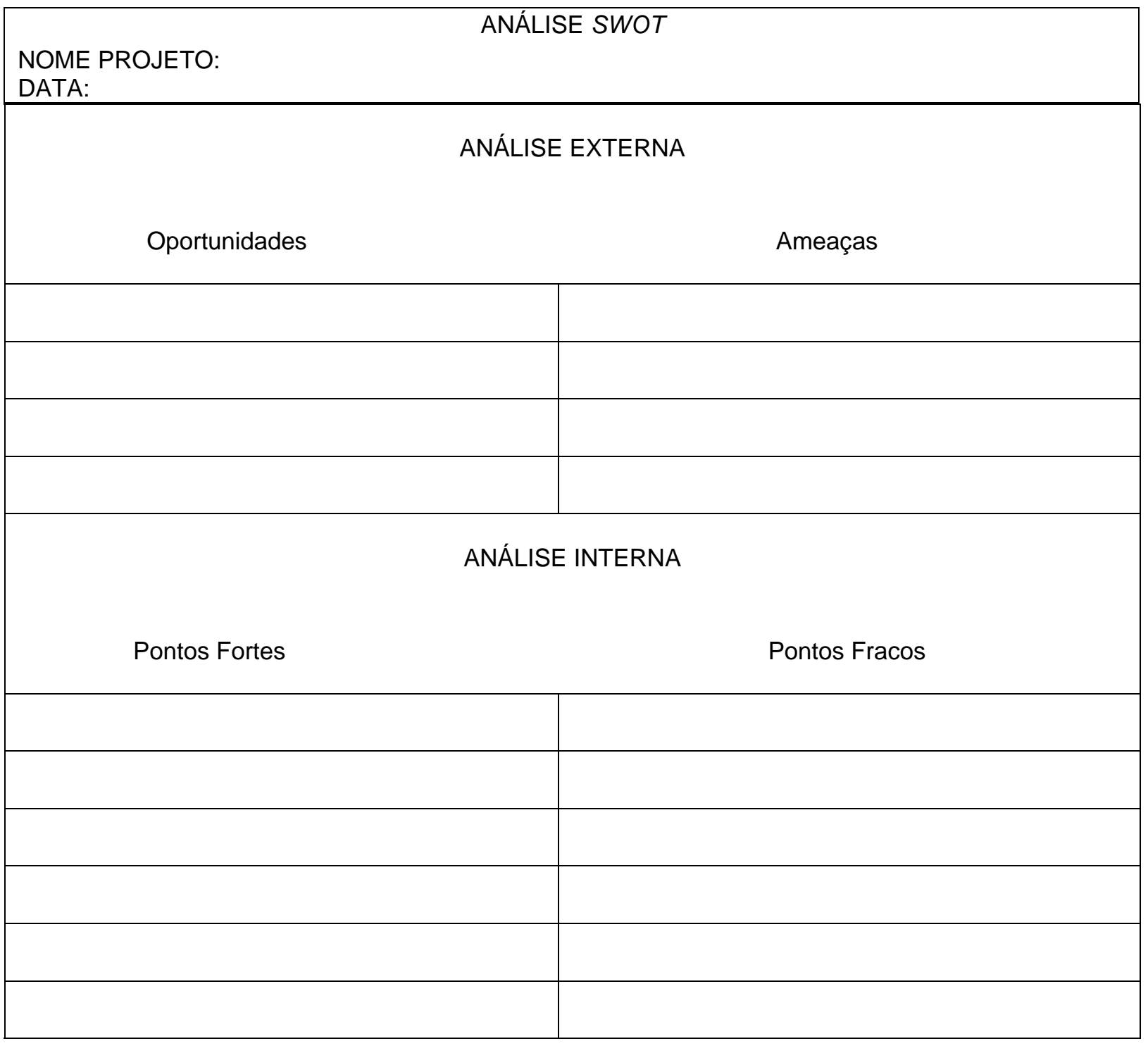

$\underline{3^{a} \text { Etapa: Ação de Tarefa - Execução /Fazer }}$

Após a segunda etapa, onde a análise de risco classifica e prioriza os riscos como internos e externos com a utilização da ferramenta SWOT, deve-se fazer com que o processo de execução caminhe em sintonia com os objetivos desejados. Porém: 
d. Deve-se elaborar Plano de Ação;

e. O Plano de ação consiste em programar uma lista de ações onde exista uma seqüência de atividades necessárias ao longo do tempo. Nesta fase se considera e prioriza as possíveis probabilidades de risco;

f. As ações de um plano devem ser propostas por pessoas envolvidas em processos anteriores juntamente com os responsáveis por implementar as ações durante o processo e essas devem ser pessoas experientes;

g. Todas as tarefas, atividades e ações devem estar classificadas dentro da análise SWOT externa e interna. Desta forma será possível determinar o grau de risco de cada atividade ou tarefa avaliando quais representariam ameaça ao evento;

h. O objetivo desta etapa e estar seguro e trabalhar com um instrumento para execução e controle.

As ferramentas práticas utilizadas para o Plano de Ação são: o Check-list, a Lista de Atividades, a Tabela de Atividades e Precedências, o Diagrama de Precedências e a Análise SWOT que é feita quando todas as atividades, tarefas e ações foram identificadas.

\section{Check-List:}

São listas de verificação que podem ser utilizadas nas diferentes etapas e de acordo com o critério de cada organizador. Um exemplo do Check-list, o qual está elaborado com foco no ciclo PDCA, será apresentado no final do manual, englobando as quatro etapas do ciclo. 
Lista de Atividades:

- Instrumento que identifica as atividades necessárias, conforme exemplo da TABELA 11, os objetivos de cada atividade e do evento como um todo e define atribuições a cada departamento ou gestor a ele envolvido.

- Deve-se elaborar uma lista exaustiva de atividades por meio da técnica do brainstorming. Desta forma, aumenta-se a possibilidade de não esquecer de identificar nenhuma delas.

TABELA 11

Exemplo Lista de Atividades de uma Olimpíada

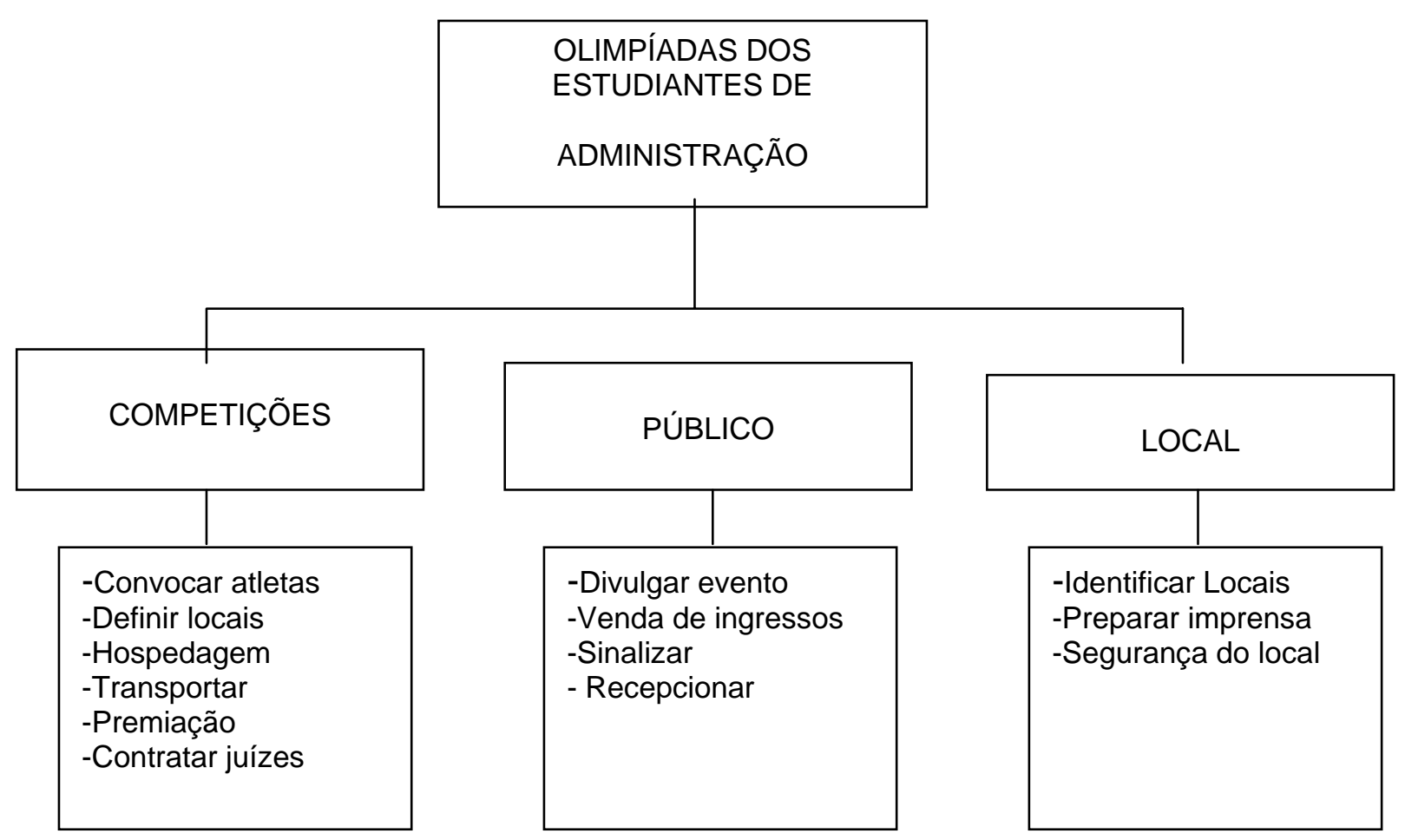

Fonte: MAXIMIANO, Antônio César Amaru. Introdução à Administração. 6ª Edição. São Paulo: Atlas, 2004. 
Tabela de Atividades e Precedências:

Esta tabela tem por objetivo estabelecer a duração de cada atividade. Assim, em conta:

- O seqüenciamento das atividades de acordo com a precedência, determinada pela lógica ou decisão dos organizadores;

- Esta tabela deve ser como o auxílio do Diagrama de Precedências, TABELA 13 elaborada.

Para facilitar a execução, é apresentado, TABELA 12, um exemplo de formulário.

TABELA 12

Exemplo da Tabela de Atividades e Precedências

\begin{tabular}{|c|c|c|c|}
\hline \multicolumn{4}{|c|}{$\begin{array}{l}\text { Evento: Olimpíada dos estudantes de Administração } \\
\text { Data: }\end{array}$} \\
\hline ATIVIDADE & DURAÇÃo & $\begin{array}{c}\text { ATIVIDADE } \\
\text { PRECEDÊNCIA }\end{array}$ & RESPONSÁVEL \\
\hline Convocar atletas & 1 mês & 1 & \\
\hline Divulgar evento & 9 meses & 2 & \\
\hline Organizar local & 6 meses & 3 & \\
\hline Contratar juízes & 1 mês & 4 & \\
\hline Segurança & 1 mês & 6 & \\
\hline Definir chaves & 1mês & 5 & \\
\hline Realizar competição & 1 semana & todas & \\
\hline
\end{tabular}

Fonte: MAXIMIANO, Antônio César Amaru. Introdução à Administração. $6^{a}$ Edição. São Paulo: Atlas, 2004.

A última ferramenta a ser utilizada no plano de ação será o Diagrama de Precedências. Um seqüenciamento, conforme TABELA 12, deverá estabelecer a ordem em que as atividades serão realizadas. 


\section{Diagrama de Precedências:}

O seqüenciamento mostra a ordem que as atividades serão realizadas e este processo responde ao seguinte:

- Para que a atividade possa acontecer, quais outras devem ter sido realizadas?

- Uma vez que a atividade tenha sido realizada, quais outras devem ocorrer em seguida?

\section{TABELA 13}

Exemplo do Diagrama de Precedências

São as precedências das atividades:

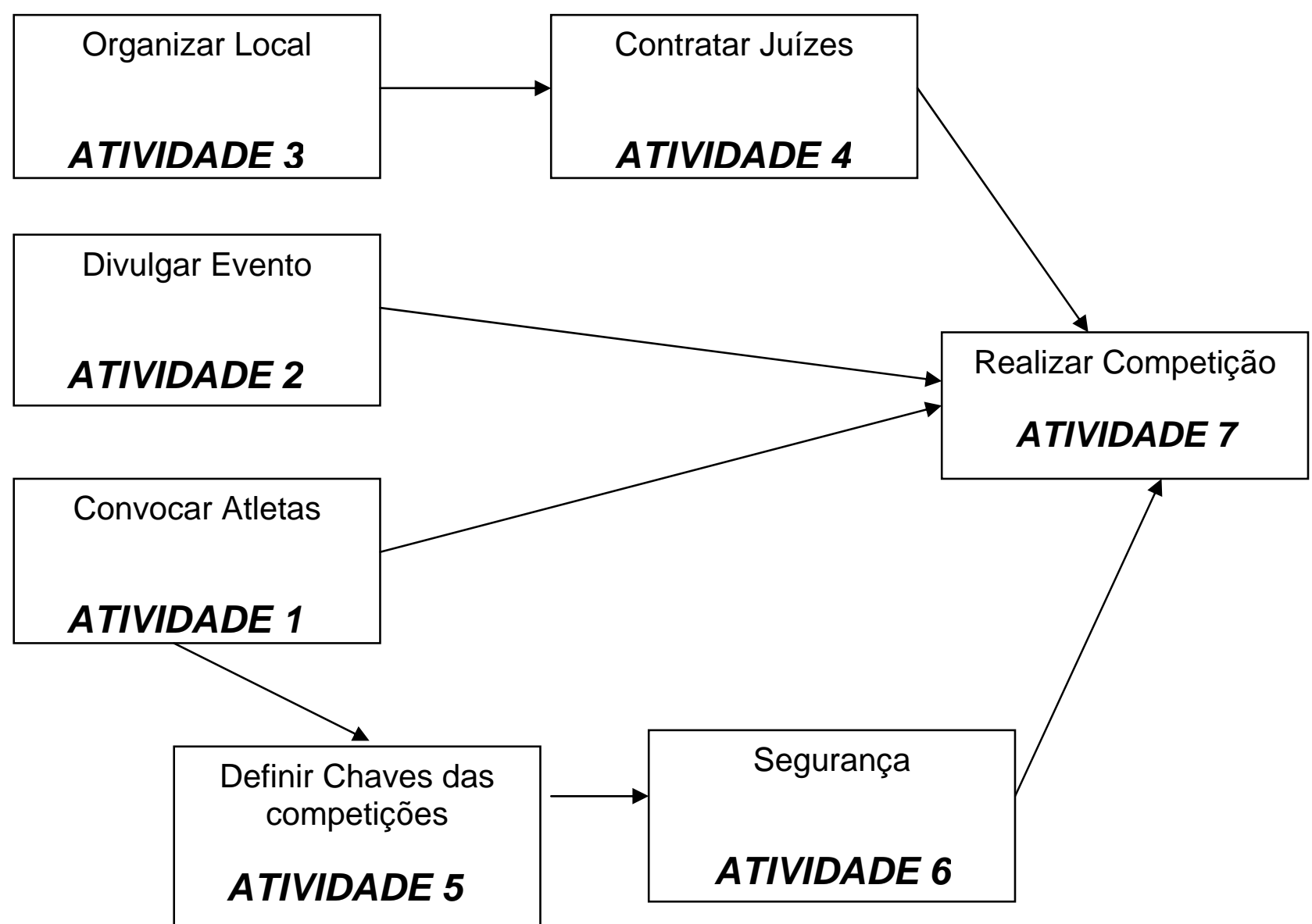

Fonte: MAXIMIANO, Antônio César Amaru. Introdução à Administração. 6ª Edição. São Paulo: Atlas, 2004. 


\section{Etapa: Ação de Verificação de Riscos - Controle}

O controle é a implementação do que foi acordado na fase do planejamento dos riscos e da distribuição das atividades. Os objetivos desta etapa são:

- Monitorar e ter informações sobre o grau de realização das estratégias de ação, sobre os resultados, os riscos e as oportunidades das atividades;

- $\quad$ Produzir e usar informações para tomar decisões sobre a execução e atividades e sobre os objetivos;

- $\quad$ Se existe a necessidade, corrigir fatores internos e externos;

- Verificar se o objetivo está sendo cumprido.

Para esta etapa a sugestão é utilizar as ferramentas: o $5 \mathrm{~W} 2 \mathrm{H}$, o Check-list, as Sete Perguntas Capitais e a Análise SWOT. O 5W2H e o SWOT já foram construídas na $2^{a}$ etapa Avaliação de Risco e um modelo do Check-list será apresentada no final do manual.

Esta etapa geralmente é operacionalizada com reuniões com a equipe. $\mathrm{O}$ Gestor de evento tem a opções de utilizar uma ou todas três ferramentas de perguntas: o 5W2H, o Check-list e as Sete Perguntas Capitais. A ferramenta deve focar no controle de riscos, com o fim de verificar e assegurar a realização dos objetivos e identificar a necessidade ou não de modificá-los. Este ciclo é repetido constantemente até que os processos desejados fiquem satisfatórios. Os problemas passam a ser sempre esperados, porém os desafios serão variáveis. E, às vezes, durante o caminho outros problemas se apresentarão. As ferramentas de perguntas ajudam a ter uma visão do que está acontecendo de forma regular e assim prepara para o que deve ser feito. Uma forma de controlar situações e imprevistos.

O controle pode ser feito pelas Sete Perguntas Capitais proposto por Campos (1992, p.56). Elas são capitais porque qualquer resposta negativa é um "pecado capital" para o resultado e para a realização de qualquer planejamento. 


\section{Sete Perguntas}

- (P) Você tem certeza de que cada operador do evento conhece o objetivo de seu trabalho, a meta, de tal forma que possui um critério para saber se seu trabalho está bom ou ruim?

- $\quad(P)$ Você tem certeza de que todas as pessoas envolvidas no evento sabem quais são os procedimentos de operação?

- $\quad$ (D) Você tem certeza de que todas as pessoas estão bem treinadas?

- (D) Você tem certeza de que todos os procedimentos padronizados estão sendo cumpridos?

- (D) Você tem certeza de que os dados utilizados no gerenciamento de riscos estão atualizados e certos?

(C) Você tem certeza de que as pessoas especializadas estão realmente cumprindo as normas de inspeção?

- (A) Você tem certeza de que todas as pessoas sabem o que fazer quando acontece um problema, ou sabem onde encontrar ajuda para resolver o problema?

\section{5a Etapa: Ação Corretiva - Agir}

Essa última etapa consiste na correção de alternativas, que porventura, não resultaram em boas oportunidades e vantagens durante a organização do evento.

As técnicas a serem utilizadas nessa etapa são: a Análise do Campo de Forças; a Árvore de Decisões, apresentada na $2^{a}$ etapa; o Check-list e o SWOT.

\section{Análise do Campo de Forças:}

Para definir o Campo de Forças deve-se separar em gráfico as forças favoráveis e contrarias conforme exemplo TABELA 14 buscando analisar determinada situação e implantar uma solução por meio da verificação das forças que prevalecem sob as outras, conforme sugere Maximiano (2000). 
TABELA 14

Exemplo da Análise do Campo de Forças

Problema-Situação: Legalização de Hotéis /Cassinos e Jogo

FORÇAS

FAVORÁVEIS

Lobby

- Turismo

- Criação de Empregos

- Abertura de mais Hotéis

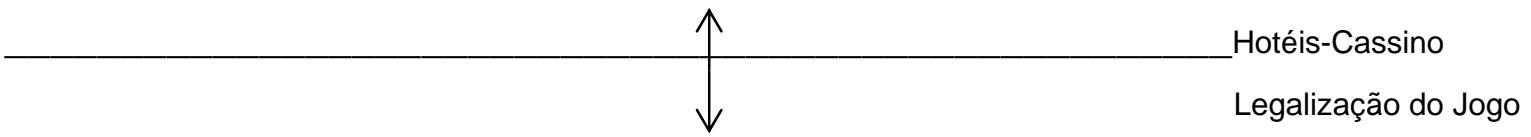

- Incentivo a apostas com dinheiro

- Incentivo a competição entre as pessoas / Individualidade

- Incentivo ao Jogo

- Igreja

- Receita Federal

FORÇAS

CONTRÁRIAS

Fonte: MAXIMIANO, Antônio César Amaru. Introdução à Administração. 5a Edição. São Paulo: Atlas, 2000.

\section{Check-List}

A partir do ciclo do PDCA, a lista de verificação ou Check-list, conforme exemplo na TABELA 15, estará possibilitando a condução /gerenciamento de um evento:

TABELA 15

Exemplo de Check-list

\begin{tabular}{|l|l|l|}
\hline SIM & NÃO & 1-2. ETAPA PLANAJAMENTO /IDENTIFICAÇÃO \\
\hline & & A missão foi comunicada a todos? \\
\hline & & Uma avaliação global de riscos foi realizada? \\
\hline
\end{tabular}




\begin{tabular}{|c|c|c|}
\hline & & $\begin{array}{l}\text { As principais partes interessadas e afetadas foram adequadamente } \\
\text { envolvidas? }\end{array}$ \\
\hline & & $\begin{array}{l}\text { Toda informação relevante necessária para prosseguir o evento esta } \\
\text { disponível e organizada? }\end{array}$ \\
\hline & & $\begin{array}{l}\text { Todos estão informados dos procedimentos básicos da elaboração, } \\
\text { planejamento e realização do evento? }\end{array}$ \\
\hline & & $\begin{array}{l}\text { Foi realizado um diagnóstico perceptivo para produzir idéias, opiniões } \\
\text { por escrito? }\end{array}$ \\
\hline & & $\begin{array}{l}\text { Foi realizada a Análise qualitativa e quantitativa? } \\
\text { Os riscos foram classificados? }\end{array}$ \\
\hline & & Avaliaram o impacto dos riscos? \\
\hline & & Você tem alternativas de estratégias? \\
\hline SIM & NÃO & 3. ETAPA DE EXECUÇÃO \\
\hline & & Quais são suas ações específicas? \\
\hline & & A liderança é reconhecida pela equipe? \\
\hline & & A equipe requer treinamento específico? \\
\hline & & Os fornecedores estão integrados ao projeto? \\
\hline & & A equipe está capacitada na solução de problemas? \\
\hline & & O orçamento está específico para cada seção? \\
\hline & & As tarefas estão determinadas? \\
\hline SIM & NÃO & 4. ETAPA DE VERIFICAÇÃO /CONTROLE \\
\hline & & Foi feito o monitoramento das ações específicas? \\
\hline & & Existem resultados das atividades? \\
\hline & & Sabem quais são os fatores internos e externos a serem corrigidos? \\
\hline & & Está sendo avaliado o desempenho? \\
\hline & & Tem uma visão dos imprevistos? \\
\hline & & Os procedimentos estão sendo controlados? \\
\hline & & As normas de inspeção estão sendo controladas? \\
\hline & & Tem certeza que as pessoas estão sendo treinadas corretamente? \\
\hline & & As pessoas sabem quais são os processos de operação? \\
\hline SIM & NÃO & 5. ETAPA CORRETIVA IAVALIAÇÃO \\
\hline
\end{tabular}




\begin{tabular}{|l|l|l|}
\hline & Todas as alternativas foram analisadas quando a decisão foi tomada? \\
\hline & & Foram listadas todas as alternativas para decisão? \\
\hline & As técnicas foram utilizadas corretamente? \\
\hline & A comunicação entre a equipe era estável? \\
\hline & Surgiram dúvidas durante o processo que não foram esclarecidas? \\
\hline & Houve mudança de responsabilidades? \\
\hline & Foi realizada uma reunião de análise dos resultados? \\
\hline & Qual foi o grau de satisfação dos clientes? \\
\hline & Foi feito o gerenciamento de riscos durante todos os processos? \\
\hline
\end{tabular}

\subsection{Roteiro Resumido do Manual Prático}

Na TABELA 16, são relacionadas as ações ou passo a passo das diretrizes práticas, que reúne sugestões de ferramentas de alguns autores, acrescentando a proposta desse objeto de estudo, ou seja, unir o PDCA ao SWOT para gerenciamento dos riscos. 
TABELA 16

Roteiro Resumido do Manual Prático

\begin{tabular}{|c|c|c|c|}
\hline \multicolumn{4}{|c|}{ ETAPAS E FERRAMENTAS - GERENCIAMENTO DE RISCO } \\
\hline CICLO PDCA & ETAPAS & $\begin{array}{c}\text { PASSO A PASSO DAS } \\
\text { ATIVIDADES }\end{array}$ & $\begin{array}{c}\text { FERRAMENTAS DAS } \\
\text { DIRETRIZES }\end{array}$ \\
\hline \multirow{2}{*}{$\begin{array}{c}\text { P } \\
\text { PLANEJAR }\end{array}$} & & - Identificar Riscos & $\begin{array}{l}\text { 1.Brainstorming } \\
\text { 2.Brain-writing }\end{array}$ \\
\hline & & $\begin{array}{c}\text { - Avaliação de } \\
\text { Riscos }\end{array}$ & $\begin{array}{l}\text { 3. } 5 \mathrm{~W} 2 \mathrm{H} \\
\text { 4.Probabilidade-Impacto } \\
\text { 5.Árvore de decisões } \\
\text { 6. Análise SWOT }\end{array}$ \\
\hline $\begin{array}{c}\text { D } \\
\text { FAZER }\end{array}$ & & - Ação de Tarefas & $\begin{array}{l}\text { 7. Ckeck-list } \\
\text { 8.Lista Atividades } \\
\text { 9.Tabela de Atividades e } \\
\text { Precedência } \\
\text { 10.Diagrama Precedências } \\
\text { 11.Análise SWOT }\end{array}$ \\
\hline $\begin{array}{c}\text { C } \\
\text { CONTROLE } \\
\text { VERIFICAR }\end{array}$ & & $\begin{array}{c}\text { - Controle de } \\
\text { Riscos }\end{array}$ & $\begin{array}{l}\text { 12. } 5 \text { W2H } \\
\text { 13. Ckeck-list } \\
\text { 14. "Sete Perguntas Capitais" } \\
\text { 15. Análise SWOT }\end{array}$ \\
\hline $\begin{array}{c}\text { A } \\
\text { AGIR } \\
\text { CORREGIR }\end{array}$ & & $\begin{array}{l}\text { - Ação Corretiva } \\
\text { (Avaliação) }\end{array}$ & $\begin{array}{l}\text { 16. Campo de Forças } \\
\text { 17.Árvore de Decisões } \\
\text { 18. Ckeck-list } \\
\text { 19. Análise SWOT }\end{array}$ \\
\hline
\end{tabular}




\section{CONCLUSÕES FINAIS}

Brasília dispõe de infra-estrutura turística consolidada e em processo de expansão com um grande potencial para sediar eventos de grande porte. Dessa forma, deve-se entender a importância de proporcionar aos profissionais do mercado condições para o desenvolvimento gerencial dos mesmos. A principal motivação neste trabalho foi pesquisar se os gestores de eventos em Brasília utilizavam ferramentas práticas no planejamento de um evento, em vistas a minimizar os possíveis riscos. Para isso, definiu-se como objetivo geral avaliar se os mesmos estavam preparados tecnicamente para atender com excelência o ascendente segmento do turismo de eventos com a máxima segurança. Para atingir esse objetivo, utilizaram-se os instrumentos de coleta de dados dos tipos bibliográfico e documental e de questionário a fim de afunilar e poder assim conhecer essa modalidade do turismo, diagnosticar as técnicas utilizadas pelos gestores e compreender os riscos potenciais durante o processo de concepção do evento.

De acordo com as entrevistas realizadas com cada profissional, a maioria das pessoas tinha mais de cinco anos de experiência na área de eventos, com formação acadêmica divergente da área de turismo, sendo que apenas $60 \%$ dos entrevistados estavam acostumados a trabalhar para número acima de mil e até cinqüenta mil convidados, e os outros $40 \%$, para quantidade menor.

A realização da pesquisa de campo com profissionais da área pôde diagnosticar a rotina de trabalho dos mesmos e, conseqüentemente, o grau de preocupação com o gerenciamento de riscos. Este estudo veio a confirmar que os gestores de eventos de Brasília não exploram as técnicas de gerenciamento existentes como o Brainstorming, o Brain-writing, o $5 \mathrm{~W} 2 \mathrm{H}$, a Árvore de decisões, o Check-list, entre outras, utilizando somente as mais conhecidas e triviais, sendo que $60 \%$ dos entrevistados utilizam, diariamente, somente o Check-list como base para o planejamento. Visto que essa é uma técnica simples, porém insuficiente para garantir o sucesso do evento, o que sustenta o dado que $30 \%$ dos gestores identificaram que, dentre $5 \%$ e $10 \%$ dos eventos realizados, esses não alcançaram o sucesso esperado. 
A revelação do uso de uma ou duas técnicas específicas de gerenciamento demonstra o interesse parcial pelo assunto. Apesar de todos afirmarem a grande importância da análise e controle dos riscos, o desconhecimento de algumas ferramentas básicas e o desfecho de algumas situações de risco vivenciadas indica um sinal de alerta. Ainda por intermédio das entrevistas realizadas, puderam-se saber quais eram os principais riscos deste mercado, além de estabelecer um paralelo da situação real com as referências teóricas consultadas.

Segundo pesquisa realizada, no ano 2000, pela Universidade George Washington nos Estados Unidos, identificou-se que os fatores de risco mais importantes para 396 profissionais de eventos foram a Venda e Consumo de álcool com 70\%, seguida da Quantidade de pessoas com 61\% e da Capacidade máxima extrapolada com 58\%. Dado que comparado com as entrevistas realizadas com os dez gestores da capital federal, verificou-se que os fatores mais apontados pelos profissionais foram a Comunicação precária e os Organizadores inexperientes, e os demais, a Quantidade de pessoas e o fato de não possuir Plano de execução. Fato importante para a pesquisa que demonstra a inexperiência e falta de qualificação técnica e gerencial das pessoas encarregadas de eventos no DF.

Da análise dos resultados dessas entrevistas, verificou-se que são pessoas tecnicamente não preparadas para a gestão de riscos. Sua experiência permite desenvolver uma grande habilidade em resolver os imprevistos apresentados durante a realização dos eventos. Porém, não desenvolvem uma estratégia estruturada, partem do princípio que problemas não irão ocorrer, pois não vêem o risco como algo a ser trabalhado antes do evento.

Para reduzir o grau de $60 \%$ de improvisação encontrado na entrevista realizada, evidencia-se a necessidade de proporcionar diretrizes básicas por meio da apresentação de técnicas específicas para gerenciar os múltiplos riscos em eventos. O gerenciamento de risco não quer dizer que os imprevistos não existam ou que não irão ocorrer, mas consiste na antecipação dos mesmos a fim de gerenciá-los para evitar perdas de tempo, dinheiro, pessoal, desgaste físico e emocional, além de suprir as necessidades do cliente. 
As etapas propostas sobre gerenciamento de riscos neste trabalho devem ser implementadas no cotidiano dos profissionais, visto que estão cuidadosamente estudadas para serem elaboradas de forma sistemática e com seqüência lógica no planejamento de um mega evento. Para tal fim, propõe-se realizar este procedimento na ordem do Ciclo PDCA em conjunto com a análise SWOT, os quais permitirão ter uma visão global e específica, tanto no externo como no interno do projeto. Esse processo permitirá ter um planejamento cuidadoso e antecipado de cada detalhe envolvido nas diferentes etapas e nos diferentes departamentos relacionados ao evento.

As demais ferramentas apresentadas nas diretrizes do Manual Prático: 0 Brainstorming, o Brain-writing, o 5W2H, a Árvore de decisões, o Check-list, a Probabilidade-impacto, o Diagrama de precedências, a Tabela de atividades, 0 Campo de forças, dentre outras, também são importantes para o desenvolvimento do Plano de ação e constituem o terceiro objetivo especifico. Essas ajudam a qualificar e quantificar a análise interna e externa das situações apresentadas durante o processo de Identificação, Avaliação, Ação, Controle e Correção de riscos. Cada uma dessas ferramentas deve ser adaptada às características do evento e dos organizadores. Mas, todos os eventos têm uma mesma função: produzir um serviço de sucesso e um produto de qualidade com a maior segurança possível aos clientes.

Verificou-se que os parâmetros sobre a prática e o desenvolvimento gerencial realizados nas áreas de eventos da cidade ainda deixam margem para melhorias a serem enfrentadas pelos profissionais da área no que diz respeito à gestão de riscos, conforme resultado da pesquisa de campo realizada.

Outro fato a ser considerado é qualificar tecnicamente os recursos humanos da área. É preciso elevar o padrão de qualidade de prestação desse serviço para poder enfrentar os desafios da competitividade de mercado. É necessário que haja um esforço conjunto entre as empresas do setor e os cursos de carreira no intuito de implementar regulamentações padronizadas para ter profissionais qualificados na área e não só pessoas com conhecimentos empíricos. A experiência é muito importante, porém a qualificação técnica é fundamental para o desempenho e valorização do turismo de eventos. Com o objetivo de competir, nacional e 
internacionalmente, e vender a imagem de uma cidade promotora de eventos, acredita-se que o fundamento gerencial deve ser sólido, constante e profissional.

Em suma, para que Brasília tenha uma imagem de excelência na área de turismo de eventos, é importante se organizar e estabelecer o perfil adequado dos profissionais da área, mas também fazer uso das ferramentas gerenciais existentes. Este é o momento de crescimento do DF no mercado de turismo de eventos e o grande objetivo é aprender, qualificar, planejar e desenvolver a atividade turística com uma visão de futuro, para que, desta forma, haja crescimento na área, no sentido de enfrentar os desafios com competência e profissionalismo. Dessa forma, espera-se que este manual valorize a experiência sólida dos gestores, unindo a teoria e a prática.

Tendo em vista o desenvolvimento do mercado de eventos e a evidência comprovada nesta pesquisa comprovou-se a hipótese de que os gestores de eventos em Brasília não utilizam as suficientes ferramentas que garantem a minimização dos riscos. Em vista da urgência em utilizar ferramentas que proporcionem maior efetividade no gerenciamento de eventos, propõe-se que haja continuidade desta pesquisa, no sentido de que este Manual Prático seja aplicado pelos profissionais de eventos com o objetivo de verificar a praticidade e funcionalidade do mesmo. 


\section{REFERÊNCIAS BIBLIOGRÁFICAS}

ANSARAH, Marília Gomes. Turismo Segmentação de Mercado. São Paulo: Futura, 2004.

CAMPOS, Vicente Falconi. TQC: Controle da Qualidade Total (No Estilo Japonês). Belo Horizonte: Fundação Christiano Ottoni, 1992.

GOLDBLATT, Joe Jeff. Special Events Best Practices in Modern Event Management. 2a Edição. New York: John Wiley, 1997.

HELDMAN, Kim. Gerência de Projetos: Guia para o exame oficial do PMI. Tradução de Teresa Félix. Rio de Janeiro: Elsevier, 2003.

http://brainstorming.com.k/tutorials/definitions. Acesso em: 13 ago. 2005.

http://www.ba.sebrae.com.br. Acesso em: 13 jul. 2005.

http://www.brainwriting.com.k. Acesso em: 13 ago. 2005.

http://www.brasiliaconvention.com.br. Acesso em: 11 jul. 2005.

http://www.creatingminds.org/tools/brainwriting.htm. Acesso em: 13 ago. 2005.

http://www.sc.df.gov.br. Acesso em: 25 jul. 2005.

http://www.setur.df.gov.br. Acesso em: 11 jul. 2005.

http://www.turismo.gov.br. Acesso em: 11 jul. 2005.

http://www.wtoelibrary.org. Acesso em: 25 set. 2005.

MAXIMIANO, Antônio César Amaru. Introdução à Administração. $5^{\mathrm{a}}$ Edição. São Paulo: Atlas, 2000. 
MAXIMIANO, Antônio Cesar Amaru. Introdução à Administração. $6^{a}$ Edição. São Paulo:Atlas, 2004.

PARRA, Domingos. Apresentação de Trabalhos Científicos: Monografia, TCC, Teses e Dissertações. $3^{a}$ Edição. São Paulo: Futura, 2000.

SCHWARTZ, Steve; YAFFE, Joey; GOLDBLATT, Joe; SILVERS, Julia R. Risk Management: Financial, Legal and Ethical Safeguards. The George Washington University Workbook. Washington: School of Business and Public Management, 2000.

SETUR. Plano Estratégico de Desenvolvimento Turístico do Distrito Federal. Brasília, 2005.

SETUR. Plano Estratégico de Turismo - Políticas, Estratégias e Programas (1999-2002). Brasília, 1999. 
APÊNDICE 
APÊNDICE A: Questionário de Gerenciamento de Riscos

\section{QUESTIONÁRIO GERENCIAMENTO DE RISCOS}

Todos os dados coletados para a realização desta Monografia serão utilizados de forma meramente acadêmica. EM NENHUM MOMENTO SERÁ REFERENCIADO O NOME DA EMPRESA QUE RESPONDE AO QUESTIONÁRIO. AS REFERÊNCIAS SERÃO DESCRITAS COMO "ENTREVISTADA “a” ENTREVISTADA "b"...

Nome:

Ocupação:

Instituição:

Data:

1. HÁ QUANTOS ANOS; VOCÊ TRABALHA COMO ORGANIZADOR(A) DE EVENTOS?

( ) MENOS DE $3 \quad$ ( ) DE TRES A CINCO （）MAIS DE CINCO

2. QUAL O MAIOR EVENTO QUE VOCÊ JÁ REALIZOU EM TERMOS DE PÚBLICO?

( ) até 200 pessoas ( ) de 200 a 1000 （）acima de 1000

3. NUMERE, (EM ORDEM DE IMPORTÂNCIA: 1 PARA O DE MAIOR), OS ITENS ABAIXO NO QUE SE REFERE A PRÉ-REQUISITOS PARA A REALIZAÇÃO DE UM EVENTO DE SUCESSO.
( ) Planejar
( ) Executar
( ) Controlar
( ) Corrigir
( ) Dirigir pessoas
( ) Gerenciar imprevistos e riscos 
4. OS EVENTOS GERALMENTE SE DIFEREM UM DOS OUTROS, MANTENDO ALGUNS ASPECTOS EM COMUM. NA SUA ROTINA DE TRABALHO, VOCÊ UTILIZA ALGUMA FERRAMENTA / MÉTODO PARA O PLANEJAMENTO DOS EVENTOS? EM CASO AFIRMATIVO, DESCREVAA. VOCÊ TEM UM ROTEIRO PARA NOS DAR?

5. OS RISCOS DE UM EVENTO SÃO FATOS QUE NÃO PODEM SER ELIMINADOS EM SUA TOTALIDADE. PORÉM, QUAIS OS MAIORES RISCOS QUE VOCÊ, COMO ORGANIZADOR, ENFRENTA NA REALIZAÇÃO DE UM EVENTO? FAVOR ENUMERE, SENDO O NUMERO 1 O MAIS IMPORTANTE:

( ) Comunicação precária

( ) Quantidade de pessoas

( ) Venda e Consumo de álcool

( ) Não ter plano de execução

( ) Atividades perigosas

( ) Condições climáticas

( ) Seguranças inexperientes

( ) Organizadores inexperientes

( ) Capacidade máxima extrapolada

( ) Terciários inexperientes 
6. MARQUE AS TÉCNICAS QUE VOCÊ CONHECE E UTILIZA:

( ) Análise SWOT

( ) Brainstorming

( ) Brain-writing

( ) $5 \mathrm{~W} 2 \mathrm{H}$

( ) Check-list

( ) OUTRAS - CITAR

7. QUAIS TÉCNICAS ACIMA MENCIONADAS SERIAM FERRAMENTAS ÚTEIS NA ORGANIZAÇÃO DE UM EVENTO E PORQUE? CASO NÃO TENHA FAMILIARIDADE COM AS TÉCNICAS, GOSTARIA DE CONHECÊ-LAS E APLICÁ-LAS?

8. INDIQUE O PERCENTUAL DE EVENTOS REALIZADOS POR VOCÊ QUE, NA SUA OPINIÃO, NÃO ALCANÇARAM O SUCESSO QUE VOCÊ ESPERAVA?

( ) MENOS DE 5\%

( ) ENTRE 5\% E 10\%

（） ENTRE 10\% A 30\%

（） DE 30\% A 50\%

( ) MAIS QUE 50\% 
9. NA SUA OPINIÃO, QUAL O MOTIVO DO INSUCESSO?

( ) Falta de planejamento

( ) Dificuldade da equipe

( ) Falta de recursos

( ) Falha no planejamento

( ) Outros

10. VOCÊ REGISTRA EM DOCUMENTO O FEEDBACK DO CLIENTE EM RELAÇÃO AO EVENTO REALIZADO?

( ) Sim

( ) Não

11. AO FINAL DE TODO EVENTO VOCÊ FAZ UM LEVANTAMENTO DOS RESULTADOS COM A SUA EQUIPE?

( ) Sim

( ) Não

12. COMO A EMPRESA SELECIONA A SUA EQUIPE DE TRABALHO?

( ) CLT

( ) Prestador de serviço por evento

13. QUAL É A FREQÜÊNCIA DE REALIZAÇÃO DE TREINAMENTOS NA EQUIPE:

( ) Todo mês

( ) A cada 6 meses

( ) Não fazemos

( ) Outro:citar 
14. QUAL É A FREQÜÊNCIA DE IMPROVISAÇÃO DURANTE A REALIZAÇÃO DE UM EVENTO?

( ) Nunca

( ) Ocasionalmente

( ) Sempre

15. EM EVENTOS, TRABALHA-SE MUITO COM EMPRESAS TERCEIRIZADAS, QUAL É A RELAÇÃO ENTRE AS PARTES?

16. FRENTE A ESSE BOOM DE ABERTURA DE EMPRESAS DE EVENTOS NA CIDADE PELA PRÓPRIA VOCAÇÃO QUE A CAPITAL APRESENTA PARA SEDIAR EVENTOS, MUITAS EMPRESAS ABRIRAM SUAS PORTAS E ESTÃO FUNCIONANDO A TODO O VAPOR. QUAL É O PROCESSO PARA ABERTURA DE UMA EMPRESA COMO ESSA? E A FISCALIZAÇÃO DESSAS? 
17. QUAL FERRAMENTA VOCÊ UTILIZA PARA MINIMIZAR OS RISCOS EM EVENTOS? FAVOR ENUMERE OS ITENS ABAIXO, SENDO O NUMERO UM O QUE VOCÊ CONSIDERA O MAIS IMPORTANTE.

( ) Check list

( ) Manual próprio

( ) Pesquisa

( ) Experiência

( ) Planejamento de cada evento

18. COMO VOCÊ CLASSIFICARIA OS EVENTOS EM BRASÍLIA EM TERMOS DE GERENCIAMENTO DE RISCOS?
( ) Ótimos
( ) Bons
( ) Regulares
( ) Ruins 
ANEXO 
ANEXO A: Listagem de Associados a ABEOC em Brasília

\begin{tabular}{|c|c|c|}
\hline Nome & Contato & Endereço \\
\hline A\&C EVENTOS E PROMOÇÕES LTDA & Ana Alice da Costa e Silva & $\begin{array}{l}\text { Setor Hoteleiro } \\
\text { Sui,Q.06 C4A Si C \& } \\
305\end{array}$ \\
\hline AGENDA EVENTOS E MONTAGENS LTDA & $\begin{array}{l}\text { Maria Auxlliadora Montandon de } \\
\text { Macedo }\end{array}$ & $\begin{array}{l}\text { Srtn Qjo1-Cj.P -Sala } \\
3060\end{array}$ \\
\hline AMARILIS DIVULGAÇÃO LTDA & $\begin{array}{l}\text { Paula Marquez de Amorim } \\
\text { Coutinho }\end{array}$ & $\begin{array}{l}\text { Seps/Sul Eq. } 705 / 905 \\
\text { Sl.53515371539 }\end{array}$ \\
\hline $\begin{array}{l}\text { APLAUSO ORGANIZAÇÃO DE (EVENTOS } \\
\text { LTDA) }\end{array}$ & Marcia de Souza Paula & $\begin{array}{l}\text { Srtn Qd.701 - Cj. C } \\
\text { 124- SI531 BI A }\end{array}$ \\
\hline BBTUR VIAGENS E TURISMO LTDA & Gisele Rodrigues Sampaio Vieira & $\begin{array}{l}\text { Sbs Ed- Sede li Do } \\
\text { Banco Do Brasil-BI B }\end{array}$ \\
\hline BBTUR VIAGENS E TURISMO LTDA (MATRIZ) & Alfredo de Medeiros Brito & $\begin{array}{l}\text { Sbs Q.02-BI. N-11\% } \\
12^{\circ} \text { Andares }\end{array}$ \\
\hline CENTRAL OESTE EXPOSIÇOES LIDA EPP & Alejandro Ruben Parrilha & $\begin{array}{l}\text { Saan Quadra 01 Lt } \\
165\end{array}$ \\
\hline $\begin{array}{l}\text { COMUN!CATO ORGANIZAÇÃO DE } \\
\text { (EVENTOS LTDA) }\end{array}$ & Melissa Matteo Merlo Garcia & $\begin{array}{l}\text { Scs . Qd7 Bl. A - Sala } \\
1412\end{array}$ \\
\hline DIAMOND PROMOÇÕES E EVENTOS LTDA & Carlos Alberto Soares & $\begin{array}{l}\text { Shis Qi } 21 \text { - Cj.06 - } \\
\text { Casa } 16\end{array}$ \\
\hline GOUVEA E EICHLER LTDA & Edgar Luiz Eichler & Scn Q.2 BI. D Sl. 627 \\
\hline IDEAL EVENTOS E PROMOÇÕES LTDA & Cláudia Maldonado & $\begin{array}{llll}\text { Shin Qi. } & 04 & \text { Cj. } & 10 \\
\text { Casa } 21 & & & \end{array}$ \\
\hline LIGHT DE COMUNICAÇÃO E EVENTOS LTDA & Ana Paula Wandalsen & $\begin{array}{l}\text { SRTVS Ed. Embassy } \\
\text { Tower SI. } 321\end{array}$ \\
\hline QUALITY PROMOÇÕES SIC & $\begin{array}{l}\text { Fernando Miranda/Tércio } \\
\text { Sanches-Finan }\end{array}$ & Caixa Postal N' 07921 \\
\hline ROME FEIRAS E PROMOÇÕES LTDA & Rômulo Mendonça de Oliveira & $\begin{array}{l}\text { Shs Q. } 06 \text { Cj. A Bl. C } \\
2^{\circ} \text { Andar Sl. } 220 / 223\end{array}$ \\
\hline $\begin{array}{l}\text { RP LABOR CONSULTORIA DE RELAÇÕES } \\
\text { PUBLICAS LTDA }\end{array}$ & Newton dos Santos Garcia & $\begin{array}{l}\text { Srtvs Qd. } 701 \text { Cj. L Bl. } \\
02 \text { Lj. S160 - Térreo }\end{array}$ \\
\hline VOETUR PROMOÇÕES E EVENTOS LTDA & Caye Milfont & $\begin{array}{l}\text { Setor De Hangares } \\
\text { Lotes } 27 / 28\end{array}$ \\
\hline
\end{tabular}

Fonte: ABEOC Nacional - Listagem de Associados Brasília, 2005. 